Andrews University

Digital Commons @ Andrews University

1999

\title{
Equipping Laity for Ministry in Multi-Church Districts in Brazil
}

Paulo Cesar Nogueira

Andrews University

Follow this and additional works at: https://digitalcommons.andrews.edu/dmin

Part of the Practical Theology Commons

\section{Recommended Citation}

Nogueira, Paulo Cesar, "Equipping Laity for Ministry in Multi-Church Districts in Brazil" (1999).

Professional Dissertations DMin. 711.

https://dx.doi.org/10.32597/dmin/711

https://digitalcommons.andrews.edu/dmin/711

This Project Report is brought to you for free and open access by the Graduate Research at Digital Commons @ Andrews University. It has been accepted for inclusion in Professional Dissertations DMin by an authorized administrator of Digital Commons @ Andrews University. For more information, please contact repository@andrews.edu. 
ABSTRACT

EQUIPPING LAITY FOR MINISTRY IN MULTI-CHURCH

DISTRICTS IN BRAZIL

by

Paulo Cesar Nogueira

Adviser: Nancy Vyhmeister 


\title{
ABSTRACT OF GRADUATE STUDENT RESEARCH \\ Dissertation
}

\author{
Andrews University \\ Seventh-day Adventist Theological Seminary \\ Title: EQUIPPING LAITY FOR MINISTRY IN MULTI-CHURCH \\ DISTRICTS IN BRAZIL \\ Name of rescarcher: Paulo Cesar Nogueira \\ Name and degree of faculty adviser: Nancy Vyhmeister, Ed.D. \\ Date complcted: March 1999
}

\section{Problem}

Most church districts in Brazil are comprised of many churches and companies.

The avcrage load of pastoral care is one pastor for seven congregations. In addition, members have high expectations their pastors and both lack a clear understanding of the role of lay ministry. Thus pastors feel a heavy work load.

\section{Method}

A survey of biblical insights, current literature, and other studies on the priesthood of all believers, lay ministry, and effective pastoral work was undertaken. A program designed to enhance pastoral work in multi-church districts in Brazil was developed. 


\section{Results}

The concept of the priesthood of all believers is outlined in both OT and NT. Every Christian is called to ministry. Not only the paid clergy are responsible for the destiny of the church. The people of God as a whole are called to be involved in ministry.

Since all Christians are priests the church needs to be open to multifaceted ministry where women and men work according to their gifts, talents, and abilities for the growth of Christ's body. The doctrine of the priesthood of all believers and that of spiritual gifts walk hand in hand. On these two pillars the work of the district pastor is built. No program to enhance pastoral work could be developed without due attention to these biblical teaching.

The responsibilities and roles of the district pastor are multiple. Yet, the two indispensable roles are those of spiritual leader and equipper.

Effective pastoral ministry demands total involvement of the laity in the ministry of the church. To this end they need to be motivated and equipped to work in diversified ministries according to their gifts.

The program developed to mobilize laity into ministry consists of two parts. The first involves planning and consists of creating an appropriate climate, clarifying the mission of the specific church, redefining its concept of ministry, and preparing a statement of mission for the church. The second part of the program is the equipping phase. This is achieved through helping members identify and develop their gifts and applying the model of teaching of Jesus and Paul. This way of teaching emphasizes modeling, equipping and mentoring rather than lecturing. 
Andrews University

Seventh-day Adventist Theological Seminary

\title{
EQUIPPING LAITY FOR MINISTRY IN MULTI-CHURCH \\ DISTRICTS IN BRAZIL
}

\author{
A Dissertation \\ Presented in Partial Fulfillment \\ of the Requirements for the Degree \\ Doctor of Ministry
}

by

Paulo Cesar Nogueira

March 1999 
EQUIPPING LAITY FOR MINISTRY IN MULTI-CHURCH

DISTRICTS IN BRAZIL

\author{
A dissertation \\ presented in partial fulfillment \\ of the requirements for the degree \\ Doctor of Ministry
}

by

Paulo Cesar Nogucira

APPROVAL BY THE COMMITTEE:

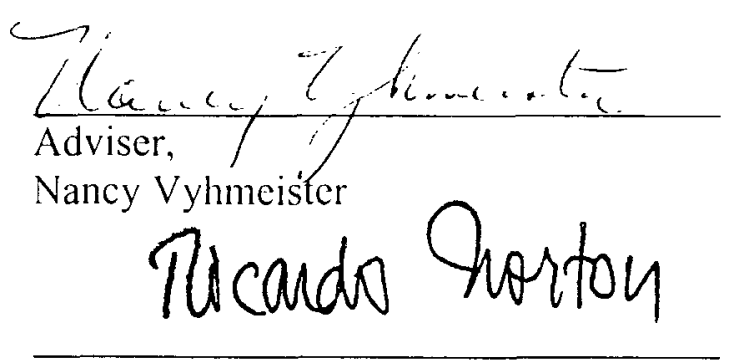

Ricardo Norton
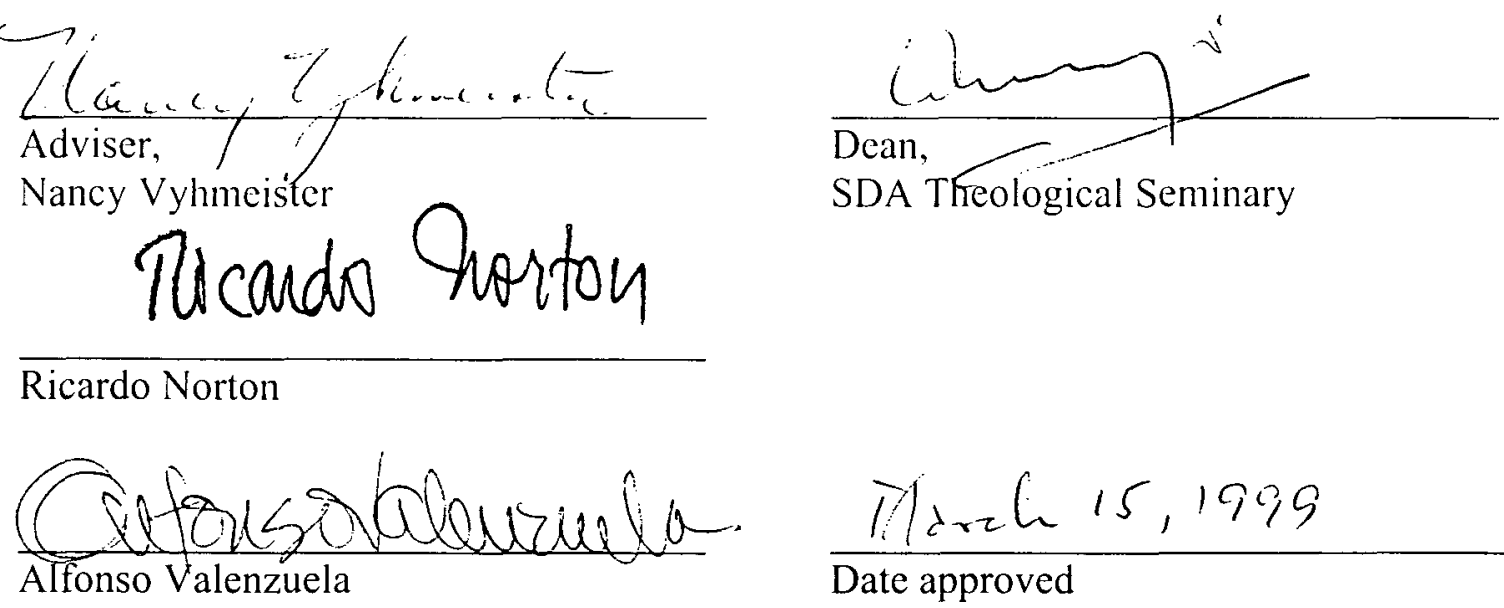


\section{TABLE OF CONTENTS}

LIST OF TABLES $\ldots \ldots \ldots \ldots \ldots \ldots \ldots \ldots \ldots \ldots \ldots \ldots \ldots \ldots \ldots \ldots \ldots \ldots \ldots$

ACKNOWLEDGMENTS $\ldots \ldots \ldots \ldots \ldots \ldots \ldots \ldots \ldots \ldots \ldots$ vii

Chapter

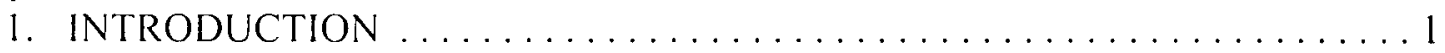

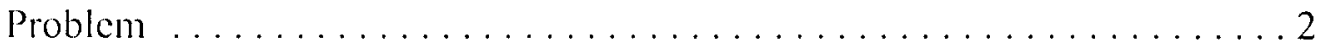

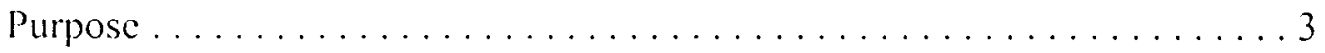

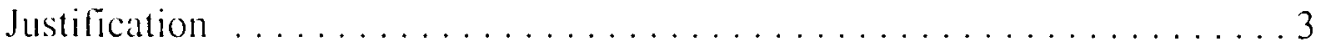

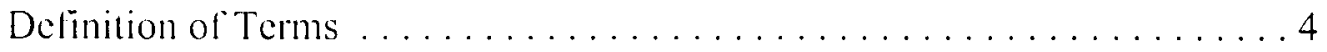

Overview of the Dissertation . . . . . . . . . . . . . . . 4

2. BIBLICAL FOUNDATIONS FOR MINISTRY $\ldots \ldots \ldots \ldots \ldots \ldots \ldots$

Priesthood of All Believers .......................... 7

Old Testament Priesthood $\ldots \ldots \ldots \ldots \ldots \ldots \ldots \ldots \ldots \ldots$

Priesthood in the New Testament $\ldots \ldots \ldots \ldots \ldots \ldots \ldots \ldots$

Every Christian a Priest ........................ 10

Privileges and Responsibilities of Believer Priest . . . . . . . . . . 12

Direct Access to God ........................... 13

Mediation ................................. 4

Sacrifice .................................... 16

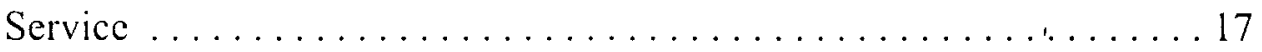

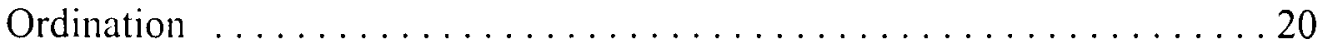

Spiritual Gifts ....................................

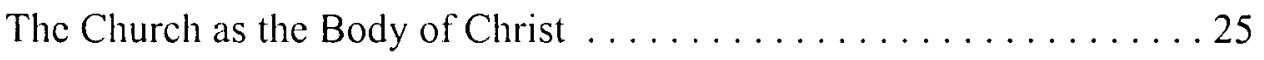

Definition of Spiritual Gifts ...................... 28

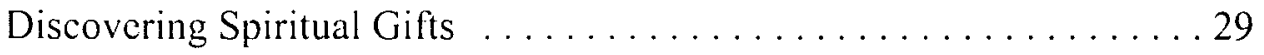

Spiritual Gifts Identified .......................... 30

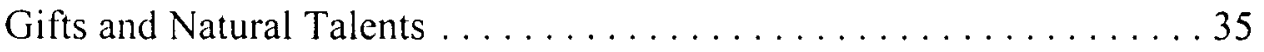

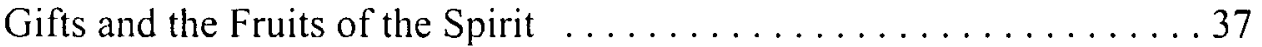

The Function and Purpose of Spiritual Gifts . . . . . . . . . . . . 37

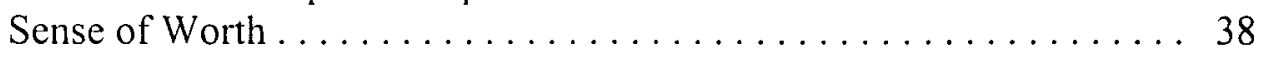

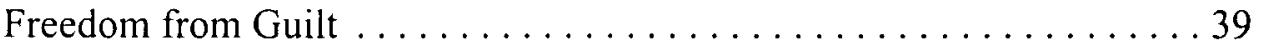

Discouraging Self-Glorification $\ldots \ldots \ldots \ldots \ldots \ldots \ldots \ldots$ 


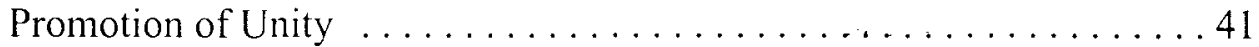

Advancing the Lord's Work .................. 42

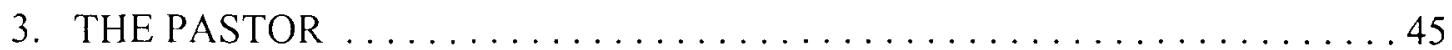

Personal Skills ........................... 45

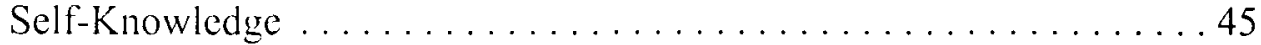

Personal Study and Devotion . . . . . . . . . . . . . . . . 47

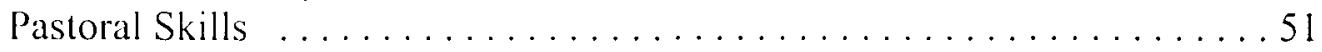

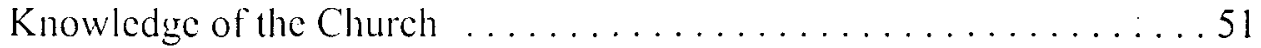

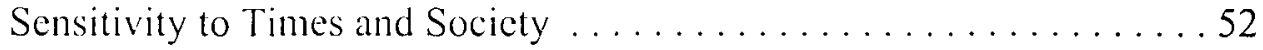

Relational Skills ........................... 54

Time Management Skills . . . . . . . . . . . . . . . . . . 58

Communication Skills ......................661

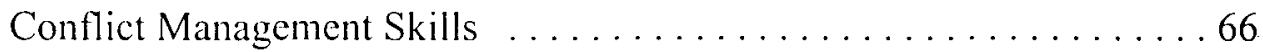

Pastoral Roles . . . . . . . . . . . . . . . . . . . . 68

Spiritual Leader . . . . . . . . . . . . . . . . . . . . . . . . . . 69

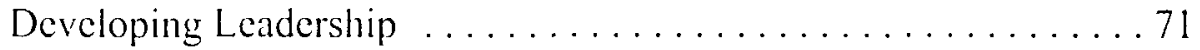

Leadership as Lifestyle ................... 74

Qualities for a Christian Leader . . . . . . . . . . . . . 76

Godly character ................... 76

Vision . . . . . . . . . . . . . . . 78

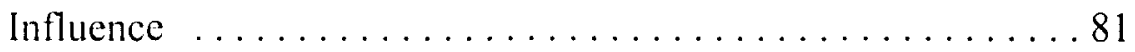

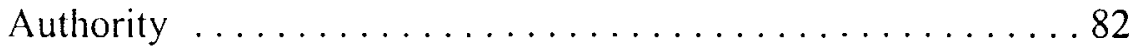

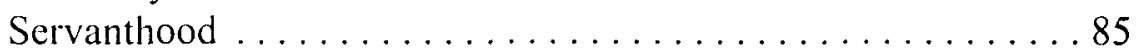

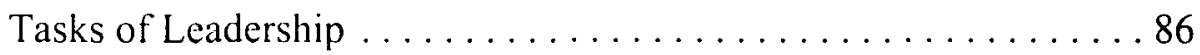

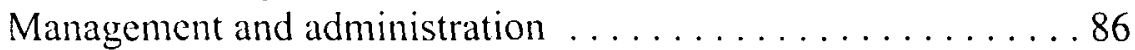

Shepherding . . . . . . . . . . . . . . . . . . 90

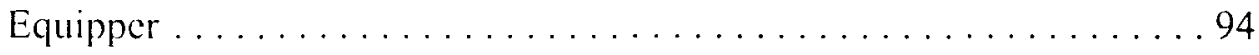

4. THE PROGRAM, PART I: PLANNING PROCESS $\ldots \ldots \ldots \ldots \ldots \ldots \ldots 2$

Mobilize Laity into Ministry . . . . . . . . . . . . . . . . . . . . 102

Effective Pastoral Work and Lay Involvement . . . . . . . . . 103

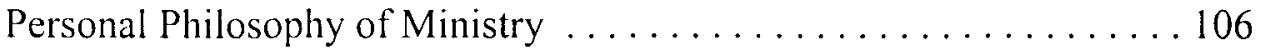

Planning Process to Mobilize Laity into Ministry . . . . . . . . . . . . 108

Create an Appropriate Climate . . . . . . . . . . . . . . 108

Clarify the Purpose and Mission of the Church . . . . . . . . . . . . 109

Redefine the Concept of Ministry ................ 112

Ministry in the Church . . . . . . . . . . . . . . . . 115

Ministry in Daily Life . . . . . . . . . . . . . . . 117

Formulate a Philosophy of Ministry and Statement of Mission . . . . 118 
5. THE PROGRAM, PART II: THE EQUIPPING AND IMPLEMENTATION PROCESS

Presenting Spiritual Gifts . . . . . . . . . . . . . . . . . . . 124

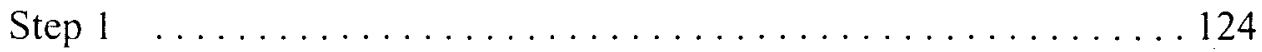

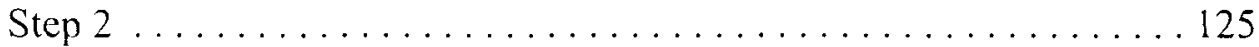

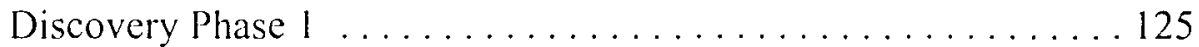

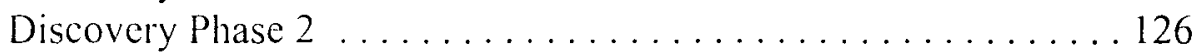

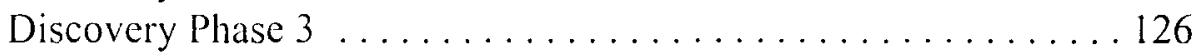

Following Jesus' Model . . . . . . . . . . . . . . . . . . . . . 127

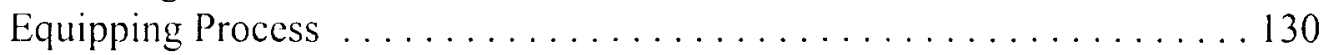

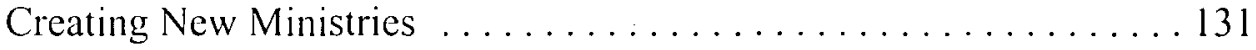

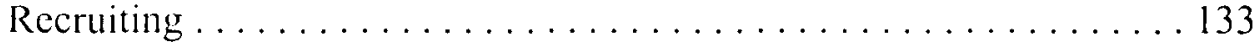

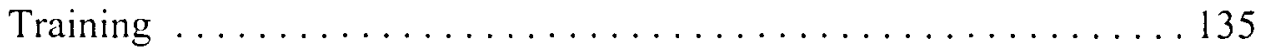

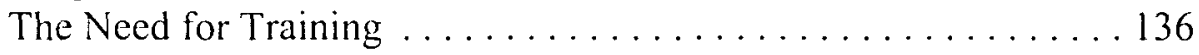

Training in Multi-Church Districts . . . . . . . . . . . 137

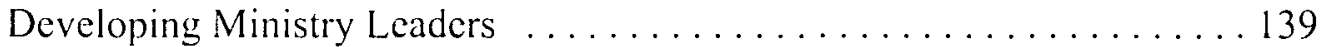

Identifying Potential Leaders . . . . . . . . . . . . . . . . . 140

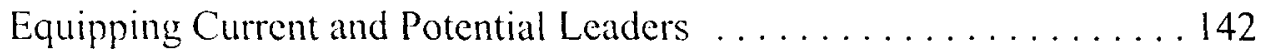

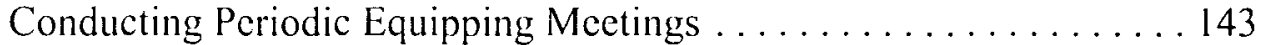

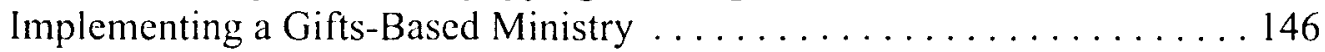

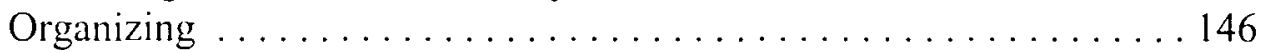

Designing a Placement Process . . . . . . . . . . . . . . . . 147

Ongoing Training and Placement $\ldots \ldots \ldots \ldots \ldots \ldots \ldots \ldots . \ldots \ldots$

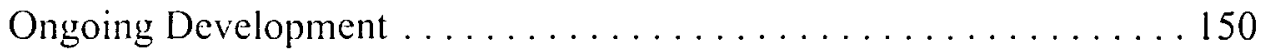

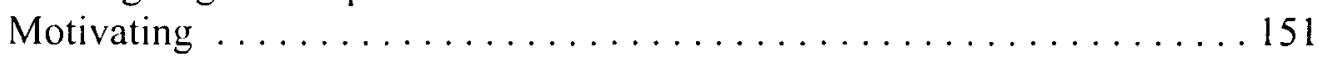

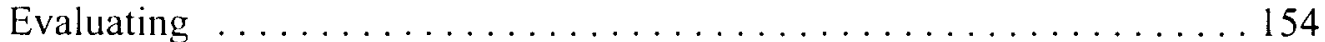

Keeping This Program Alive ....................... 156

The Great Decision ................................. 159

6. SUMMARY, CONCLUSION, AND RECOMMENDATIONS $\ldots \ldots \ldots \ldots 161$

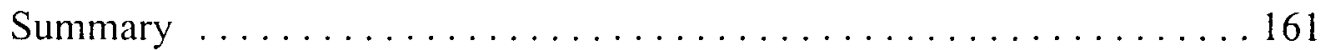

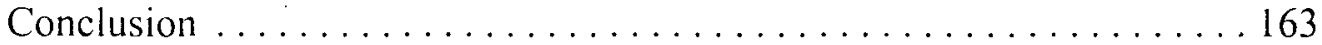

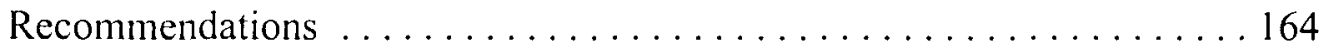

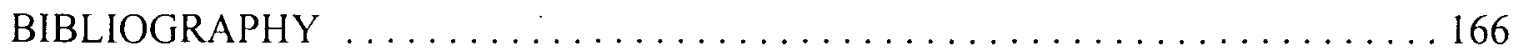

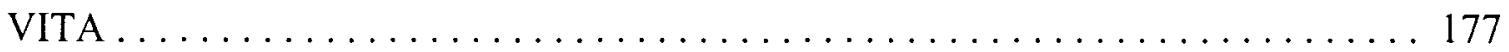




\section{LIST OF TABLES}

1. Comparison of God's Gifts in Paul's Writings ................... 31

2. Gifts and Ministry ........................... 448

3. Two Models of Church . . . . . . . . . . . . . . . . . . . . . . . 159 


\section{ACKNOWLEDGMENTS}

I wish to express my gratitude and appreciation to my adviser, Dr. Nancy Vyhmeister, for her total support and guidance throughout this project; Dr. Ricardo Norton the second adviser, who gave his time and valuable suggestions; and Dr. Alfonso Valenzucla. the third reader, who participated in the oral defense. I also want to thank Dr. Werner Vyhmeister, Dean of the Seminary, who gave me the opportunity to study.

Sincere gratitude is expressed to the Central Brazilian Union, Brazilian Publishing Housc, and Central São Paulo Conference for providing financial support and for arranging a study leave in which to complete the project. Acknowledgment is also due to certain church members of Limeira and Sorocaba for financial support.

I wish to thank my Brazilian friends for their friendship and encouragement.

A special word of appreciation and gratitude is due my lovely wife, Nadia, for her patience, support, and assistance with editorial details and helpful criticism. I also thank my two children, Ellen and Lincoln, for their love and comprehension.

Finally, thanks to God for His guidance and for all the blessings I have received from Him in these three years at Andrews University. What I have achieved is the result of the blessings and mercy of God. To Him be all glory and recognition. 
CHAPTER 1

\section{INTRODUCTION}

Pastoral work in multi-church districts of the Seventh-day Adventist (SDA) church in Brazil has been a major challenge. Success in pastoral work seems an elusive dream to many who start in the ministry with high expectations, only to see them scattered as they face the realities of pastoring large districts. The high expectations from church members and the many tasks to accomplish them have made pastoral work a stressful experience. The time and situation demand that district pastors assign priorities, rethink their roles and the ways they are doing the work of the Lord, and recognize the role of lay ministry in the church.

The greatest problem faced by district pastors is the lack of recognition that all believers are priests and as priests they have a ministry to perform. The pastor's job includes equipping, motivating, and placing members in meaningful ministry according to their gifts, talents, and abilities. The development of lay ministers will result in a network of volunteers who are equipped to do the ministry of the church, working side by side with the pastor to build up the church. 
3

mobilize lay people into ministry based on the biblical concept of the priesthood of all believers and spiritual gifts is a decisive factor for effective and more joyful pastoral work in multi-church districts.

\section{Purpose}

The purpose of this dissertation was to develop a program to enhance pastoral work in multi-church districts in Brazil. Chapters 2 through 5 are intended to be a handbook for training pastors to be equippers of lay ministers.

\section{Justification}

There are 7,625 churches and companies in the SDA church in Brazil, cared for by 880 district pastors. ${ }^{\prime}$ The majority of pastors are assigned to at least eight congregations. Due to high expectations placed upon pastors of multi-church districts (many of them in the first years of their pastoral experience), there is a need for a program designed to help pastors to look after their large districts. For a long time the emphasis has been on what the pastors need to do, but very little on how to do it. Practically nothing has been said about how to implement an effective lay ministry in multi-church districts.

Another great need is a clear understanding of the role of lay ministry in the light of the priesthood of all believers and spiritual gifts. Currently there is openness to exploring and learning in this area. Conference administrators and district pastors have expressed an interest in a program designed to equip laity for ministry in Brazil.

${ }^{1}$ Telephone interview with five Brazilian Union secretaries; statistics from December 1998. 
There is a need and a call for church members in various segments of church life to participate in the work of God.' While not all believers will be called and gifted to minister in leadership positions as pastors, elders, or teachers, ministry is for every member. ${ }^{2}$ Rex Edwards, describing the traits of the early church, says that "the church was not viewed as a musical society which hired the performers and sat back to enjoy the performance. The church was the orchestra in which each member was assigned his part to play." ${ }^{3}$ The members of the church need to be equipped, trained, and recognized, as well as assisted and encouraged, to participate in the ministry of the church.

The pastor and church leaders are responsible for preparing the congregation for productive ministry or service. George Barna says that this is possible only when the pastor helps church members to identify their spiritual gifts, provides opportunities for the individual to utilize those gifts in a significant ministry, and then supports the individual in that ministry. ${ }^{4}$

\section{Problem}

In Brazil most of the pastors work in multi-church districts comprised of six, seven, eight, or more churches and companies. Thus the development of a program to

'Alvin J. Lindgren and Norman Shawchuck, Let My People Go: Empowering Laity for Ministry (Nashville: Abingdon, 1980), 13.

${ }^{2}$ Martin Bobgan and Deidre Bobgan, Competent to Minister: The Biblical Care of Souls (Santa Barbara, CA: East Gate, 1996), 34.

${ }^{3}$ Rex D. Edwards, Every Believer a Minister (Silver Spring, MD: General Conference of SDA, 1995), 8.

${ }^{4}$ George Barna, User Friendly Churches (Ventura, CA: Regal, 1991), 1. 


\section{Definition of Terms}

Church: Although my primary intention is to refer to "church" as the Seventh-day Adventist church, sometimes the word is used in a general sense to refer the whole Christian church.

Companies: Small congregations of members that meet together but are not organized as a church.

Believers: While the term can rightfully be applied to all who claim belief in Christ, in this paper the reference is generally to members of the SDA Church.

Lay ministry, lay leaders, lay people: This term designates those church members who do not hold full-time paid positions in their local church; they are volunteers.

Ministry: This word refers to all kinds of service or offices that build up the church.

Minister: While the word could rightfully apply to a lay member who works for the church, in this paper it usually designates the pastor who receives a salary for his work.

District pastor: A minister or pastor on salary who is in charge of a district; in Brazil a district usually is made up of several churches and companies.

Multi-church districts: The term is used to identify a district containing several churches and companies under the responsibility of a paid pastor.

\section{Overview of the Dissertation}

On my return to Brazil, I hope to use the contents of this dissertation to provide help to overloaded pastors of multi-church districts. From my own experience, from my 
study of the Bible, the writings of Ellen G. White, and a survey of current literature, I have come to the conclusion that the only solution for Brazilian pastors is to empower their church members to carry out ministry in its multiple phases. For that reason, I have prepared this dissertation to serve as resource material for equipping pastors to be themselves equippers. The format I have chosen includes lists and steps; these are not intended for casual reading but to be guidelines for action.

Chapter 2 contains resources to help pastors understand the biblical teachings on the priesthood of all believers and spiritual gifts. In chapter 3 I present the skills a pastor must acquire and the roles he (I use the masculine, since there are no female pastors in my area) must fill. Chapter 4 presents the initial steps that must be taken during the planning stage, when the pastor is preparing the congregation for their new roles. In chapter 5 I lay out the guidelines and suggest the steps to be taken by the pastor and his church to select, train, and equip lay ministry leaders. Chapter 6 contains the summary of the research and the conclusions drawn from it. 


\section{CHAPTER 2}

\section{BIBLICAL FOUNDATIONS FOR MINISTRY}

The biblical foundation for ministry are the doctrine of the priesthood of all believers and that of spiritual gifts. For the enhancement of pastoral work, it is fundamental to understand that every Christian is a priest and has a ministry to perform. These are the topics of this chapter.

The doctrine of the priesthood of all believers and that of spiritual gifts walk hand in hand. On these two pillars the work of district pastors is built. Ricardo Norton says that "in order to develop an effective ministry pastors need to teach and preach the priesthood of all believers." No program to enhance pastoral work could be developed without due attention to these biblical teachings.

The ministry of all believers is laid upon the foundation that every Christian is called to ministry. It is not only the paid clergy who are responsible for the destiny of the church. The people of God as a whole are called to be involved in ministry. It is not a biblical point of view that ministry in the church should be restricted only to ordained ministers. Every member of the church is a Christian minister. Ellen White clearly declares: "The Saviour's commission to the disciples included all believers. It includes

'Ricardo Norton, Class notes for CHMN 664 Equipping Lay Leaders for Church Growth, Andrews University, Berrien Springs, MI, Spring 1998. 
all believers in Christ to the end of time. It is a fatal mistake to suppose that the work of saving souls depends alone on the ordained minister."' She also affirms: "God requires His people to shine as lights in the world. It is not merely the ministers who are required to do this, but every disciple of Christ."

The ministry of all believers is closely related to what is today called discipleship. James Zackrison notes that discipleship involves the application of individual gifts to the development and practice of ministries that match a person's gifts. ${ }^{3}$ The question remains: Is there a solid, biblical basis for interpreting the priesthood of all believers and spiritual gifts as the foundation for church ministry? This chapter is an attempt to reveal such a foundation.

\section{Priesthood of All Believers}

The SDA church believes in the doctrine of the priesthood of all believers. SDAs agree with Protestants in general on the concept of the priesthood of all believers. ${ }^{4}$ Adventists have accepted this teaching as part of their Reformation heritage. ${ }^{5}$ However, 822.

'Ellen G. White, The Desire of Ages (Mountain View, CA: Pacific Press, 1940),

${ }^{2}$ Ellen G. White, Christian Service (Hagerstown, MD: Review and Herald, 1983), 20.

${ }^{3}$ James W. Zackrison, Practical Spiritual Gifts (Boise, ID: Pacific Press, 1996), 12.

${ }^{4}$ SDA Encyclopedia, 1996 ed., s.v. "Priesthood of All Believers."

${ }^{5}$ Alberto Ronald Timm, "Priesthood of Christ and of All Believers according to Martin Luther," Term paper, Andrews University, May 1990, 22. 
it is not merely a Protestant doctrine; "it is in its fullest sense a biblical doctrine (Exod 19:4-6; 1 Pet 2:4-10)."

\section{Old Testament Priesthood}

In the Old Testament (OT) Levitical priesthood, in which Aaron was the high pricst and which was instituted by God (Exod 28:1), one finds the roots of this doctrine. The essential duty of the priest was to represent Israel to God. Priests were in charge of promoting the relationship of men and women with God. At the heart of the Hebrew religion was one's relationship with God; the necessity of maintaining this relationship made the priest's work very important. Raoul Dederen says that priests "attended to the solemn task of approaching God on bchalf of the people. Their functions and responsibilities were evidence of the mercy of God toward His people and of the importance of maintaining an acceptable relationship with God."2

Although God chose and separated the tribe of Levi to perform the duties and specific functions of a priest, it did not exclude Israel as a nation from participating in certain aspects of the priesthood. According to Exod 19:5, 6, the concept of "priest" as one who intercedes or represents men and women before God was extensive to the whole community of the Israelites. God's people were graciously chosen to be a kingdom of priests, standing between God and the people of other nations, to act as mediators of God's grace to the nations of the earth. Dederen declares that "according to Exod 19:5,

$$
\text { 'Raoul Dederen, "The Priesthood of All Believers," Women in Ministry: Biblical }
$$
and Historical Perspectives, ed. Nancy Vyhmeister (Berrien Springs, MI: Andrews University Press, 1998), 25.

${ }^{2}$ Ibid., 12. 
$6, \ldots$ the sons and daughters of Israel were to be priests of God because out of all nations he had chosen them for a special mission of service." The whole nation was to act as mediators of God's grace to the nations of the earth. This mission was committed to every member of the kingdom of priests and not any exclusive class. All people, male and female, old and young, were expected to participate in the ministries of mediationi. ${ }^{2}$ Dederen points out that "Isracl as a nation had been set apart as a priesthood with a meditorial work ..., pointing forward to the coming Priest, Prophet, and King Messiah.".3

\section{Priesthood in the New Testament}

The designation of Israel as God's people is transferred to the Christian church in the New Testament (NT). The believers of the NT are now the spiritual Israel of God (Gal 6:10). God has called the Christian church to represent Him to all nations. What had applied to Israel in the OT is now applied to the Christian church. ${ }^{4}$

The concept of NT priesthood is vividly portrayed in 1 Pet 2:9, 10: "But you are a chosen race, a royal priesthood, a holy nation, God's own people, in order that you may proclaim the mighty acts of him who called you out of darkness into his marvelous light.

'Ibid., 19.

${ }^{2}$ Charles C. Eastwood, The Royal Priesthood of the Faithful: An Investigation of the Doctrine from Biblical Times to the Reformation (Minneapolis, MN: Augsburg, 1963), 4.

${ }^{3}$ Dederen, 19.

${ }^{4}$ Ibid. 
Once you were not a people, but now you are God's people ..." (NRSV). ${ }^{1}$ As in ancient Israel, in the new Israel the laity belong to the people of God. Other passages in the NT confirm the above: 1 Pet 2:5 says that all believers are a "holy priesthood"; Rev 1:5, 6 speaks of Christ who "made us kings and priests"; Rev 5:10 notes that all Christians are called "kings and priests to our God"; and in Rev 20:6 "all will be priests of God and Christ."

\section{Every Christian a Priest}

The next inquiry is: how does onc become a priest? According to Dederen, the concept is that "all born again Christians belong to the priesthood." "Baptism is the sign of our universal call." ${ }^{3}$ Thus, baptism is the anointing and consecration of every bornagain believer as priest of Christ. Martin Luther, the greatest defender and propagator of this biblical teaching, argues that "as a child has its name and rights by heredity from its father, all those who are born as children of this priest [Christ] . . become a priest because Christ Himself has begotten him as a priest." ${ }^{\text {" }}$ H. M. S. Richards enlarges this concept when he states that "if you accept, believe, and practice faith in the Lord Jesus

'The texts quoted in this dissertation are taken from the New Revised Standard Version (NRSV) unless otherwise indicated.

${ }^{2}$ Dederen, 16 .

${ }^{3}$ Ibid., 17.

${ }^{4}$ Martin Luther, Luther's Works (Saint Louis, MO: Concordia, 1955-1986), 13:329. 
Christ, you are a member in His priesthood." Ellen White comments that "all who receive the life of Christ are ordained to work for the salvation of their fellow men..., and all who take upon themselves its sacred vows are thereby pledged to be co-workers with Christ."

In order to understand the magnitude of the implications of being a priest or minister, it is imperative for each believer to have a clear picture of Christ's character, ministry, and mission. The Epistle to the Hebrews adds color to this picture. The author explains that Christ was appointed by God "to act on behalf of men in relation to God" (5:1). His perfect humanity involves oneness with men and women suffering temptation $(2: 9 ; 14-18)$. He lived a perfect life $(7: 28)$. He was paradoxically both Priest and offering $(9: 11,14,26)$; now He "is seated at the right hand of the throne of the majesty in the heavens, a minister of the sanctuary and of the true tabernacle which the Lord erected, and not man" (8:1-2).

Christ's priestly function is in connection with Aaron. "The priesthood of Christ is a continuation and fulfillment of the OT priestly ministry." By virtue of His sacrifice on the cross, Christ has become "the mediator of a new covenant" (Heb 8:6; 9:15; 12:24). Those who accept Christ and make a covenant with Him by baptism become an extension of Christ's spiritual priesthood. Dederen says that "by virtue of our union with Christ we partake of a priesthood that is derived from His. His priestly standing before God is 142.

'H. M. S. Richards, Radio Sermons (Washington, DC: Review and Herald, 1952),

${ }^{2}$ White, Desire of Ages, 822.

${ }^{3}$ Dederen, 14 . 
imputed to every Christian believer." All who are priests are enlisted in a royal and spiritual ministry through which Christ wants to redeem the world. V. Norskov Olsen explains that "through baptism and the endowment of the Holy Spirit the believers have entered into covenant relationship with Jesus Christ, ... their lives are changed into the image of Christ, and they endeavor to minister as He [Jesus] ministered on earth." ${ }^{2}$

NT writers designated members of God's family as kings and priests. In this family everybody is equal before God. There is no Jew or Greek, slave or free, male or female, old or young, because they are all one in Christ (Gal 3:28). Therefore, to be priest in this sense involves "privileges and responsibilities," and also "serious obligations, and a commitment to the priestly work of Christ." ${ }^{4}$

\section{Privileges and Responsibilities of the Believer Priest}

Three important questions may be raised in light of this biblical teaching: What is the relation of the priest's work in the OT times to the priesthood of all believers today? What does God expect from those who lay claim to the scriptural doctrine of the priesthood of believers? Since all believers are ministers, where do paid professional ministers fit today? Is there room for them? According to the Bible teaching, there are

${ }^{1}$ Ibid., 17.

${ }^{2}$ V. Norskov Olsen, Myth and Truth: Church, Priesthood and Ordination (Riverside, CA: Loma Linda University Press, 1990), 41.

${ }^{3}$ Edwards, 8.

${ }^{4}$ Dederen, 17. 
four essential roles in the work of the priest or minister. These explain the meaning of being a minister in the church today.

\section{Direct Access to God}

First, the priest has direct access to God. All Christians enjoy freedom of access to God by virtue of Christ's mediatorial work.' This is the prerogative of every Christian (John 6:37). Olsen says that "the immediate effect of Christ's high priestly office makes it possible for the individual believer to have direct access to the throne of grace (Heb 10:19-20). ${ }^{.2}$ Because Jesus continues to intercede in favor of the fallen race before God, every believer in His name can dare to come to God directly in prayer, with total confidence (Hcb 4:16). The pricsthood of all believers releases and leads every Christian to keep a personal relationship with God. A constant privilege of every Christian it to pray in Christ's name and have access to God (Rom 5:2).

When pastors embrace the biblical truth of the priesthood of all believers, they can focus their ministry in the right direction. The members need to be aware of this privilege to search for God's guidance, maintaining an intimate, open, and deep relationship with Him. Accepting this truth releases church members from excessive or unnecessary dependence on their pastors. Every one needs to pray and to care for his or her own spiritual life.

I"Holy Priesthood," Seventh-day Adventist Bible Commentary (SDABC), ed. Francis D. Nichol, 7 vols. (Washington, DC: Review and Herald, 1980), 7:560.

${ }^{2}$ Olsen, 39-40. 


\section{Mediation}

Second, the priest is to be a mediator interceding in behalf of humans. Beyond the right of praying directly to God in his own behalf, the Christian as a minister has also the duty of interceding for others in prayer, as Abraham did on behalf of the inhabitants of Sodom (Gen 18:22-33). Probably the greatest example of this is the intercessory prayer of Jesus in John 17:1-26. The office of pricst is intercessory and not merely personal in nature. It is to proclaim God's message to others and to pray for others. The priesthood of all believers is a priesthood for others, not merely for oneself. Priesthood cannot honestly be exercised merely in one's own behalf. Priesthood without a people to represent, to pray for, to intercede for with the purpose of reconciling men and women to God is superfluous. When the members of the church commit to this dimension of priesthood, they can understand the mission of the church and get involved in the "ministry of reconciliation" (2 Cor 5:18).

Jesus has laid this burden upon all believers, and they are to represent God and Christ to men (Acts 1:8; Matt 28:19,20). God establishes the priesthood of all believers with the mission of manifesting Christ to the whole world. Believers find an immense satisfaction in being Christ's representatives and taking part in transforming the lives of others.' Ellen White says that "Christ has given to the church a sacred charge. Every member should be a channel through which God can communicate to the world the treasures of His grace." Gottfried Oosterwal emphasizes that "anyone who joins the

'Ibid., 170.

${ }^{2}$ Ellen G.White, The Acts of the Apostles (Boise, ID: Pacific Press, 1989), 600. 
church, therefore, enlists himself as a minister and missionary of Jesus Christ--a coworker in His ministry of salvation unto all the world." In the same vein, Dederen states that "as believer priests, a missionary obligation is placed on all of us. We are to introduce those we encounter to the nearness of God.... We are to see our priesthood in the light of Christ's."

In 2 Cor 5:19, 20, Paul says: "That is, in Christ God was reconciling the world to himself . . and entrusting the message of reconciliation to us. So we are ambassadors for Christ." Not only should the believer be reconciled to God, but it is a part of the Christian priesthood to reconcile men and women to Him. Ellen White affirms: "He [God] expects all, laymen as well as ministers, to take part in the ministry of reconciliation."

In 2 Tim 1:9 and 2 Cor 5:18, Paul reminded believers of their holy call and ministry. On this basis church members are impelled to fulfill their priestly responsibilities. This new priesthood that involves all believers allows the church to become a total force that is equipped and motivated to take the gospel of reconciliation to every living soul on earth that needs divine reconciliation. Thus every believer becomes an instrument of reconciliation "in order that you may proclaim the mighty acts of him who called you out of darkness into his marvelous light" (1 Pet 2:9).

'Gottfried Oosterwal, "Every Member a Minister?" Ministry, February 1980, 5-7.

${ }^{2}$ Dederen, 19.

${ }^{3}$ Ellen G. White, "The Lord's Working Force," The Review and Herald, 11 September 1913, 20. 


\section{Sacrifice}

The third aspect of priesthood is that the priest must offer sacrifice. Whereas Christ offered Himself in sacrifice for our sins forever (Heb 10:12), and there is no possible addition to that, what kind of sacrifice can a Christian offer? Although the Bible does not go into detail on the content and meaning of "spiritual sacrifices," Peter renders a picture of sacrifice focusing on the way we live (1 Pet $1: 15-18 ; 2: 12-15 ; 3: 1-5 ; 4: 19-$ 20). The sacrifices of Christians include their praises (Heb 13:15), confession of Christ's name (Matt 10:32), and total commitment to God (1 Cor 6:31). Christians as "priests" bring their whole life as a sacrifice to God.'

The priesthood is characterized by holiness, by separation from the world, and by complete dedication of the body to God. A Christian is therefore a "royal priest," and God expects His children "to offer spiritual sacrifice acceptable to God through Jesus Christ" (1 Pet 2:5). Whoever tries to follow Christ has a cross to bear (Matt 16:24) and sacrifice to make (Rom 12:1). Being a disciple, says Luther, involves the "offering of one's self to God." It means that each believer will offer his or her own body for others as Christ the high priest offered His body. In this sense, the church does not have a priesthood, but is a priesthood. Luther also notes that the purpose of sacrifice is "honoring and glorifying God and to be a good example for others."3

'Olsen, 40.

${ }^{2}$ Luther, The Misuse of the Mass, Luther's Works, 36:145.

${ }^{3}$ Ibid., 13:333. 
In 1 Pet 2:5 the author presents Christians as "living stones, built into a spiritual house [a temple], in which as priests they offer spiritual sacrifices." Paul probably reaches the high point of the Christian concept of sacrifice when in Rom 12:1 he argues for all Christians to present their "bodies as a living sacrifice, holy and acceptable to God." Dederen concludes that "this sacrificial living is achieved through the power of Christ's resurrection and heavenly intercession."

This third aspect is vital for pastoral work since it challenges all church members to surrender their entire lives to God and His cause. On this basis, they are impelled to fulfill their priestly responsibilities. It also allows the church to become a total force for the advancement of the gospel (Eph 2:19-22).

\section{Service}

The fourth trait of a priest's work is that every minister has a ministry or a service to perform. In the NT the nature of ministry is expressed by words such as "servant," "to serve," and "service," which in their original sense mean "to wait at table" (Luke 17:8). The words "ministry" and "minister" are translated respectively from the Greek diakonia and diakonos, meaning "service" and "servant." In the NT the word "minister" is used for both men and women (Rom 16:1; 1 Cor 3:5; 12:1, 4-7; Eph 6:21; Col 1:7). ${ }^{4}$ In this

'Dederen, 18.

${ }^{2}$ Lawrence O. Richards, Expository Dictionary of Bible Words (Grand Rapids: Zondervan, 1991), s.v. "Servant."

${ }^{3}$ A. Weiser, "Diakoneō," Exegetical Dictionary of the New Testament, ed. Horst Balz and Gerhard Schneider (Grand Rapids: Eerdmans, 1990), 1:302.

${ }^{4}$ Olsen, 66-67. 
sense to be a minister of Christ means to be a servant (diakonos). Jesus, as the perfect priestly model, came to serve. He also said that "whoever desires to become great among you, let him be your servant" (Matt 20:26). In Luke 22:27 He identified Himself as "one who serves." The implication of Christ's words is unmistakable: ministers are to minister in a variety of ministries, always with the purpose of building up the church and leading souls to Jesus. Olsen comments that the nature and essence of church ministry is that of service in the spirit and pattern of Christ. Every structural and vocational aspect of the ministry must have as its soul the covenant of redemption. If the church loses that sense of Christ-ministry it ceases to be church.'

Because this aspect of priesthood has been misunderstood, Christians have misinterpreted the real meaning of being a minister. To be a priest does not even suggest a spirit of arrogance, selfishness, and individualism in terms of access to God, intercessory ministry, office, or position in the church. It certainly does not mean having one's own way to interpret God's word or to work to reach one's own interests. To be a minister implies willingness to minister, to serve. The priesthood of all believers is an offering of self, a mediation for others. It is altruistic. Consequently, those exalted are the ones who serve and not those who are served.

Each member of the body of Christ is a priest with a role and opportunity, if not a duty, to serve the body so that all may be able to serve God and all that belongs to God. Russell Burrill points out that "every member is a priest, then every Christian really is a minister and therefore has a ministry to perform. Once people accept the New Testament

'Ibid., 170. 
teaching of the priesthood of all believers, they must accept the fact that as priests, all believers have a ministry." Therefore, ministry is incumbent on the church as a whole and not only on a special and specialized body of people set apart for the ministry. Ellen White declares that "to every man He [God] has assigned some special line of service, to one God gives a work different from the work that He gives another."2

The high calling of the church is to minister in God's name. This calling is to laity and clergy alike, to all God's people. Indeed, God did not first create clergy and then laity. All are called to be God's ambassadors to minister in His name. ${ }^{3}$ Both clergy and laity are equally accountable before God in terms of their calling and privileges. And this is so because all are God's people, members of His household. In God's family, there are no first- and second-class members. Douglas Johnson endorses the concept that "only when all members of a church can be in ministry is the church a viable and vital organization." 4

This discussion leads to the following question: If every Christian is a priest, is there room in the church for paid professional ministers according to the model adopted by the SDA church around the world? 1993), 27.

'Russell Burrill, Revolution in the Church (Fallbrook, CA: Hart Research Center,

${ }^{2}$ Ellen G. White, Testimonies to Ministers and Gospel Workers (Mountain View, CA: Pacific Press, 1962), 494-495.

${ }^{3}$ Lindgren and Shawchuck, 16.

${ }^{4}$ Douglas W. Johnson, Empowering Lay Volunteers, ed. Lyle E. Schaller (Nashville: Abingdon, 1991), 15. 


\section{Ordination}

Although the NT emphasizes that "all believers are priests," it does not imply that the church has no room for ministers set apart by ordination, or for paid pastoral work by those working full time for the church. The NT church recognized that in the exercise of its corporate life and responsibilities special qualifications were required for the accomplishment of special duties. Dederen states that "God calls some to specific ministries, including positions of leadership or oversight among God's people."' Among lay people "some are called and set aside, ordained to the sole occupation of stewards in the household of God and shepherds of His flock." They are believer priests chosen by God and recognized by the church as endowed with the appropriate gifts for leading God's people in the fulfillment of the commission entrusted to the whole body (Eph 4:11-16). ${ }^{2}$ Russell Staples agrees with Dederen, saying that in the NT "it is clear that in, addition to the variety of gifts given by God through the Holy Spirit (1 Cor 12: 4-13; Eph 4:11-14), the church had a 'set-apart' ministry which was called, commissioned, and

consecrated." Following the same thought Olsen declares that "ordination is considered the legitimate rite and action admitting a person to the official ministry of the church." ${ }^{4}$

'Dederen, 21.

${ }^{2}$ Ibid.

${ }^{3}$ Russell L. Staples, “A Theological Understanding of Ordination," Women in Ministry: Biblical and Historical Perspectives, ed. Nancy Vyhmeister (Berrien Springs, MI: Andrews University Press, 1998), 138.

${ }^{4}$ For more details regarding the biblical foundation for ordination and "professional" ministry, see Olsen, 121-164; Staples, 135-154; and Keith Mattingly, "Laying on of Hands in Ordination," in Women in Ministry: Biblical and Historical Perspectives, 59-74. 
The practice of ordination in the early church, starting with the seven (Acts 6:36), was related to specific gifts already granted by the Spirit, and marked by an act of public acknowledgment and commissioning (Acts 13:1-3; 1 Tim 4:14;2 Tim 1:6). ${ }^{1}$ The English word "ordination" derives from the Latin ordinare meaning to arrange, set in order, or regulate. ${ }^{2}$

The SDA church follows the biblical practice of ordination of gifted members to a "special ministry." While Scripture presents a variety of gifts and ministries, the SDA church recognizes among those three categories of ordination: "that of the gospel minister, the local elder, and the deacon. The church has recognized these ministries as so necessary to its life and mission that it has set apart by ordination those who are called to them.." Although the ordination of ministers was an act instituted by God, the church is of vital importance in ordination since this act is consummated through and by the church, which is empowered to perform this rite. ${ }^{4}$

Although there is room in the church for ordained ministers, of whom some are paid, ordination must not bring distinction between laos and kleros in terms of superior and inferior class, or elevate some Christians above others. No theological distinction is made between the two. Both are ordained by God to minister and neither is exalted over

'Dederen, 22.

${ }^{2}$ Staples, 139.

${ }^{3}$ John W. Fowler, Adventist Pastoral Ministry (Boise, ID: Pacific Press, 1990), 40. ${ }^{4}$ Ibid., $41-43$. 
the other. Therefore, the difference between them is functional and not inherent. ${ }^{1}$ Dederen points out that while some are ordained pastors, dedicated full time to the church and receive salary for such task, "they hold no priesthood different in kind from that which is common to the Lord's people. These ordained believer priests are not placed above the body of Christ, but in it, in the fellowship of all believer priests. The difference is one of degree, not of kind." Enoch de Oliveira warns of the inherent dangers of dividing laos and kleros and points out that Satan seeks to divide the church into two groups: clergy and laypersons, with the purpose of obstructing the triumph of the gospel. ${ }^{3}$

The concept of priesthood of all believers is outlined in both OT and NT. An appropriate understanding of this biblical notion of priesthood of all believers could make a tremendous difference in pastoral work. Church members need to know that they are priests, they are equal before God, and they enter into the ministry of priesthood by baptism. It involves personal relationship with God, into which they enter by offering themselves as a living sacrifice, surrendering their entire life to God, working earnestly in behalf of the lost, and performing ministry or service to build up God's people. The right to be a priest is ours because Christ shared His priesthood with every believer. Jesus is the perfect priest and, inspired by His earthly and heavenly priesthood, each believer

'Gerald Christian, "A Strategy for Revitalization of Congregational Life Through Mission Clarification and the Training of Lay Members in Discipleship" (D.Min. dissertation, Andrews University, Berrien Springs, MI, 1987), 130.

${ }^{2}$ Dederen, 21.

${ }^{3}$ Enoch de Oliveira, "The Universal Priesthood," Ministry, 8 August 1972, 31. 
should work. Dederen concludes: "This truth of priesthood, both of Christ as taught in Hebrews, and of believers as found in 1 Peter and the book of Revelation, is essential to a vigorous life, a mature experience, and a joyous testimony."

Since all Christians are priests, they have to perform a variety of ministries in the church. On this basis the church needs to be open to multifaceted ministry where women and men work side by side with their pastor in various functions and ministries, endowed with gifts granted by the Holy Spirit, according to God's will (Eph 4:11-13; 1 Cor 12:7$10)$.

The acknowledgment of the biblical concept of the priesthood of all believers inevitably leads believers to admit that they need to possess special qualities or attributes that will enable them to effectively work in church ministry. In the NT these attributes are called "Spiritual Gifts."

\section{Spiritual Gifts}

Although the doctrine of spiritual gifts is as ancient as the existence of the church itself, many pastors do not take this doctrine seriously. Ellen White says that "ministers frequently neglect these important branches of the work-health reform, spiritual gifts, systematic benevolence, and the great branches of the missionary work." 2 Paul advises: "Concerning spiritual gifts I do not want you to be ignorant" (1 Cor 12:1). The church in Corinth to which Paul addressed his letter needed instruction on spiritual gifts. Pastors and church members in Brazil need to become better acquainted with this biblical

'Dederen, 26.

${ }^{2}$ Ellen G. White, Evangelism (Washington, DC: Review and Herald, 1974), 343. 
doctrine. Failure to understand this doctrine has brought weakness to the church. C. Peter Wagner comments that "ignorance of spiritual gifts may be a chief cause of retarded church growth today. It also may be at the root of much of the discouragement, insecurity, frustration, and guilt that plague many Christians and curtails their total effectiveness for God." Wagner's assessment is correct. The lack of understanding with regard to spiritual gifts has left the church in a powerless, weakened condition only. Since 1980, the SDA church has included a declaration about spiritual gifts in its statement of twenty-seven fundamental beliefs.

A theology of spiritual gifts is outlined in the Bible, especially in the writings of the Apostle Paul. The NT presents spiritual gifts as operational tools for church ministry. The Holy Spirit assigns a gift or a combination of gifts to individual Christians (1 Cor 12:7). Passages in Rom 12, 1 Cor 12, Eph 4, and 1 Pet 4 allude to a total of twenty-seven spiritual gifts. Undoubtably, as Norton points out, this list is not closed. Other gifts could be added to it. ${ }^{2}$ The Bible does not give a specific definition of spiritual gifts; it simply illustrates how these gifts function.

The doctrine of spiritual gifts is intimately related to Jesus's great commission described in Mark 16:15-16, His plan for reaching the world with the eternal gospel. In order to accomplish this task, the Holy Spirit has to empower the members of the church, bestowing gifts for the fulfillment of their mission. Thus, every priest is equipped by the

\footnotetext{
'C. Peter Wagner, Your Spiritual Gifts Can Help Your Church Grow (Ventura, CA: Regal, 1994), 24.

${ }^{2}$ Norton, Class notes for CHMN 664.
} 
Holy Spirit with gifts needed to build up the church. In this sense spiritual gifts are resources that God bestowed on His church to foster its growth.

After the experience at Pentecost described in Acts 2 and 3, the Holy Spirit became the chief administrator of the church. As one church historian notes, "The early church organization was not centered in office, but in the special gifts of the Spirit." The set of spiritual gifts assigned by the Holy Spirit constitutes the framework for a person's lifelong primary ministry in the church. The degree to which Christians apply these spiritual gifts to work for the Lord depends on their commitment to discipleship and response to the Lord's call.

The Church as the Body of Christ

The doctrine of spiritual gifts can be better understood in Paul's concept of church. He conceived the church as a "body" (1 Cor 12:12, 14-16, 25; Rom 12:4-5). It is precisely in the concept of the church as the body that one finds the deepest sense of the church as an organism. As such, the church is called to grow and to develop. According to Paul the concept of the church as the body of Christ includes the idea of an organism, not simply an organization. John MacArthur notes: "It is not an organization, but a koinonia--a communion, a fellowship of one body and it includes all believers."2

Christ is described in Eph 1:23 and Col 1:18 as the head of the body--the church. Being the head puts Christ in connection with the entire body as a unit, which includes all

'Lars Qualben, A History of the Christian Church (New York: Thomas Nelson and Sons, 1942), 94.

${ }^{2}$ John MacArthur, Jr., The Church, the Body of Christ (Grand Rapids: Zondervan, 1974), 15. 
its members. As head of the church Christ provides vision, knowledge, and direction. In Rom 12:5 Paul declares that the body of Christ operates like the human body. Each part has specific functions working for the well-being of the whole body.

In 1 Cor 12:14-22 Paul again uses the metaphor of the body to demonstrate that all members are important so that the body can function well. Paul's point is that the members of the body of Christ should be as interdependent as are the different parts of the human body. One member cannot say to the other, "I have no need of you" (v. 21). In the church, nobody is superior, on the contrary, the parts of the body which seem to be weaker are indispensable (v. 22). In order for the body to exist as such there must be unity, a functioning together. So the essence of the body is without doubt unity (Eph 4:1$6)$.

As a body, the church of Jesus does not accept that there can be isolated members. In others words, there is no such thing as individual members living in isolation from the rest of the body. No member is the complete body; each is only a part. As a part of the body of Christ, all members serve the others according to their functions and gifts, but no one is independent of the other. Individual church members cannot function effectively by themselves.

Too often the team motif is missing in the church. Many members live in isolation from the rest of body of Christ. Peter Wagner, following the same reasoning, states that "each Christian is a member of the body of Christ, and as such has a particular function to perform just as the ear or the hand does. Furthermore, all are members of the 
same body, so, in a very real sense, all believers need each other." In 1 Cor 12:1, 4-7 Paul speaks about "varieties of ministry, ... but the same spirit works all in all." It means that all gifts are equally important. All gifts are necessary. All gifts come from the same source and all gifts, when used properly, are a blessing for the growth of the body, the church. ${ }^{2}$

Although the Holy Spirit works with individuals, causing them to become children of God, God does not normally save those beings in isolation. That same Spirit brings saved people together. "For in the one Spirit we were all baptized into one body, .. now you are the body of Christ and individually members of it" (1 Cor 12:13, 27). In reality, these two operations of the Spirit, indwelling the individual and putting him/her into the larger body, cannot be separated. Thus, all members of the church have both an individual and a corporate responsibility. Since we have been called to live and grow together as a family (Eph 4:1), we are to "be completely humble and gentle; and patient, bearing with one another in love" (Eph 4:2). We are also to "make every effort to keep the unity of the Spirit through the bond of peace" (Eph 4:3). The growth of the whole body relies on the harmonious working of every organ of the body.

In Eph 4:13 Paul uses strong language to describe the interdependence of the members of the body. Gabriel Fackre notes that "as parts of a body animated by the breath of the same Spirit, they cannot perform their functions without being in living

'Wagner, Your Spiritual Gifts Can Help Your Church Grow, 28.

${ }^{2}$ Don Fortune and Katie Fortune, Discover Your God-Given Gifts (Grand Rapids: Chosen, 1996), 27. 
interrelationships."' Christian Schwarz follows Paul's thought when he affirms that "the biotic principle of interdependence states that the way the individual parts are integrated into a whole system is more important than the parts themselves." All members of the church are not only mutually interlinked, but are equipped for full participation for the growth of the "body." When one envisions the church as a body and each part operating as part of a "structured interdependence," the spiritual gifts constitute a tremendous force to make the body of Christ grow in health.

\section{Definition of Spiritual Gifts}

Gifts are mentioned in both OT and NT as presents given to God and to kings, and from God to man. Several Greek words are used by the NT writers for gift; these include doma, dōea, and charisma. Of these, charisma is the most frequent. This term has different uses: (1) in some passages it means God's gift of salvation; it indicates a grace gift, one bestowed only by God; an example of this usage is found in the statement "the free gift (charisma) of God is eternal life in Christ Jesus our Lord" (Rom 6:23); and (2) in most occurrences in the NT, charisma is God's special endowment or ability of

'Gabriel Fackre, "Christ's Ministry and Ours," in The Laity in Ministry: The Whole People of God for the Whole World, ed. George Peck and John S. Hoffman (Valley Forge, PA: Judson, 1984), 113.

${ }^{2}$ Christian A. Schwarz, Natural Church Development: A Guide to Eight Essential Qualities of Health Churches (Carol Stream, IL: Church Smart Resources, 1996), 66.

${ }^{3}$ Ibid. 
believers for service to the community of faith. When used in this context the term charisma is best translated "spiritual gifts." This paper considers this second use.

Many definitions of spiritual gifts have been given. William Macrae says that spiritual gifts are "a divine endowment of a special ability for service upon a member of the body of Christ." Wagner affirms that a "spiritual gift is a special attribute given by the Holy Spirit to every member of the body of Christ, according to God's grace, for use within the context of the body."

\section{Discovering Spiritual Gifts}

Discovering spiritual gifts is a spiritual process. It involves prayer and commitment to serve God. Discovering particular gifts leads to finding both fulfillment and joy in God's service. Based on Peter Wagner's suggestions, four steps in this important process should be followed:

1. Pray and believe that God will reveal your gifts to you. With a spirit of consecration church members should offer themselves to God and be willing to work for the Lord.

2. Explore and experiment different possibilities. Begin by examining activities that appeal to you.

'Richards, s.v. "Gift/Gifts."

${ }^{2}$ William Macrae, The Dynamic of Spiritual Gifts (Grand Rapids: Zondervan, 1976), 18.

${ }^{3}$ Wagner, Your Spiritual Gifts Can Help Your Church Grow, 28. 
3. Evaluate your feelings and effectiveness. If God has given a gift, it will work and will produce results. If you have the gift of evangelism, people will come to Christ through your ministry.

4. Expect confirmation from the body. Consider how other Christians respond to your efforts. Gifts are for the well-being of the entire body, and no matter how much personal satisfaction the use of the gifts brings, the ultimate question is whether the body is built up. The body need to confirm gifts.'

In this process of discovering gifts and putting them into action the pastor and church leaders have an important role. This will be presented in detail in chapter 4 .

\section{Spiritual Gifts Identified}

Although various biblical writers refer to spiritual gifts, Paul gives the most systematic listing of the Spirit's gifts. (See table 1.) Since the lists are different, one may conclude that none of them is closed. A comparison of the three main lists in Paul's writing identifies many of these gifts. The first section contains two that appear in all three lists; the second group lists those that appear in at least two lists. The final section shows gifts that appear in only one list. 106-127.

'For more details see Wagner, Your Spiritual Gifts Can Help Your Church Grow, 
TABLE 1

COMPARISON OF GOD'S GIFTS IN PAUL'S WRITINGS

\begin{tabular}{lll}
\hline Romans 12 & 1 Corinthians 12 & Ephesians 4 \\
\hline Prophecy & Prophets & Prophets \\
Teaching & Teachers & Pastor-Teachers \\
Service, ministry & Helps, assistance & Apostles \\
& Apostles & Evangelists \\
& Miracles, deeds of power & \\
Mercy, compassion & Healing & \\
Exhortation & Leader & \\
Giving & Faith & \\
& Wisdom & \\
& Knowledge & \\
& Spiritual discernment & \\
& Tongues speaking & \\
& Tongues interpretation & \\
\hline
\end{tabular}

In addition to the gifts in these lists, Paul alludes to others. Some of these are: celibacy (1 Cor 7:7), voluntary poverty (1 Cor 13:3), martyrdom (1 Cor 13:3), hospitality (1 Pet 4:9), exorcism (Acts 8:5-8), intercessory prayer (Acts 12:12), and the gift of being a missionary (Rom 11:13).'

A brief definition or description of these gifts will help church members to recognize whether they have received such gifts. The following list defines in the alphabetical order gifts as they appear in the NRSV.

'Zackrison notes 27 gifts, adding administration, Practical Spiritual Gifts, 56-84. 
1. Apostle: This is a title not normally used in the church today. It means to be "sent out," especially commissioned to represent the church in a broader ministry. Paul traced his apostleship from the time he was ordained and sent out to open work in new areas.

2. Celibacy: This is the ability to remain single and enjoy it; to be unmarried and not suffer undue sexual temptations. Celibates feel they can serve the Lord better that way.

3. Evangelists: The ability to so persuasively present the gospel of Jesus that people are led to become His disciples.

4. Exhortation: This word is derived from the same word that Jesus used for the Comforter, one who comes alongside to encourage. It also refers to the ability to stimulate people to action in the service of God.

5. Exorcism: This special ability that God gives to certain members of the church more than to others permits casting out demons and evil spirits.

6. Faith: A special kind of faith that enables its possessor to see a vision of what God wants done and the unswerving confidence to accomplish it regardless of the obstacles.

7. Giving: The ability to share personal assets with joy and eagerness so that people are helped and God's work advanced.

8. Healing: An ability to call upon the healing power of God in such a way that persons in need receive healing.

9. Helps, Assistance: The gift of helps is the distinctive ability to work with and support other Christians' ministry efforts. 
10. Hospitality: The ability to open one's home graciously so that guests are put at ease and refreshed both physically and spiritually.

11. Intercessory prayer: The ability to pray for extended periods of time on a regular basis and see frequent answers to their prayers.

12. Knowledge: The ability to store and recall a fund of knowledge from God's word to meet the need at hand.

13. Leader, Leadership: The ability to inspire and lead other in various ministries within the body of Christ. This gift is exercised with the attitude of a servant.

14. Martyrdom: The ability to undergo suffering for the faith, even to death, while consistently displaying a joyous and victorious attitude that brings glory to God.

15. Mercy, Compassion: The ability to identify with and comfort or help those who are in trouble or distress. It involves a special sensibility toward persons who are hurting.

16. Miracles. Deeds of power: The ability to perform supernatural acts which glorify God and authenticate the message of salvation to unbelievers. It is sometimes manifested in power encounters with evil spirits.

17. Missionary: Being a missionary involves the ability to minister across cultures.

18. Pastor: The ability to shepherd, counsel, and encourage believers in their walk with Christ and service in the church and community. Also one who enables and equips. 
19. Prophets, Prophecy: A prophet is one who is inspired by God to share God's word. They declare the truth of God, regardless of the consequences, calling people to righteous living.

20. Spiritual discernment: The ability to distinguish between truth and error, and between the influence of evil spirits and good angels.

21. Service, Ministry: A gift that cnables a person to sce practical needs and fill them. Also the willingness to serve under another without any thought of distinction or reward.

22. Teachers, Teaching: The ability to search out, validate, and present truth effectively, to teach God's word clearly.

23. Tongues speaking: The ability to speak in a foreign language not previously learned.

24. Tongues interpretation: The ability to interpret tongues so that others can understand and be edified by the utterance.

25. Voluntary poverty: The special ability to renounce material comfort and luxury and adopt a personal lifestyle equivalent to those living at the poverty level in order to serve God more effectively.

26. Wisdom: The ability to penetrate into a matter, seeing the situation in its large relationships and imparting wise counsel from God's word.

James Zackrison suggests a division of these gifts into four categories.

1. Gifts dealing with outreach and evangelism: Evangelism, miracles, healing, mercy, tongues, and interpretation of tongues, voluntary poverty, and deliverance. These gifts may result in the numerical growth of the church. 
2. Gifts dealing with the spiritual maturity of the church: Prophecy, teaching, knowledge, pastorate, wisdom, faith, and discernment of spirits. These are the gifts that foster spiritual growth, provide discipleship training, and give membership support.

3. Gifts dealing with pastoral care: help, hospitality, intercessory prayer, exhortation or encouragement. These are the gifts to care for and nurture believers in their spiritual, material, emotional, and social needs.

4. Gifts dealing with the administrative functions of the church: leadership, giving, administration, and scrvice. These are gifts fostering the function of the church, such as financial management, maintenance of physical facilities, and membership support.'

\section{Gifts and Natural Talents}

The relation between spiritual gifts and natural talents possessed by a person has arisen. Are spiritual gifts natural talents endowed at birth or are they supernatural powers? It is evident that a supernatural element exists in spiritual gifts, although these may also include ordinary talents and abilities used for spiritual purposes. Both the OT and NT consistently show the Holy Spirit as the source of every good human endowment. All kinds of talents, skills, abilities, and gifts can be used by God to accomplish His purposes. Because of this, "the people of God need to learn to see

'Adapted from Zackrison, Practical Spirit Gifts, 85-90. 
themselves as ministers in every relationship and activity and should see every ability they possess within the framework of God's calling."

Natural talents may be converted by the Lord into spiritual gifts. But sometimes a person is assigned spiritual gifts that are entirely different from natural talents.

Sometimes the two are complementary to each other. For example, singing is a talent. Many non-Christians are good singers. But a Christian who ministers through singing is not only using a talent but also exercising a spiritual gift. ${ }^{2}$

In Zackrison's definition of gifts one finds both natural and supernatural elements: Gift is "a channel through which the Holy Spirit ministers to the church, supernatural gifts of grace given as a stewardship to members, abilities to function in a particular service, divine endowments, unique capacitics, and special attributes." ${ }^{3}$ In this context Ellen White also seems to be inclusive in her use of the terms "gifts," "abilities," and "talents." She uses these words interchangeably. For example, she states that "the talents that Christ entrusts to His church represent especially the gifts and blessings imparted by the Holy Spirit."

'Lawrence O. Richards and Gilbert R. Martin, Lay Ministry: Empowering the People of God (Grand Rapids: Zondervan, 1981), 117.

${ }^{2}$ Eddly Hall and Gary Morsch, The Lay Ministry Revolution (Grand Rapids: Baker, 1995), 65.

${ }^{3}$ Zackrison, Practical Spiritual Gifts, 10.

${ }^{4}$ Ellen G. White, Christ's Object Lessons (Washington, DC: Review and Herald, 1941), 327. 
Gifts and the Fruits of the Spirit

Although the Holy Spirit is the source or origin of all human goodness, spiritual gifts are not the same as the fruit of the Spirit, which is listed in Gal 5:22-23: love, joy, peace, long-suffering, gentleness, goodness, faith, meekness, temperance. The fruit deals mostly with who we are and our motives, while the gifts deal mostly with what we do.' Thus, spiritual gifts cannot work independently of the fruit of the Spirit. Since both are manifestations of the same Spirit they will at all times be in agreement with and complement one another. Charles Conn says that "we must have both the fruit and the gifts, which both complement one another and serve distinct functions in the witness of the church.".2 However, both fruit and gifts are united in purpose and in function. Spiritual gifts vary from person to person, whereas the fruit of the Spirit can be expected as evidence of the Holy Spirit's presence in every Christian's life. Church members need not only be motivated to use their gifts, but also to bear the fruit of the Spirit in their lives. The fruit of the Spirit precedes the gifts in the sense that church members will use their gifts for ministry effectively only if their lives are in harmony with the fruit of Spirit.

\section{The Function and Purpose of Spiritual Gifts}

The concept of the church as the body of Christ can help church members to share in the body's task, to strengthen the church's fellowship, and to extend the church's

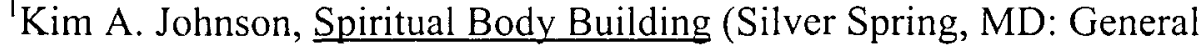
Conference of SDA, 1997), 50.

${ }^{2}$ Charles W. Conn, A Balanced Church (Cleveland, TN: Pathway, 1975), 100-102.
} 
ministries in witnessing. Because every believer is a priest and the Holy Spirit equips each member for service or ministry, one can understand the purpose of spiritual gifts. Every- thing God does and gives has a purpose. Spiritual gifts, as seen in relation to the body of Christ, have a variety of functions and purposes.

\section{Sense of Worth}

The first purpose is to create in the church members the sense of belonging, of value, and to develop spiritual growth. Everyone is granted a gift or gifts (1 Cor 12:4,7). Ellen White states that "spiritual gifts are promised to every believer according to his need for God's work."' She also says that "all men do not receive the same gifts, but to every servant of the Master some gift of the Spirit is promised."2 The Holy Spirit determines which members will receive which gifts (1 Cor 10:11). All these gifts are needed and important to advance the Lord's work. Dederen states: "Since the gifts of the Spirit are granted to all Christian believers, each has a definite ministry, a priesthood, to fulfill." ${ }^{3}$ Each member is a gifted person; each has value. Each is a different part of one body--Jesus' body.

By exercising the spiritual gifts in a diversified ministry in the church, members have a sense of belonging, of worth, and appreciation. This makes a difference in the spiritual life of the believers and consequently in their involvement in the ministry of the church. It creates a sense of dependence on God; therefore, believers become more

\footnotetext{
'White, Desire of Ages, 822.

${ }^{2}$ White, Christ's Object Lessons, 327.

${ }^{3}$ Dederen, 20.
} 
sensitive to the guidance of the Holy Spirit and center on serving Christ's body. Spiritual gifts also help church members to become mature Christians (Eph 4:15) and develop in their lives the "fruit of the Spirit" (Gal 5:20-22). Jesus promised that those who use their gifts will receive more (Matt 25:28-29).

\section{Freedom from Guilt}

Spiritual gifts free members of the church from guilt placed on them by others.

The doctrine of spiritual gifts helps church members to understand their calling and identify ministries for which they are gifted. Norton makes this point clear, saying that it keeps pcople from working in ministries for which they are not gifted or fitted. It helps matching gift and job responsibilities. The church members can thus serve in a zone of comfort and do what they enjoy most.' Kim Johnson also presents an important point on this subject:

Too often well-meaning nominating conmittees use guilt to get people to take on responsibilities in the church. The doctrine of spiritual gifts frees you to say No to without feeling guilty. You may choose to fill in during an emergency, but God only holds you responsible for using what He has given. You do not have all the gifts of the Spirit and are held accountable only for what God has given you. If your gifts are oriented toward working behind the scenes, you should not feel guilty about not being up front. If your gift is hospitality and making new people feel welcome in the church, you should not feel guilty about not going door to door handing out literature. If your gift is administration, you should not feel guilty about not conducting a Revelation Seminar. ${ }^{2}$

'Norton, Class notes for CHMN 664.

${ }^{2}$ Kim Johnson, 43. 
Based on this purpose pastors and church leaders have the responsibility of helping church members to discover and develop their gifts. They will also place them into ministry for which they are gifted.

\section{Discouraging Self-Glorification}

The doctrine of gifts discourages self-glorification. Spiritual gifts are not given for self-enhancement but for the good of the whole "body," to minister to others. The Apostle Peter writes: "As each one has received a special gift, employ it in serving one another" (1 Pet 4:10). Gifts lead church members to care for one another (1 Cor 12:55), serve one another (Gal 5:13), accept one another (Rom 15:7), honor one another (Rom 12:10), bear one another's burdens (Gal 6:2), and encourage one another (1 Thess 5:11). As Christ has become the common possession of all believers, so they are to become the common possession of one another.'

The possession of a particular gift or gifts is a measure of responsibility before God to do the work of kingdom in a sweet, compassionate, and dynamic Christian spirit (Phil 2:5-11). It implies using the gift or gifts to "serve" the body and to glorify the head of the body--Jesus Christ. The assignment of gifts by the Holy Spirt is designed to advance the Lord's work and the gifts are given to glorify Christ, never for selfglorification (1 Cor 12:1-4).

'Glen Greenwalt, "A Priesthood of All Believers: Neither Republic nor Hierarchy," Spectrum 18 (October 1987): 43-49. 


\section{Promotion of Unity}

Spiritual gifts promote "unity" which is indispensable among church members (Eph 4:13). Since each member is part of the total body of Christ, each needing the other, each sensing and recognizing the importance of the other, unity is the natural result (1 Cor 12:25). Paul says that "the body is one" (1 Cor 12:12). In this context, all believers are brought into a relationship with Christ and cach other in the "one body" by the work of the Holy Spirit. In the context of a coordinated body, gifts are seen to be in an interdependent relationship. The variety of gifts is designed to foster unity, not division. When one works with others as a team, cach one contributing with his or her own particular gifts, scrvicc, and cffort, the function of the body and the purpose of the spiritual gifts are accomplished.'

According to Paul the purpose of spiritual gifts is not to divide the church based on more important gifts or less important ones, or on wealth, merit, or status, but exactly the opposite. The intention is to unite members in love, service, and worship. An important element must be considered in order to preserve this unity: Spiritual gifts must be expressed in love. Without love, they can quickly become empty and selfish (1 Cor 13:4-7). Love is, in fact, the dynamic that holds the body together and creates the relational context in which spiritual gifts and ministry can find their full expression. ${ }^{2}$

\footnotetext{
'Richards and Martin, 114.

${ }^{2}$ Ibid., 115 .
} 
Advancing the Lord's Work

In Eph 4: 6-12 the Apostle Paul summarizes the purpose of spiritual gifts: "to equip the saints for the work of ministry, for building up the body of Christ." The gifts in the Bible are given for pragmatic reasons. Spiritual gifts are for the growth of the church. The body needs to grow and work. Monte Sahlin points out that "each member of the body of Christ has been given a special gift for ministry, which, when discovered and utilized properly, builds up the church."

Those talents, abilities, and gifts given to the church belong to the church. The church is set up as a corporate body to do the work of the kingdom by organizing the members' gifts into effective ministries. In this sense, the church has the authority of the Holy Spirit to "administer" the collective gifts of the members. ${ }^{2}$ Wagner says that "the gifts must be developed and put to full use through appropriate channels and structures."3 The exercise of one's gifts brings growth to the church; and growth in Christ will result in the growth of His body--the church.

An understanding of the gifts and the purpose of the gifts mentioned by Paul in this letter in Ephesus, could be a decisive factor for the growth of Christ's body today. The church could be edified, built up in character and in numbers. The church could experience real growth needed so much in Brazil.

${ }^{1}$ Monte Sahlin, Sharing Our Faith with Friends without Losing Either (Washington, DC: Review and Herald, 1990), 175.

${ }^{2}$ Zackrison, "Spiritual Gifts," 11.

${ }^{3}$ C. Peter Wagner, Your Church Can Grow (Glendale, CA: Regal, 1976), 73-74. 
The purpose of spiritual gifts in the Bible is to be a foundation for the creation of a variety of ministries in the church. As the Holy Spirit bestows abilities, talents, and gifts on every believer, the church needs to create diverse ministries to give all believers the opportunity to use their gifts to build up the church. God expects pastors and church leaders to recognize this tremendous potential available in their congregations. They have an important role as mentors, helping members identify their gifts and integrating them into the ministry that is most appropriate for them. This, in time, serves the dual purpose of edifying Christ's body and stretching a bridge to bring the outside community to Christ.

To conclude, priesthood is the title, the prerogative of every believer. It endows each believer with privilege and responsibility. But it is necessary to recognize that each priest has at least one special gift that is needed to build up the church. Spiritual gifts come to confirm and strengthen the gifted persons in their priesthood or ministry.

The doctrines of the priesthood of all believers and of spiritual gifts summon every member to a strong commitment to God and His church. When everyone recognizes that he or she has a role as "priest" and feels that his or her work is a gift from God, it does not matter what type of work it is. That work will help to build a healthy church where every- one accepts regional and individual differences and encourages individuals in their uniqueness, while reminding them that unique gifts also bring unique responsibilities. The priesthood of all believers and spiritual gifts mean giving more selfconfidence and more responsibility to every church member.

Being a priest involves risk--it suggests consequences. The priesthood of all believers, while offering each church member the opportunity to work together with 
gifted people, makes everyone dependent on one another and on God and consequently less dependent on the district pastor. ${ }^{1}$ The role of the pastor is seen through a different lense and the focus of pastoral work changes with the use of this model. This can generate a tremendous difference for effective pastoral work in multi-church districts in Brazil.

The doctrine of spiritual gifts is intimately related to the doctrine of the priesthood of all believers. When one acknowledges one, the other is confirmed. Spiritual gifts are as important to the church as is blood for the life of the body. When it is truly understood that God Himself bestows gifts upon every believer for the purpose of cdifying Christ's body, we are able and have the privilege of recognizing that every believer plays a crucial role as priest or minister in the body of the church.

'Irmtraut Wittenburg, "Europe's Dream: The Priesthood of All Believers," Spectrum 20 (December 1989): 27-28. 


\section{CHAPTER 3}

\section{THE PASTOR}

After working for fifteen years as a district pastor in Brazil, I believe that no program will be effective, regardless of its biblical basis, unless one starts with the pastor. The way pastors see themselves and their job is crucial to their effectiveness in multi-church districts. This chapter deals with the pastor, pastoral skills, and roles.

\section{Personal Skills}

The pastor has two important and sometimes difficult tasks. The first task is to become a fully functioning person; the second, to become a fully competent minister. Due attention to those tasks will make a deep difference in pastoral effectiveness. The first part of this chapter focuses on personal skills. Among the several disciplines that could improve personal skills, self-knowledge, personal study, and devotion may be fundamental for achieving personhood.

\section{Self-Knowledge}

Probably the hardest task for human beings is self-knowledge. Pastors need to know themselves. Every pastor brings together a unique combination of strengths and 
weaknesses. Effective pastors identify their weaknesses and work for improvement. ${ }^{\prime}$ Aubrey Malphurs presents self-knowledge as an important element in effective pastoral work. $^{2}$ When describing traits of effective pastoring, Calvin Miller points out to the pastor: "You will do God no favor if you charge out into the world with no real understanding of who you are. Ignorance about yourself is a self-imposed limitation that will keep your full leadership potential from devcloping."

It is fundamental that pastors realize their own personality, temperament, strengths, gifts, interests, values, attitudes, motivation, and limitations. Honestly, the pastor needs to ask: What kind of person am l? What is my cultural background? What kind of people do I naturally relate to and what kind do I have a harder time understanding?

Pastoral ministry is full of expectations. Self-knowledge could be helpful in dealing with all of these expectations and in enlarging the capability to make right decisions. George Barna presents an important point that may affect the whole life of the pastor and should be a model for pastoral ministry: "The pastor must have the assurance of God's call." The sense of God's call leads one to realize that pastoral ministry is not something one can obtain like an academic degree. Academic training does not create

'James E. Harvey, Who's in Charge? Leadership Skills for Clergy and Others in Ministry (Chicago: Loyola Press, 1996), 20.

${ }^{2}$ Aubrey Malphurs, Values-Driven Leadership (Grand Rapids: Baker, 1996), 134135.

${ }^{3}$ Calvin Miller, The Empowered Leader (Nashville: Broadman and Holman, 1995), 22.

${ }^{4}$ George Barna, The Power of Vision (Ventura, CA: Regal, 1992), 30. 
the pastor; neither does ordination. The true minister for God is not self-called. ${ }^{1}$ Even Jesus Himself was called by God to His ministry (John 6:38). Paul asserted that he was appointed a ministry by God (Col 1:25; 1 Tim 1:12).

Charles Erdman's comment is very appropriate. He says that "one who assumes spiritual oversight in a congregation of Christians should be encouraged and inspired by the belief that the office he fills is of divine origin." When the pastor takes to heart the idea that he is called by God to work in partnership with God and with the members of the church, the vocation becomes greater than any secular career because it is a response "to God's call to partnership." It helps pastors to recognize the importance of their job before God's eycs, in their own self-knowledge, and in realizing God's purpose to their ministry and life.

Personal Study and Devotion

Pastoral ministry and prayer can never be separated. Many times pastors are tempted to neglect prayer. They are too busy; they have too many needs to attend to, too many people to respond to. Then prayer seems a luxury, or it becomes something to do during a free hour, or for a day away from work or on a retreat. ${ }^{4}$ The pastor needs to

${ }^{1}$ General Conference of Seventh-day Adventists, SDA Minister's Manual (Silver Spring, MD: General Conference of Seventh-day Adventists, Ministerial Assn., 1992), 9.

${ }^{2}$ Charles R. Erdman, The Work of the Pastor (Philadelphia: Westminster, 1924), 1.

${ }^{3}$ James W. Fowler, Faith Development and Pastoral Care, Theology and Pastoral Care Series (Philadelphia: Fortress, 1987), 32.

${ }^{4}$ Norman Shawchuck and Gustave Rath, Benchmarks of Quality in the Church: 21 Ways to Continuously Improve the Content of Your Ministry (Nashville: Abingdon, 1994), 14. 
resist the temptation to skip prayer and actively plan to spend daily time alone with God in prayer (Eph 3:20-21) to receive His word (Jer 15:16).

It is important to choose a time and place to open one's heart to God. "Prayer is the raising of the heart and mind to God." The first task of prayer is simply to be with God, to devote time to solitude, silencc, and stillness. "Prayer gives us strength for both personal and professional integrity." It is generally known that although ministers recognize the importance of prayer for effective ministry and personal life, they actively spend little time in prayer. Wagner reports in his own survey of 572 American pastors that the average prayer time was twenty-two minutes per day. ${ }^{3}$ Many pastors would like to spend more time in prayer, but they argue that they have no more time to do so. They allow their schedule to control them. Many times lack of prayer time is due to the lack of time management and not to the nature of the pastoral vocation. Wagner points out that "this means that if we feel we cannot schedule a daily time with God, we need to admit that our relationship to God is not one of our highest personal priorities. If this is true, spiritual disaster could be right around the corner."4

'J. Keith Miller, A Hunger for Healing (San Francisco: Harper, 1992), 181.

${ }^{2}$ Jim Mullins, "Prayer: The Continuing Response," in Maps and Models for Ministry, ed. David Whitelaw (San Diego, CA: Point Loma Press, 1996), 60.

${ }^{3}$ C. Peter Wagner, The Prayer Shield: How to Intercede for Pastors, Christian Leaders, and Others on the Spiritual Front Lines (Ventura, CA: Regal, 1992), 78-79.

${ }^{4}$ Ibid., 84. 
Barry Clair says that "prayer exposes you to who God is, what He wants you to do, and how He wants you to do it." Bill Hybels, in writing about the importance of prayer in a pastor's life and ministry, says that "the most intimate communion with God comes only through prayer." Norman Shawchuck points out that "the first quality God looks for in our ministry is a quality relationship between ourselves and God. The quality of this relationship affects all the other qualities in our work. Without a highquality relationship with God, one will be a trifler in work and ministry."

Praycr plays two important roles in the life of the pastor; the first is presented by Hybels: He says that through prayer God gives us His power. With the power of God, everything can change in one's ministry. Prayer can change circumstances and relationships. It can help pastors to face life's daily struggles and, in fact, it can handle any kind of burden, dilemma, or discouragement in pastoral work. ${ }^{4}$ The second is presented by Wagner: Time with God is essential to strengthen one's love relationship with Him. "All we know about human love relationships tells us that clock time together is essential if the relationship is to grow." Wagner points out that "prayer is the chief way we express our love to God and the chief way we receive God's love for us."

'Barry St. Clair, Leadership: Equipping Young Workers to Lead Students to Maturity in Christ (Wheaton, IL: Victor, 1985), 37.

${ }^{2}$ Bill Hybels, Too Busy Not to Pray (Downers Grove, IL: InterVarsity, 1988), 8.

${ }^{3}$ Shawchuck and Rath, 15.

${ }^{4}$ Hybels, 10-11.

${ }^{5}$ Wagner, The Prayer Shield, 83.

${ }^{6}$ Ibid., 81. 
ultimate goal for spending time alone with God should be to know Him better. Joe Engelkemier says that when pastors care for the depth of their spiritual life God will take care of the breadth of their ministry.' Ellen White warned that "ministers who would labor efficiently for salvation of the soul, must be Bible students and men of prayer. It is a sin to be neglectful of the word while attempting to teach it to others."

Another facet of this personal study and devotion is spending time to study the Scripture. Howard Rice notes that "reading scripture is a way of sensing God's nearness and of receiving a direct word from the Lord for one's daily life." Pastoral ministry consists in a lifetime love with Scripture, a love that produces a passion to know God more deeply. According to James Means, "without the ability to correctly handle the Bible, we have no bread to offer hungry people, no remedy for the poison of sin, and no fortification for the weak." ${ }^{\prime \prime}$ The pastor must be a lifetime student. Jesus' instruction in John 5:39, "Search the Scriptures," and Paul's advice for Timothy, "Preach the word" (2 Tim 4:2), extends to cvery pastor today.

'Joe Engelkemier, Class notes for CHMN 616 Spirituality in Ministry: A Pastor's Prayer Life, Andrews University, Berrien Springs, MI, Fall 1997. 99.

${ }^{2}$ Ellen G. White, Gospel Workers (Washington, DC: Review and Herald, 1915),

${ }^{3}$ Howard Rice, The Pastor as Spiritual Guide (Nashville: Upper Room, 1998), 52.

${ }^{4}$ James E. Means, Effective Pastors for a New Century (Grand Rapids: Baker, 1993), 27. 


\section{Pastoral Skills}

In addition to personal skills, certain other basics skills are indispensable for effective ministry. Pastoral ministry demands that certain skills should be developed if the pastor is willing to pay the price that development involves. Of course, I am limiting my list to the basic skills especially needed by district pastors in Brazil.

\section{Knowledge of the Church}

Due to the nature of pastoral work, the pastor needs to know human beings with the purpose of meeting their needs. Len McMillan reports that the laws of genetics suggest 300 billion possible chromosome combinations, which means that "every person is truly one of a kind." Kent Hunter says that "the whole process that contributes to the formation of human beings is extremely complex and part of the creative miracle that God performs in each and every human being." ${ }^{2}$ Because of this, pastors are faced with congregations made up of people with different temperaments and personalities.

Ellen White endorses the fact that a pastor needs to know the people who come into the church with all sorts of expectations. She encourages pastors to spend time studying different kinds of people with the purpose of satisfying their needs and knowing how to deal judiciously with different minds. ${ }^{3}$ She further declares that "in order to lead souls to Jesus there must be a knowledge of human nature and a study of the human

'Len McMillan, "Feed My Different Sheep," Ministry, January 1997, 18-20.

${ }^{2}$ Kent R. Hunter, Your Church Has Personality (Nashville: Abingdon, 1985), 10.

${ }^{3}$ Ellen G. White, Testimonies for the Church, 9 vols. (Mountain View, CA: Pacific Press, 1948), 4:69. 
mind." The body of Christ is very complex and formed by people of most different characteristics. That is the great challenge of pastoral work.

There are two practical ways to know church members: (1) through a personal relationship with the members, and (2) through the development of a survey system about the members. Of course these both involve taking time with members: visiting, studying, working, teaching, training, equipping, playing, and praying with them. A survey conducted on a regular basis helps pastors to know their members and the overall performance of their churches in a way that enables them to be better prepared to deal with the diverse responses that appear each time the church faces decision making of any consequence. Using this kind of research prepares the pastor to know the members better and to minister to them more adequately.

\section{Sensitivity to Times and Society}

The great social transformation taking place outside the church reflects on the members inside the church. The pastor must be sensitive to the changes in the world, and how they have affected the local community, and even the church. Beyond Bible study, the pastor needs to have access to other sources of information so he has a clear understanding of current trends in society. The pastor needs to be acquainted with the implication of concepts such as "internationalization, urbanization, secularization, technology, individualism, materialism, quality of life, and so on."2 It helps pastors to

'Ibid., 67.

${ }^{2}$ David Fisher, The $21^{\text {st }}$ Century Pastor: A Vision Based on the Ministry of Paul (Grand Rapids: Zondervan, 1996), 63-68. 
know the ministry environment in which they work and to maintain the larger picture of society in this time of deep social changes.

Pastors as Christian leaders cannot afford to be oblivious to their environment. They must address many questions to meet the challenges of a changing world.' They need to understand contemporary trends and the shift of paradigms that have occurred around them with the purpose of becoming more effective in their "business" of spreading the gospel to this generation. ${ }^{2}$ For David Newman, living at this present time calls for innovation so one may assume the risks of trying to preach the gospel in a contemporary and contextual direction. ${ }^{3}$

Brazil is tremendously affected by the social changes that have occurred in other parts of the world as well as within the country. Social change has affected the lives of families and church members. Consequently, pastors need to be prepared to handle a variety of situations. Barna writes that "effective ministry in the years ahead will be quite different from meaningful ministry today. Change is occurring that quickly. And we must develop intelligent and effective responses, in service to Christ, just as rapidly."

'Phillip V. Lewis, Transformational Leadership: A New Model for Total Church Involvement (Nashville: Broadman and Holman, 1996), 5.

${ }^{2}$ Walter Douglas, Class notes for CHIS 688 Contemporary Trends, Andrews University, Berrien Springs, MI, Spring 1998.

${ }^{3}$ David Newman, Class notes for CHMN 623 Innovative Evangelism, Andrews University, Berrien Springs, MI, August 1998.

${ }^{4}$ George Barna, The Frog in the Kettle (Ventura, CA: Regal, 1990), 27. 


\section{Relational Skills}

The foundation of effective pastoral ministry is the ability to sustain lasting, growing relationships.' This is one of the most important skills for pastoral work. The job of the pastor involves working to affirm, to lead, and to motivate people. In short, it is to build up people. John Maxwell, writing about the importance of pastors' developing relational skills, states that "the basis of life is people and how they relate to each other. Our success, fulfillment, and happiness depend upon our ability to relate effectively. The best way to become a person that others are drawn to is developing qualities that others are attracted to."

The ability to relate to people, to develop relationships, to use effective skills in conflict management, and to facilitate making people feel important and instrumental in accomplishing worthwhile goals is an important aspect of pastoral work. By personal example, preaching, and teaching, the pastor needs to promote healthy relationships. Pastors who fail in their ministrics usually do so because of deteriorated relationships with their family, community, church members, and church administrators. Healthy relationships in these four areas of life precede effective ministry. ${ }^{3}$

In the secular world, 80 percent of people who fail at work do so because they do not relate well to other people. ${ }^{4}$ James Autry says that in the business world, "no matter

\footnotetext{
'Jeffrey Arnold, Seven Traits of a Successful Leader (Colorado Springs, CO: NavPress, 1997), 12.

${ }^{2}$ John C. Maxwell, Be a People Person (Wheaton, IL: Victor, 1989), 9.

${ }^{3}$ Means, Effective Pastors for a New Century, 200.

${ }^{4}$ Ibid.
} 
what anyone tells you, when you lose business, it's almost always a relationship problem." Similarly, in pastoral work, the most basic cause of ineffectiveness and failure is an inability to build and sustain relationships, especially with church leaders. The pastor needs to be a model of sincere and transparent relationships. Without relational skills and healthy relationships, pastors set themselves up for failure in ministry.

To build and sustain relationships, pastors must know themselves. Means points out that failure to know and understand self prevents one from knowing and understanding others or from self-disclosing to others. Pastors must cvaluate their own inner world to discover traits that can thwart the development of more productive relationships. $^{2}$

Quite often pastors have a tendency to like certain people and develop relationships with those who reinforce their good characteristics. At the same time they avoid people who draw attention to their weakness. Means makes this point very clearly: "Early in the life, when we learn that we cannot talk openly about certain inner realities, we erect walls and wear masks to screen our worst traits from public view, and eventually we may come to repress the truth about ourselves." Many pastors, especially those who are dealing with such ministerial doubts, ask such questions as: How much

'James A. Autry, Love and Profit: The Art of Caring Leadership (New York: Morrow, 1991), 40.

${ }^{2}$ Means, Effective Pastors for a New Century, 202.

${ }^{3}$ Ibid. 
should I get involved? To what degree should pastors keep professional distance or promote interpersonal warmth and affection?

Although a pastor can learn from the experience of older pastors, certain facets of ministry are learned only with time and experience. As every church is formed by people with different personality types and with different levels of maturity, the measure of a pastor's involvement is related to his degree maturity, education, and personality type. At the same time pastors must develop interpersonal relationships characterized by affection, transparency, vulnerability, and warmth. They must be aware of the need to maintain their respect and to avoid any form of intimacy. Wise pastors who study and examine human nature and tendencies can carefully measure the degree of transparency and intimacy that should characterize their ministry. This will depend on the degree of spiritual and emotional maturity of the people involved.

Some practical aspects for developing meaningful relationships with church members are as follows:

1. Accept the fact that no matter how hard a pastor tries and despite one's best efforts, the pastor will not be able to avoid every obstacle and be successful in every relationship. Paul states, "If it is possible, as far as it depends on you, live at peace with everyone" (Rom 12:18). The pastor should do everything to preserve harmony and healthy relationships--of course, without compromising biblical principles and one's own convictions. However, the pastor needs to be prepared to accept the reality that harmony is not always possible.

2. Follow Jesus' advice in Matt 7:12: "Therefore, whatever you want men to do to you, do also to them." Even when following Jesus' advice, the pastor will not be able 
to wipe out every conflict from his ministry but will certainly have achieved a keystone principle in interpersonal relationships.

3. Accept criticism and know when to ignore it. Probably every church has a certain kind of member who likes to give the pastor a hard time. I learned in my first district that a pastor cannot possibly meet everybody's expectations, and some people let us know it. No one in ministry escapes criticism, bruises, injustices, incomprehension, or worse. How the pastors act when faced with criticism or injustice determines the quality of their relationships and ministerial effectiveness. Often, following Jesus' instruction in Matt 18:15, "if another member of the church sins against you, go and point out the fault when the two of you are alone," is the best way to clarify or to explain some points of pastoral life and work.

Marshall Shelley, when writing about the way pastors should receive criticism of their ministry, points out that "often the greatest damage is not done by the dragons (critics) themselves, but by the reactions they provoke in others. When attacked by dragons, our normal response is to become upset or defensive, and when we feel threatened, we usually wind up dousing the fire with gasoline." The key for pastoral relationship is to avoid the confrontational style, i.e., "an eye for an eye and a tooth for a tooth" (Matt 6:38), and the use of defensiveness. Pastors who are nonconfrontational and nondefensive have a more productive and satisfying pastoral ministry. This does not mean that the pastor should ignore all criticism, but it does mean that he should evaluate the source of complaints and decide how much attention to give it.

'Marshall Shelley, Well-Intentioned Dragons: Ministering to Problem People in the Church, Leadership Library, 1. (Carol Stream, IL: Christianity Today, 1985), 120. 
Pastors need to evaluate the constructive value of criticism. If they are wrong, the best attitude is to recognize their error and, with humble spirit and God's power, fix it. On the other hand, the proper attitude is not to take any criticism too seriously and continue to work. Paul is an example on this latter advice. He says: "Am I now trying to win the approval of men, or of God? Or am I trying to please men? If I were still trying to please men, I would not be a servant of Christ" (Gal l:10).

\section{Time Management Skills}

Solomon states there is a "time for every matter under heaven" (Eccl 3:1-9). This declaration may be a challenge to district pastors in Brazil who often do not find time to perform their regular responsibilities. There are so many things to be done and time seems too short. Although pastors have the same allotment of minutes in a day, they need to discipline themselves to effectively use those minutes. Effective pastoral work depends in great measure on the wise use of time. Norton says that "pastors must learn to manage their time." Samuel Proctor and Gardner Taylor say that "an effective pastor must be able to make realistic time assessments. Many pastors make claims about their time, but they may be busy with trivialities.", How should the pastor balance preaching, teaching, counseling, training, visiting, evangelizing, disciplining, traveling, administrating, and the dozen or so other responsibilities? How should the pastor's work-week be divided so time is used profitably?

\footnotetext{
${ }^{1}$ Ricardo Norton, Class notes for CHMN 638 Seminar in Leadership, Andrews University, Berrien Springs, MI, Fall 1997.

${ }^{2}$ Samuel D. Proctor and Gardner C. Taylor, We Have This Ministry: The Heart of the Pastor's Vocation (Valley Forge, PA: Judson, 1996), 55.
} 
Time management is largely a matter of having the wisdom to determine when to say yes and when to say no. Then one must make the commitment to work on the 'yes' as efficiently as possible all the way to completion and with a feeling of deep personal satisfaction. Time management for pastors is stewardship of God's time.' Lowell Erdahl makes this important point: "God has not given us enough time to do everything everybody wants us to do or even enough time to do every thing we would like to do. But God has given us enough time to do what God wants us to do."2

To be more efficient and to survive under pressure, pastors have to organize their ministry in a simple but practical way. The pastor can use three charts to assign priorities: important, very important, priority. Important things should be done; very important things need to be done; priorities must be done today, this week, and so on. Pastors must list their activities in these categories and discipline themselves to stay away from the bondage of immediate gratification without taking into consideration their time priorities. Scheduling is an efficient tool to help pastors force themselves to prioritize. Pastoral work in multi-church districts requires pastors to build their ministry on priorities.

Lowell Erdahl makes another important point by saying that the pastor must distinguish between the urgent and the important. Things that are urgent but not important often crowd out things that are important but not urgent. Pastors sometimes

'Skip MacCarty, Class outline for EDRE 676 Topics Family Ethics: Family Life Conference, "Using Your Time to Accomplish What's Most Important," Andrews University, Berrien Springs, MI, August 1996, 4.

${ }^{2}$ Lowell O. Erdahl, 10 Habits for Effective Ministry (Minneapolis: Augsburg, 1996), 78. 
allow themselves to be distracted by the details of a hundred urgencies. Each has some minimal value, but even when added together they are not of great importance.

"Nevertheless, they fill our hours and days and keep us from vital work we are called to do. Because they give us an excuse to put off significant and difficult things we don't like to do, we may even welcome such distractions."' Erdahl also suggests that it is helpful to use an A, B, C system. Things that are urgent and important are class $\mathrm{A}$ priorities. Things that are important but not immediately urgent are in category $\mathrm{B}$, and those that are neither urgent nor very important fall into category $\mathrm{C}^{2}{ }^{2}$

Peter Drucker discusses time management in pastoral work by saying to pastors: "You must learn to set objectives for yourself and for various major tasks you think you should be doing.".3 Time management involves following some important steps: (1) formulate a clear statement of their purpose; (2) list priorities; and (3) set challenging goals and objectives. This can be accomplished in short-term, mid-term, and long-term goals. Objectives give the pastor direction and destination. In order to set goals and objectives, pastors need to ask themselves: What are the priorities in my own life and ministry that, if done well, will really make a difference?

An important skill that pastors need to develop in terms of time management is to delegate everything that can be done by church members. This delegation helps the pastor avoid exhaustion and fatigue in daily life. Calvin Miller suggests three steps in

'Ibid., 79-80.

${ }^{2}$ Ibid.

${ }^{3}$ Peter F. Drucker, "Responsibility to Self," in Leadership Handbook of Management and Administration, ed. James D. Berkley (Grand Rapids: Baker, 1994), 80. 
the task of delegation: (1) Listen to everyone; (2) Adjust your management style as you learn; (3) Delegate tasks and give all the glory of achievement to those who did the work. ${ }^{\prime}$

Many pastors who work in multi-church districts have a hard time finding time for their families. Time management also involves the family. Time together is an indispensable element to keep the family's relationship. David Faust points out that "the Bible tells husbands to love their wives as Christ loved the church, not to love the church at the expense of their wives and children."2 He also presents some suggestions on how pastors should separate quality time for their families: (1) Learn to say no more often without fecling guilty or worrying what others will think; (2) Make dates or special nights out more of a priority; (3) Take short weekend trips just for fun and attend a different church where you and your family just sit together; (4) Change your workoriented mind- set to allow more room for being yourself and enjoying yourself more as pastor, husband, and father. ${ }^{3}$

\section{Communication Skills}

Communication is the most important skill in life. ${ }^{4}$ Pastors cannot build vital, meaningful ministry and cannot lead the church competently unless they communicate 1994), 140.

'Miller, 177-178.

${ }^{2}$ David Faust, Growing Churches, Growing Leaders (Joplin, MO: College Press, ${ }^{3}$ Ibid., 139.

${ }^{4}$ Stephen R. Covey, The Seven Habits of Highly Effective People (New York: A Fireside Book, 1990), 237. 
well. ' Maxwell points out that the pastor "must never underestimate the importance of communication. Without the ability to communicate, a leader [pastor] cannot effectively cast his vision and call his people to act on that vision. A leader is not capable of reaching his potential without effective communication skills."

Communication is defined as a positive interaction. It is the art or skill of listening carefully and expressing onesclf in such a way that one is readily and clearly understood. Good communicators are willing to listen to what a person has to say, to focus on the response of the person they are talking to, to read body language, and to make eye contact with the person they are speaking to. ${ }^{3}$

Stephen Covey presents four basic forms of communication: "reading, writing, speaking, and listening." The ability to do them well is absolutely critical in pastoral work. Covey further declares: "You have spent years learning how to read and write, years learning how to speak." Then he asks, "but what about listening?" Means notes: "Leadership involves effective communication, and effective communication begins with listening." If the pastor wants to interact effectively with a person he needs to listen, to seek first to understand, and then to be understood. Being an empathetic listener

${ }^{1}$ Means, Effective Pastors for a New Century, 31.

${ }^{2} J o h n$ C. Maxwell, Developing the Leaders around You (Nashville: Thomas Nelson, 1995), 57.

${ }^{3}$ Ibid., 58-59.

${ }^{4}$ Covey, 237.

${ }^{5}$ Ibid., 238. 63.

${ }^{6}$ James E. Means, Leadership in Christian Ministry (Grand Rapids: Baker, 1990), 
involves the ability to listen to and to understand people and to learn to work together cooperatively. This will accomplish more results than doing the work alone.'

Of particular importance in pastoral ministry is pulpit communication--preaching and teaching. "No single action of pastors attracts or repels people so directly as the pulpit ministry." Bill Hull points out that "if the pastors are going to lead the church of the twenty-first century, they must begin with their sermons." ${ }^{\prime 4}$ Church members come to the church to find hope, forgiveness, comfort, and nurturing for their souls with God's word. Visitors come to the church hoping for spiritual nourishment and will not return if the sermon is boring and irrelevant. Every time the pastor preaches is an opportunity to bring others to a new life in Christ. Pastors need to share the gospel message with the expectation that the Holy Spirit will use it to create new life in their listeners. ${ }^{5}$

Since preaching and teaching are so important, pastors must dedicate time to prepare to preach or teach. Bruce Mawhinney names two important ingredients for effective pulpit communication: the sermon based on the word of God and due preparation. ${ }^{6}$ The sermon needs to be founded in God's word. There is a tendency to preach from other sources, using what Paul called "the persuasive words of man's

${ }^{\text {Ibid., }} 53$.

${ }^{2}$ Means, Effective Pastors for a New Century, 32.

${ }^{3}$ Ibid., 189.

${ }^{4}$ Bill Hull, Seven Steps to Transform Your Church (Grand Rapids: Fleming H. Revell, 1993), 83.

${ }^{5}$ Erdahl, 61-62.

${ }^{6}$ Bruce Mawhinney, Preaching with Freshness (Grand Rapids: Kregel, 1997), 57. 
wisdom" (1 Cor 2:4). The pulpit without the word of God and exaltation of Christ becomes mere entertainment. To preach well the word of God requires preparation. ${ }^{1}$

District pastors in Brazil are inundated with many duties, serving both the church and the community. It is easy for them to become so absorbed with many things to do that preparation and meditation are forgotten. They need time for meditation, personal prayer, and wrestling with passages of Scripture. It can become a habit for the preacher to begin his sermon preparation on Friday evening. Preaching dare not become a sideline. One of the greatest needs in Brazil is for more consecrated men and better preachers--able communicators of the word.

Reynolds Hoffman advises preachers: Plan "your preaching a year in advance [to] add comprehensiveness and depth to your pulpit ministry. It will give direction to your study and help to eliminate repetition." Having a sermonic year and thematic preaching helps the pastor to prepare better and can provide an inspirational diet for the church. Again, preparation is the key for effective preaching.

Beyond careful preparation, two basics aspects must be considered by every pastor who wants to become an effective communicator of the word of God. First, the sermon must be relevant to the needs of the people. Earl Hunt declares that the church

'Paul R. Smith, "The Methods of Selected British Pastors Evaluated in the Light of the New Testament and Ellen G. White for Their Usefulness to the Seventh-day Adventist Church" (D.Min. dissertation, Andrews University, Berrien Springs, MI, 1992), 62.

${ }^{2}$ Reynolds Hoffman, "Planning a Sermonic Year," Ministry, December 1978, 8. 
becomes irrelevant when the sermon does not provide for the real needs of people.' Paul Yonggi Cho, presently the pastor of the largest church in the world, says that he tries desperately to relate all his sermons to the needs of the people. ${ }^{2}$ Effective preaching takes into account the needs of the congregation and tries to present the word of God as a solution to their needs. When the sermon meets the needs of people, it inspires and moves them to make the right decisions. The pastor has the sacred responsibility of presenting the word of God in such a way that animates, inspires, persuades, elevates, inspires, and impels the congregation to follow God's word. Every time the word of God is preached, there is an opportunity to change human lives.

Second, the sermon type makes a difference in the way people respond. I suggest that pastors in Brazil preach expository sermons. Simply defined, an expository sermon is one that is based on the exposition of three or more verses of scripture. If the passage discussed is shorter than that, the sermon is usually called textual. Sometimes the unit of Scripture is a paragraph, at other times a chapter, occasionally an entire book. In the expository sermon's strictest form, the structure follows the order of the ideas in the passage. Presumably, expository preachers begin preparing their sermons by choosing a passage of Scripture and studying it in depth. ${ }^{3}$

'Earl G. Hunt, Jr., Evangelism for a New Century (Nashville: Discipleship Resources, 1994), 35.

${ }^{2}$ Paul Yonggi Cho, Successful Home Cell Groups (Plainfield, NJ: Logos International, 1981), 149. $1991,25$.

${ }^{3}$ Floyd Bresee, "Should You Try Expository Preaching?" Ministry, September 9, 
Jesus was an expository preacher. When He preached, "they were astounded at his teaching, for he taught them as one having authority, and not as the scribes" (Mark 1:21-22). The authority that Jesus had when preaching and teaching the Scriptures, relating Scriptures to the needs of His listeners, one can have today. For that, it is necessary to have a clear understanding of the Scripture, to know the needs of the people, to preach sermons to satisfy their needs, and to have adequate preparation. With the power of the Holy Spirit this makes preaching and teaching powerful, life-changing tools.

\section{Conflict Management Skills}

No place on earth is free of conflict or its effects. Conflict started in heaven (Rev 12:7-9). Jesus's life and ministry were permeated by conflict and incomprehension (Matt 2:16; John 7:1-7). The Bible tells many stories of conflict. The early church records are full of stories of differences, strife, and fights among Christians (Acts 15:1-21). ${ }^{1}$ Of course, pastoral work is not immune from conflict of different types. Often the pastor is faced with such difficult problems among church members or with the community that he needs an extra measure of "good sense" and "ability" to handle the most different issues regarding human beings. ${ }^{2}$

'Norton, Class notes for CHMN 638.

${ }^{2}$ Means, Effective Pastors for a New Century, 216. 
Conflict is not sinful or immoral, but the way it is treated can be characterized by these two adjectives. ${ }^{\prime}$ Clifford Jones points out the benefits of conflict. It helps to clarify issues, brings solidarity to the group, and measures the power bases in the church. ${ }^{2}$

The challenge for a district pastor is not based on having or not having conflict, but on how to deal with conflict when it comes. Certain steps should be followed in order to resolve conflict in the church family. The following suggestions may be helpful for pastors who work in multi-church districts.

1. Admit the existence of conflict. Identify the issues, look for facts and evidence. Conflicts cannot be solved unless their causes are known. ${ }^{3}$

2. Deal with small conflicts immediately and directly according to biblical standards (Matt 18:15-17) before they become massive and out of control. For Jones, it is important in this step to explore a variety of alternatives to solve the conflict. ${ }^{4}$

3. Involve church members in the decision and resolution of issues. Wise pastors delegate decision-making power to those people most directly affected by the decision and provide for collaboration. This helps to avoid no-win situations and calls for unity. ${ }^{5}$

'Norton, Class notes for CHMN 638.

${ }^{2}$ Clifford Jones, Class notes for CHMN 527 Church Leadership and Administration, Andrews University, Berrien Springs, MI, July 1998.

${ }^{3}$ Norton, Class notes for CHMN 638.

${ }^{4}$ Ibid.

${ }^{5}$ Means, Effective Pastors for a New Century, 216. 
4. Affirm people instead of condemning and humiliating; then celebrate the resolution of the conflict. ${ }^{1}$

In this process of solving conflicts the pastor needs to use the channels of communication to keep church members informed. This can be done by forums, newsletters, business meetings, and so on. An open and honest communication avoids many additional conflicts or suspicion. The pastor should strive to preserve church discipline, necessary to keep unity and to help sinners to recognize their wrong path. Discipline always must be exercised in love (Heb 12:6; Rev 3:19; Prov 25:12) and administered only in the spirit of genuine Christ-like love, humility, and gentleness (Gal 6:1). Finally, the pastor needs to maintain leadership dignity with spiritual maturity and ethical behavior (1 Tim 5:17).

\section{Pastoral Roles}

A program to enhance pastoral work needs to begin by looking at pastoral roles from a Christian and biblical perspective. The SDA pastor in a multi-church context is called to perform many functions such as preaching, nurturing, visiting, counseling, evangelizing, and administering--all legitimate and necessary in themselves. The SDA Minister's Manual states that the pastor is responsible for "overseeing and fostering all branches of the work."2 Since the responsibilities and roles of the district pastor are multiple, some important roles for a more productive and enjoyable ministry must be

'Jones, Class notes for CHMN 527.

${ }^{2}$ SDA Minister's Manual, 43. 
defined. First, we consider the pastor as a spiritual leader. Second, we shall look at the pastor as equipper.

\section{Spiritual Leader}

To lead a congregation is not an easy task. It requires courage to take risk, to preach the truth, to change attitudes, and to walk in front of the flock. Spiritual leadership is different because in addition to the qualities of secular leaders, ministers bear the responsibility of conveying spiritual dimensions not expected from others. The pastor's moral influence on the congregation he leads is primary. Besides this moral influence, every member of the church is affected by the ability of the pastor to provide the kind of organizational structures, polity, and climate that are conducive to the personal and spiritual growth of its members.'

Leadership plays a critical role in any human endeavor. This is as true in the church as it is in business or government or the military. Bennis and Nanus boldly declare that "leadership is the pivotal force behind successful organizations."2 Robert Schuller follows the same idea, declaring that "there is no substitute for dynamic, aggressive, positive, inspiring leadership. Almost without exception, the lack of success means the lack of effective leadership."

${ }^{1}$ Norton, Class notes for CHMN 638.

${ }^{2}$ Warren Bennis and Burt Nanus, Leaders: Strategies for Taking Charge (New York: Harper and Row, 1985), 2-3.

${ }^{3}$ Robert Schuller, Your Church Has Real Possibilities (Glendale, CA: Regal, 1974), 49. 
Leadership in the Christian perspective is different from leadership in the secular world. While they have many points in common, the concept and purpose are different. Christian leadership has to do with the church. The church is not a secular institution nor does it operate as such. ${ }^{\prime}$ Christian leadership is different from all other kinds of leadership because it involves trying to imitate Christ, the leader par excellence. ${ }^{2}$

Walter Jackson defines spiritual leadership as "the ability to inspire and to bring people to faith in Jesus Christ; to enrich and disciple them as whole persons into whatsoever the Lord has commanded, and to lead them to achieve the goals of ministry assigned by Jesus Christ to the church." Robert Dale presents the two "M's" in spiritual leadership. He explains that mission and morale are two sides of the coin in effective leadership. Spiritual leaders both clarify mission and heighten morale. Consequently, the church members have a sharp sense of their direction and a high sense of their ability to act successfully. Note the following list of comparisons and contrasts between mission (relating to the doing aspect of spiritual leaders) and morale (the being aspect of spiritual leaders):

$\begin{array}{ll}\text { Mission (doing) } & \text { Morale (being) } \\ \text { Skill } & \text { Will } \\ \text { Goals } & \text { Goodwill } \\ \text { Targets } & \text { Teamwork } \\ \text { Stability } & \text { Loyalty }\end{array}$

${ }^{1}$ Bennis and Nanus, 3.

${ }^{2}$ Nkosiyabo Z. Zvandasara, Leading the Leader (Berrien Springs, MI: Lesley Books, 1997), 13.

${ }^{3}$ Walter C. Jackson, "Church Ministry Leadership," in Preparing for Christian Ministry: An Evangelical Approach, ed. David P. Gushee and Walter C. Jackson (Wheaton, IL: Victor Books, 1996), 170. 
Planned Change

Task-Oriented

High Structure

Tradition

Commitment

Action
Stability Zones

Relational-Oriented

Low Anxiety

Trust

Confidence

Attitude'

When pastors assume their roles as spiritual leaders and lead according to God's purpose, they inspire people to recognize their spiritual needs, values, and objectives, and then facilitate growth in these vital areas. Good, effective, spiritual leaders infuse others with enthusiasm for the person of Christ and the mission of the church. ${ }^{2}$

\section{Developing Leadership}

The district pastor has no choice; the pastor cannot neglect this fundamental pastoral role--to be a leader of God's pcople. Walter Jackson says: "If you are a minister, you do not have a choice about whether to be a leader." The only choices involve: (1) whether or not one will work consciously at the task of learning and growing as a leader, and (2) whether or not one will choose with care the style or styles of leadership used in leadership activities. ${ }^{3}$ Fortunately God can use different styles and personalities of leadership, and pastoral leadership skills can be learned. ${ }^{4}$

\footnotetext{
68- 69.

'Robert Dale, Leadership for a Changing Church (Nashville: Abingdon, 1998),
}

${ }^{2}$ Means, Leadership, 65.

${ }^{3}$ Walter C. Jackson, "The Minister as Leader," in Formation for Christian Ministry, ed. Anne Davis and Wade Rowatt, Jr. (Louisville, KY: Review and Expositor, $1981), 159$.

${ }^{4}$ See leadership style in Jonas Edson Arrais Matos, "A Lay-leadership Training Program for the Seventh-day Adventist Church in Brazil" (D. Min. dissertation, Andrews University, Berrien Springs, MI, 1997), 65-90. 
Whether a leader is born or made is not the issue in this dissertation. I start with the view that every district pastor must become a spiritual leader. Jeffrey Arnold's concept is one I agree with: "Leadership ability is not necessarily something you are born with. It does come more naturally to some people than to others, but most pastors can develop their ability to lead with time, endeavor, desire, and experience."' Describing the pastor's roles, Ellen White declared that "solemn are the responsibilities resting upon those who are called to act as leaders in the church of God today." We would not be misinterpreting these words if we said that one of the responsibilitics of the pastor and also his privilege is to execl in his efforts to become a better leader.

Another important point in spiritual leadership is that no onc can give a pastor leadership of a church by a one-time appointment or election. Leadership is always earned and never bestowed. No call, contract, credential, or ecstatic religious experience can make an individual a leader. Even in those who have the leadership gift, pastoral leadership develops and matures in the grucling climate of education and experience. As in other offices, pastoral leadership demands a price to pay to be a leader par excellence. No personal endowment ensures excellence without the discipline of learning and incessant diligence. This is especially true concerning the pastor as a spiritual leader. ${ }^{3}$

Pastoral leadership is accomplished by cognitive and experiential development. The cognitive development involves an ongoing process of extensive reading on

'Jeffrey Arnold and Stephanie Black, The Big Book on Small Groups (Downers Grove, IL: InterVarsity, 1992), 58.

${ }^{2}$ White, The Acts of the Apostles, 92.

${ }^{3}$ Means, Effective Pastors for a New Century, 154. 
leadership and interpersonal relations, attending leadership seminars, and preparing material to equip and train others to become leaders. It involves working as a member of a team in the church and the humility to learn from others. It requires willingness to invest time in church leaders and to share experience with learners.'

J. Oswald Sanders's book Spiritual Leadership brings out beautiful insights on Christian leadership. One has to do with his analysis of the pastor's need to aspire to leadership. It is truly right for a pastor to want to be a leader. As Sanders points out, "No doubt, Christians must resist a certain kind of ambition and rid it from their lives. But we [pastors] must also acknowledge other ambitions as noble, worthy, and honorable."

In other words, to aspire to become a good leader should be as normal in the life of a pastor as aspiring to be a better Christian every day. There is nothing wrong with this kind of ambition. The problem lies in the heart's motivation, what propels one to want to be a great leader. The problem comes when this ambition is motivated by personal and selfish interests. Sanders supports the idea that desiring to be a great spiritual leader is not sin. "It is motivation that determines ambition's character. Our Lord never taught against the urge to high achievement, but he did expose and condemn unworthy motivation. Ambition that centers on the glory of God and welfare of the church is a mighty force for good."

${ }^{1}$ Ibid. $13-14$.

${ }^{2} J$. Oswald Sanders, Spiritual Leadership, updated ed. (Chicago: Moody, 1994), ${ }^{3}$ Ibid., 15. 
District pastors in Brazil must be willing to exercise leadership. In turn, however, the congregation that wants to grow must give the pastor freedom to exercise leadership. The principles that should guide spiritual leadership are the following:

1. Exhibit a lifestyle that others will want to follow. As Paul says to young Timothy, "Be an example to the believers"(1 Tim 4:12).

2. Develop open relationships with the members of the church and minister to them so they can see how you react in everyday situations.

3. Create an environment where members can develop their spiritual gifts in a varicty of ministries and strengthen their relationship with Christ.

4. Produce leaders by an ongoing process of tcaching and equipping until they become mature leaders and, in turn, produce other leaders. The application of this principle will turn the task of spiritual leadership into a great and wonderful experience.

\section{Leadership as Lifestyle}

Webster's definition "to lead" can be applied to pastoral leadership: "to show the way to, or direct the course of, by going before or along with." By this definition, one thing becomes apparent. The leader cannot show someone clse the way to go unless he/she has been there (or is going there). In other words, the quality of pastoral life and ministry will determine the quantity of one's influence. Spiritual leadership, in other words, is a lifestyle. The pastors will influence others only in proportion to the type of lifestyle they lead. ${ }^{2}$

'Webster's New World Dictionary, College edition (1988), s.v. "Lead."

${ }^{2}$ St. Clair, 51. 
James Means states that the most compelling requisite for pastoral ministry is "leadership authenticity and competence." Leaders consumed with vision and passion, who say with integrity: "Follow my example, as I follow the example of Christ" ( 1 Cor 11:1). For John Harris, the inauthenticity of the clergy "is the greatest weakness of organized religion." ${ }^{2}$ James Cress, furthermore, adds another aspect that can be a barrier to developing efficient pastoral leadership. He says that "when leaders [pastors] act differently than their expressed values, people lose confidence. If my life does not match my proclamation, people ultimately disbelieve my words."

Jesus reserved His severest rebuke for the Pharisees who were incompetent spiritual leaders. He called them "blind guides" who "shut the kingdom of heaven in men's faces" (Matt 23:13). While spiritual leaders cannot be perfect, pastors must strive to be an example "in speech, in life, in love, in faith and in purity" (1 Tim 4:12). Spiritual leadership depends on character (1 Tim 3:2) and the requisite skills (2 Tim $3: 17$ ). So, the pastor as spiritual leader must be authentic and be an able representative of and role model for the church. ${ }^{4}$

'Means, Effective Pastors for a New Century, 51.

${ }^{2}$ John C. Harris, Stress, Power, and Ministry (Washington, DC: Alban Institute, 1977), 3.

3James A. Cress, "How to Destroy Your Leadership," Ministry, January 1996, 30. ${ }^{4}$ Means, Effective Pastors for a New Century, 19. 


\section{Qualities for a Christian Leader}

Much can be said about the qualities that are indispensable in the life and ministry of the pastor. Calvin Rock, in his book Church Leadership: A Call to Virtue, deals with several virtues that reflect qualities of character for Christian leaders. He presents courage, trust, honesty, decisiveness, loyalty, and self-control among the most important qualities that must be present in Christian Ieadership. He says that "the church suffers or succeeds in proportion to the virtue of its leaders." Malphurs summarizes the fundamental qualities for effective Christian leadership: "Christian leaders are godly persons [character] who know where they are going [vision] and have followers [influence]." ${ }^{2}$ Two other important qualitics could be added: servant-leadership and authority.

Godly character

Godly character is the foundation of any leadership. ${ }^{3}$ Nothing is more important than this quality. It is the core element that qualifies any Christian to lead others. ${ }^{4}$ Taylor points out that "a man or woman of character is a person not only of sterling 1990), 8.

'Calvin B. Rock, Church Leadership: A Call to Virtue (Boise, ID: Pacific Press,

${ }^{2}$ Aubrey Malphurs, Planting Growing Churches for the $21^{\text {st }}$ Century (Grand Rapids: Baker, 1992), 126.

${ }^{3}$ Warren Wiersbe and David Wiersbe, 10 Power Principles for Christian Service (Grand Rapids: Baker, 1997), 20.

${ }^{4}$ Maxwell, Developing the Leaders Around You, 47-48. 
integrity but of courage, discipline, perseverance, and rock-ribbed stability." A godly character earns people's respect and produces trust--the most essential ingredient in all pastoral leadership. Ted Engstrom presents the leadership characteristics of Moses as described in Heb 12: Moses had faith (v. 24) and integrity (v. 25); he was a man of vision (v. 26); he was decisive (v. 27); he was obedient (v. 28); and he was responsible (v. 29). ${ }^{2}$

Character is what Jesus described in the beatitudes (Matt 5:3-12) and demonstrated in His own life and ministry in the Gospels. Character is made up of those beautiful qualitics that Paul called the "fruit of the Spirit" in Gal 5:22-23. In this list, Paul sets the critcria for developing and measuring a Christian character. The sowing of such virtues is essential to develop effective Christian leaders.

For Warren Wiersbe, a healthy and holy character is formed by making Scripture a part of one's inner being and obcying what it says. It comes from faithfully spending time in prayer and diligent study of the Bible, gladly making sacrifices and willingly serving others. ${ }^{3}$ In character formation, one needs to consider the role of the Holy Spirit. He is the divine agent who transforms lives and develops Christian character. Ellen White writes that "the Christian life is not a modification or improvement of the old, but

\footnotetext{
${ }^{1}$ Richard S. Taylor, Principles of Pastoral Success (Grand Rapids: Francis Asbrury, 1989), 51. 1976), 30.

${ }^{2}$ Ted W. Engstrom, The Making of a Christian Leader (Grand Rapids: Zondervan, ${ }^{3}$ Wiersbe and Wiersbe, 20.
} 
a transformation of the nature. There is a death to self and sin, and a new life altogether. This change can be brought about only by the effectual working of the Holy Spirit."

Vision

Effective pastors are visionary leaders. According to Burt Nanus, "there is no more powerful engine driving an organization [church] toward excellence and long-range success than an attractive, worthwhile, and achievable vision of the future, widely shared." With vision, the leader provides the all-important bridge from the present to the future of the organization. ${ }^{3}$ A vision is an attempt to articulate. as clearly and vividly as possible, the desired future state of the church or organization. The vision is the goal that provides direction, aligns key players, and encrgizes people to achieve a common purpose. ${ }^{+}$According to Warren's concept, "Vision is the ability to see the opportunities within your current circumstances." James Cress goes further, stating that vision helps the pastor and church members to look beyond the actual circumstances. "Those who

${ }^{1}$ White, Desire of Ages, 172.

${ }^{2}$ Burt Nanus, Visionary Leadership: Creating a Compelling Sense of Direction for Your Organization (San Francisco: Jossey-Bass, 1982), 3.

${ }^{3}$ Bennis and Nanus, 90.

${ }^{4}$ Ralph H. Kilmann and Teresa Joyce Covin, Corporate Transformation: Revitalizing Organizations for a Competitive World (San Francisco: Jossey-Bass, 1988), 135.

${ }^{5}$ Rick Warren, The Purpose-Driven Church (Grand Rapids: Zondervan, 1995), 28. 
cannot see beyond the immediacy of today will seldom prepare for tomorrow." Thom Rainer points out that the pastor needs to "teach his church to be visionary."

Some essential elements that may help develop an effective vision in the local congregation are the following:

1. An effective vision is inspiring and challenges people to accept ideas and transform them into action. Vision involves action. Visionary leadership demands intentional action in carefully selected areas of the church. Vision is not a fantasy or mere plans and goals; it is an attitude that is motivated to act and choose directions most likely to promote healthy and constant transformation. Effective vision happens when high purpose and intense pragmatism meet. ${ }^{3}$ It is true that a worthy vision may emerge from a dreamer's imagination, but it must be plausible and possible to put in action.

2. Effective vision is clear, specific, and communicable. Dale Galloway, in his book 20/20 Vision, describes how pastors can transfer or communicate their vision to the congregation: First it is necessary to get a clear picture of the vision. Second, a strong commitment must be made to make the vision become a reality. Third, prayer is offered for God to confirm the vision. Fourth, one must organize resources and concentrate on

\section{${ }^{\mathrm{I}}$ Cress, 30.}

${ }^{2}$ Thom S. Rainer, The Book of Church Growth: History, Theology and Principles (Nashville: Broadman and Holman, 1993), 189.

${ }^{3}$ Tom Peters and Nancy Austin, A Passion for Excellence (New York: Random, 1985), 490. 
making the vision happen. Fifth, one must be willing to risk failure as he or she reaches out to fulfill the vision. Sixth, faith must be applied to it.'

3. An effective vision is both stable and flexible. It pursues stable goals but is continually adjusting through time. It must be open to change.?

4. An effective vision cmpowers and cnables people to work together to accomplish tasks and reach goals. Pastors need to inspire their congregation with what is possible, have them participate in developing the vision, thereby helping them to own the vision, and then as a team work out the strategy to see that the vision becomes a reality. This process involves trust in people, to affirm them and to delegate to them their work to accomplish the task, focusing on prioritics. ${ }^{3}$

5. Vision must be the fruit of faith and according to God's will. The pastor is key to provide vision; it seldom arises from the members. An effective vision is more than something the leader has manufactured; it must be Bible-based and God-honoring. It must contribute to the expansion of God's cause and accomplish His purposes. It is not the development of a personality cult or an egocentric human enterprise. ${ }^{4}$

The SDA church in Brazil needs visionary pastors, those whose dreams and

'Dale E. Galloway, 20/20 Vision: How to Create a Successful Church (Portland, OR: Scott, 1986), 33-41.

${ }^{2}$ Adapted from Barry N. Crane, "Teamwork: The Lay Leaders's Guide to Church Growth" (D.Min. dissertation, Fuller Theological Seminary, 1992), 78-85.

${ }^{3}$ Ibid.

${ }^{4}$ Ibid., 85 . 
understanding of the mission of the church are open to new possibilities and paradigms, and who articulate a new, realistic, credible, attractive future for the church, a condition that is better in some important ways than what now cxists.

Influence

Most definitions of leadership--both secular and Christian--include the concept of influence. The essence of leadership is influence.' No matter how many definitions one applies to leadership, influence is the term that summarizes the nucleus of its meaning. The primary function of leadership is to direct and inspire behavior to obtain particular goals. ${ }^{2}$ J. Robert Clinton defines a Christian leader as one who brings the Christian influence into his particular group or situation. He says that a leader is "a person with God-given capacity and with a God-given responsibility to influence a specific group of God's people toward God's purposes for the group." ${ }^{\prime 3}$ Malphurs says that Christian leaders exert a powerful influence on people. "They are like magnets in that they attract people. When they turn around and look behind them, they see people. Those who insist that they are leaders but have no one following them, are not leaders at all." ${ }^{\prime 4}$

'John C. Maxwell, Developing the Leader within You (Nashville: Thomas Nelson Publishers, 1995), 49, 105. 1992), 21.

${ }^{2}$ Edgar J. Elliston, Home Grown Leaders (Pasadena, CA: William Carey Library, ${ }^{3}$ J. Robert Clinton, The Making of a Leader (Colorado Springs, CO: NavPress,
1988), 245.

${ }^{4}$ Malphurs, Planting Growing Churches, 129. 
The influence of Christian leaders has been a great power to touch and transform many lives. Christian leaders have the responsibility to influence people toward God's purpose. Christian leadership in Christ's church is to be concerned with the inner growth and development of the believer.

The influence of the pastor as a leader is not only a reality in the personal lives of the church members and outside community but in the whole process of church growth. In church growth literature, every source emphasizes the vital role played by pastoral leadership in facilitating and influencing growth. Peter Wagner, in Leading Your Church to Growth, declares that the first vital sign of a healthy growing church is "a pastor who is a possibility thinker and whose dynamic Icadership has been used to catalyze the entire church into action for growth."' Lyle Schaller agrees with Wagner's concept that pastoral leadership is the "most critical single factor" for productive ministry resulting in church growth. ${ }^{2}$

Authority

The issue of authority remains central to the work of pastoral leadership. According to Fisher, "We live in a culture in which submission to authority, especially moral or spiritual authority, is anathema." ${ }^{\text {Th }}$ Thus, pastoral authority needs to be understood in order to be exercised within a Christian perspective. Because authority has 78.

'C. Peter Wagner, Leading Your Church to Growth (Ventura, CA: Regal, 1986),

${ }^{2}$ Lyle Schaller, The Senior Minister (Nashville: Abingdon, 1989), 10.

${ }^{3}$ Fisher, 230 . 
to do with power, one cannot ignore issues of authority such as who has authority, how it is given or taken, and how it is exercised.

Erich Baumgartner brings some helpful insights to this issue. For him, power is simply the potential to influence others. Authority is the legitimate use of power.' Another interesting point regarding spiritual gifts and spiritual authority is that the primary source of authority is rooted in a leader's (pastor's) experience with God, which is recognized throughout the church. The gifts that the pastor has cstablish his/her potential for ministry. The authority of the pastor, therefore, is not based on the gifts but on the calling of God to help the church. Thus, while spiritual gifts equip the pastor for a leadership function, the calling of the church to an office indicates the sphere of influence or authority the church is willing to recognize in a person.?

The minister's authority is related to his capacity to develop spiritual leadership, motivated by faithful service for the church. This is authority exercised on behalf of others. Jesus exercised His authority on behalf of those He came to serve and save. He sought to use His power to assist rather than control those He encountered. In pastoral leadership, authority is not granted by ecclesiastical hierarchy, rule, ability, or job description; it flows from below, from the people. It can be earned only by love. It is earned by loving the church as Christ loved it (Eph $5: 25 ; 6: 4){ }^{3}$

'Erich W. Baumgartner, "Towards a Model of Pastoral Leadership for Church Growth in German-speaking Europe" (Ph.D. dissertation, Fuller Theological Seminary, 1990), 67.

${ }^{2}$ Ibid., 69-70.

${ }^{3}$ Norton, Class notes for CHMN 638. 
Authority is the ability to influence others, to be respected and supported without major objection, to be accepted. Howard Rice points out that "authority is the power or right to influence the actions of others. Authority is closely related to authorization; to exercise authority is to receive the right to power from a higher source; authority is neutral power that one can exercise for good or evil." For Eddie Gibbs, the minister's authority is a result or fruit of a sincere and loving relationship with God and His people. This authority is "built up through living relationships with people." As a result of this, respectful relationships begin to develop between the pastor and the congregation. This is based not only upon respect but on love and commitment. The way the pastor treats and serves the people is a decisive factor in gaining pastoral authority.

Pastoral authority is related to the exercise of spiritual leadership. Two factors are fundamental in this issue: the lifestyle of the leader-pastor and the style of leadership marked by passionate love and dedicated service toward church members and its community. Wagner uses the biblical relationships in a well-balanced family to explain how this pastoral authority is granted. He maintains that just as in a well-balanced family a father who loves his wife and brings his children up in the fear and the admonition of the Lord receives the respect and submission of his family, so does a pastor who earns this respect. ${ }^{3}$ In short, genuine authority comes from God and is gained by sincere relationships and dedicated work on behalf of church members.

'Rice, 171.

${ }^{2}$ Eddie Gibbs, I Believe in Church Growth (Grand Rapids: Eerdmans, 1981), 256.

${ }^{3}$ Wagner, Your Church Can Grow, 61-62. 
this respect.' In short. genuine authority comes from God and is gained by sincere relationships and dedicated work on behalf of church members.

\section{Servanthood}

There are different styles of leading, but servant leadership should be the model for Christian leadership. Some have a tendency to confuse leadership with the desire to occupy a position in the church, to be in the limelight. The pastor must understand that the real meaning and the highest quality in Christian leadership is to be a servant.

A theology of pastoral ministry based on the concept of being a servant is at the heart of the NT. ${ }^{2}$ "I am among you as one who serves," Jesus told His disciples (Luke 22:27). While the disciples were arguing among themselves as to who would occupy the highest positions of authority, Jesus used those haunting words to explain a Kingdom principle: "Whoever wishes to be great among you must be your servant, and whoever wishes to be first among you must be your slave; just as the Son of man came not to be served but to serve, and to give His life a ransom for many" (Matt 20:26-28).

Many such Scripture texts may be cited in support of the concept that ministry is primarily a service to others on behalf of God. Ray Anderson notes that an effective servant leader must possess three things: "a creative vision that inspires, a delegated power that enables, and a spiritual gift for ministry."3

'Wagner, Your Church Can Grow, 61-62.

${ }^{2}$ Ray S. Anderson, The Soul of Ministry (Louisville, KY: Westminster John Knox, 1977), 79.

${ }^{3}$ Ibid., 197. 
Pastors as servant leaders lead only when they see their assignment as an opportunity for service. Leading and serving are permanently tied together in the Christian way. At all levels of church life, genuine leaders are servants. Neil Wiseman says that "the path to true greatness is always the royal road of service."'

Pastors must not confuse the biblical principle of servant leadership with being a slave. Servant leadership is not to be confused with passivity and indecisiveness. In Jesus, servanthood is revealed as a base of strength and authority. While He made the towel a supreme symbol of servant love (John 13), He refused to be a mere victim of circumstance and human wishes. As God's servant, the pastor is called to model spiritual authenticity and, in a spirit of abnegation and service, lead church members to follow this model. $^{2}$

\section{Tasks of Leadership}

The district pastor is called upon to perform many tasks. Although leadership potential depends basically on personality, spiritual giftedness, and willingness to pay the price to be a leader, there are many things a pastor needs to do. Among them, management/administration and shepherding are indispensable.

Management and administration

The concepts of management and leadership are related, but with an important distinction. Leadership refers to the process of influencing individuals and groups

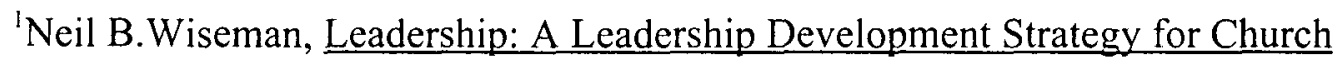
Growth (Kansas City, MO: Beacon Hill, 1979), 20-21.

${ }^{2}$ Baumgartner, 71-72. 
toward achieving certain common goals. Managers usually exercise some leadership, consequently, the words management and leadership are often used interchangeably. The district pastor needs to recognize that to be leader is important, but management and administration play key roles in pastoral work.' The church must be led, but the church must also be managed. The church is both an organism, the body of Christ, and an organization that requires administration. ${ }^{2}$ Drucker lays it out clearly; saying that as a church "we need management and organization."."

In many districts comprised of small churches and companies, the pastor must assume the function of management more than leadership. Management skills are necessary to be effective in pastoral work in this context. Schaller makes distinctions between pastors who are shepherds (the small church), those who are ranchers (the middle-sized church), and those who must be presidents (the large church). ${ }^{4}$

When pastors do not have well-defined roles for their work and do not take account of their role as leader and cquipper, the laity have a tendency to pressure their pastors to adopt a managerial style of ministry. My own experience in the first years of ministry attests that it is true and must be avoided for the sake of a more productive and satisfactory ministry. In my first years of pastoral work in large districts there were so

\footnotetext{
'Although I recognize that most books dealing with this subject make a difference between management and administration, in this dissertation I use these two words interchangeably.

${ }^{2}$ Lyle E. Schaller, Getting Things Done (Nashville: Abingdon, 1986), 3.

${ }^{3}$ Drucker, 79 .

${ }^{4}$ Lyle E. Schaller, The Multiple Staff and the Larger Church (Nashville: Abingdon, 1980), 21.
} 
many things to do in terms of management and administration in such a wide range of activities, such as purchases, construction, administrative and board meetings, that other important spiritual disciplines and preaching-teaching remained neglected. Other pastors have a similar experience.

Bruce Jones indicates that "in one church-growth research project it was discovered that in many churches, 85 percent of available time is given to management, while only 15 percent of time is given for ministry." Although managerial and administration skills are necessary for the district pastors, balance and prioritization are indispensable. At the same time the pastor cannot neglect the managerial aspects of pastoring; these need to be watched carefully so as not to absorb his time excessively.

Some pastors who are task-oriented see administration as one more task to be accomplished. As they set about doing the big tasks, the management of people and programs can get in the way. They have a tendency to take on too much and become frustrated with that which interferes with accomplishing the goal. On the other hand, some pastors are more people-oricnted. Administration for them is an interruption to their commitment to minister directly to people. ${ }^{2}$

Pastoral work demands a balance between what is necessary in terms of managerial work without neglecting other aspects of ministry. If a pastor does not have the gift of administration, he needs to work closely with those lay members who do have

'Bruce W. Jones, Ministerial Leadership in a Managerial World (Wheaton, IL: Tyndale, 1988), 88. $8-9$.

${ }^{2}$ William B. Hull, “The Pastor: Ministry or Administrator?” Ministry, May 1978, 
it. On the other side of the spectrum, those who do like and enjoy managerial work must be careful not to overload themselves with it and to be wise enough to delegate tasks.

Proctor and Taylor warn that pastors must be careful not to excel in the administrative aspects of the job to the detriment of pastoral duties. They ask: "How much hands-on administration does a pastor really need to do?" Their answer is very precise: "Many things in the church would resolve themselves if we are not around all the time. A pastor needs to be close enough to know what is going on, but that pastor does not need to know evcrything." Quite often ministers are tempted to manage or administrate many "things" that other members of the church, if trained and cmpowered. could do for themselves. In this important role of pastoral leadership, pastors need to learn to say "no" to many activitics that are supposedly required of them.

Peter Drucker makes an important point to guide pastors in terms of managerial work in the church: "All demands must be measured against your one unique function-ministry to persons. Say no to the demands that don't fit that role. And say no often, because ministers today are asked to play many other roles."2 He further says that in doing managerial and administrative work, the pastor cannot forget that the central purpose of the congregation and pastoral work is the person. The objective of the minister is to build up people. ${ }^{3}$

\footnotetext{
${ }^{1}$ Proctor and Taylor, 54.

${ }^{2}$ Drucker, 79.

${ }^{3}$ Ibid.
} 
Don Cousins and Leith Anderson reinforce this point. Ministers need to keep in mind that management is ministering to people and must be people centered.' Focus on this purpose of the pastoral leadership role in managerial and administrative work can lead to integral growth of the church in Brazil.

Shepherding.

Pastoral leadership needs to take into consideration this important role for effective pastoral ministry. The Bible endorses this pastoral role. This dimension of pastoral leadership is presented in the Bible, especially in Ezck 34:2-4 and John 10:1-16. The word "shepherd" (poimein) literally means "one who cares for sheep" (Matt 9:36); it is used metaphorically of Christ (Matt 26:31; Mark 14:27) and of pastors in the churches (Eph 4:11). ${ }^{2}$ Most litcrature has a strong emphasis on the pastor as a shepherd, on pastoral care, visitation, nurturing, counseling, and so on. Of course, this work of a shepherd not only applies to paid ministry, but the district pastor does have responsibility to provide shepherding.

Scripture establishes that shepherding is a spiritual gift (Eph 4:8,11), a vocation initiated by a gift granted by the Holy Spirit. The Bible upholds shepherding as a noble vocation with a function rooted in love. A spiritual shepherd is a channel through whom the Holy Spirit works to meet the numerous needs of human souls. Thus, the image of a

'Don Cousins, Leith Anderson, and Arthur DeKruyter, Mastering Church Management (Portland, OR: Multnomah, 1.990), 42.

${ }^{2}$ W. E. Vine, An Expository Dictionary of New Testament Words, 5 vols. (Westwood, NJ: Fleming H. Revell, 1952), 2:210. 
shepherd pictures God's compassionate ministry toward mankind.' Thomas Oden calls shepherding "the unifying image of ministry."?

The role of shepherding seems to be misunderstood by church administrators and even by pastors themselves. Very often pastoral ministry is understood as a professional executive position. But to do effective pastoral work, this trait of pastoral leadership cannot be neglected.

From the OT prophet Ezekiel comes an outstanding message which outlines clcarly a thcology of ministry for shepherds. Ezekiel's sermon is presented negatively, showing the failures of the shepherds of Israel. When the message is presented in a positive way, it delineates the kinds of ministries a pastor is supposed to be engaged in: (1) shepherds are to feed the flock, not themselves; (2) they are to strengthen the weak and diseased, to heal the sick, bringing God's grace to bear upon spiritual, cmotional, and physical hurts; and (3) shepherds are to bind up the broken, to bring back those who have wandered, or who have been driven away to scek the lost, and to lead the flock, not rulc them with force and cruelty. When force and cruelty are used, the sheep scatter and become prey to "all the beasts of the field.".

'Francy Duran, "Spiritual Nurture in the Local Seventh-day Adventist Congregation through the Spiritual Gifts of Prophecy and Shepherding" (Ph.D. dissertation, Andrews University, Berrien Springs, MI, 1996), 113.

${ }^{2}$ Thomas C. Oden, Pastoral Theology: Essentials of Ministry (San Francisco: Harper and Row, 1983), 50.

${ }^{3}$ Adapted from F. J. May, "The Book of Acts and Church Growth" (D. Min. dissertation, Fuller Theological Seminary, 1988), 94. 
Another picture of the "Good Shepherd" is described in John 10:1-16. Here, Jesus, the Chief Shepherd, gave us a clear understanding of His own concept of ministry:

1. The good shepherd is open and above board in all his goings and comings. He enters the fold by the door and does not try to climb up any other way.

2. He calls his sheep by name, knowing them intimately, and leads them forth.

3. The shepherd trains his sheep and relates to them in such as way that they know his voice and follow his leadership.

4. The good shepherd is willing to lay down his life for the sheep.'

William Hull summarizes in three words Jesus' concept of the shepherd in John 10: the good shepherd "gathered his sheep into one flock (vv. 3-4, 14-16, 27), insuring the unity of the church." Next, he "gularded his sheep from destruction (vv. 7-8, 11-15, 20-29), insuring the security of the church." Then, "he guided his sheep into good pasture (vv. 3, 9-10,28), thus insuring the vitality of the church.,"2

At the end of the twentieth century, the dramatic changes in the way people go about their lives and the changing nature of the pastoral role have radically altered pastoral visitation and spiritual-care ministry. This is a reality in most of the districts in Brazil, especially for pastors who work in large districts and big cities.

Church members in Brazil still have high expectations in terms of pastoral care and visitation. For many church members, the role of the pastor is only to shepherd them, to visit them, and so on. Generally speaking, this creates a serious problem for

'Ibid., 95.

${ }^{2}$ William E. Hull, "Commentary on John 10," The Broadman Bible Commentary, 12 vols., ed. Clifton J. Allen (Nashville: Broadman, 1970), 9:303-304. 
pastoral work in a multi-church district. The church members portray their pastor as a shepherd and want their pastor to perform this role. But many times the pastor faces two barriers. First, when the pastor has a large district with over one thousand people scattered over a large area, it becomes very difficult to shepherd the "flocks" and supply all their needs. Second, many pastors feel they are not gifted to successfully fulfill the shepherding facet of ministry required of them. Chapter 4 presents some suggestions to deal with this reality.

Win Arn points out that "not everyone who has the office of pastor needs the gift of pastor." Of course, this does not exempt the district pastor from doing the work of a shepherd, such as member visitation and other forms of pastoral-care ministry. But certainly, in the light of the principle of spiritual gifts, it is evident that not every pastor has this gift. The least the pastor can do within his responsibility is to provide this pastoral care through lay elders, deacons, deaconesses, and other gifted and trained members.

What really matters is not who is ministering pastoral care, but that in all healthy churches, regardless of size, pastoral care and one-to-one ministry takes place. The healthy and continuing growth of the church greatly depends on how well spiritual care is provided. Although technological resources must be used to facilitate pastoral work, shepherding cannot be done through sterile answering services, computerized messages,

\footnotetext{
'Win Arn, The Pastor's Church Growth Handbook (Pasadena, CA: Church Growth Press, 1979), 44.
} 
and impersonal form letters. In other words, shepherding cannot be done by an absentee person. Being a shepherd is an extremely personal matter. ${ }^{\prime}$

\section{Equipper}

This pastoral role is not cmphasized in Brazil. Most pastors do not pay much attention to this important role of ministry. The "equipping" concept is based on one passage: Eph 4:11-12. The Apostle Paul expresses it this way: "The gifts he gave were that some would be apostles, some prophets, some evangelists, some pastors and teachers, to cquip the saints for the work of ministry, for building up the body of Christ." Thus, for Paul, the need for total involvement of all members in ministry was the equipping ministry. According to this statement in Ephesians, Paul declared that a major function of all ministers, regardless of title or position, is to equip members to become mature Christians who use their spiritual gifts to minister Jesus' love both in the church and in the world. In the equipping-ministry model, other functions of the pastor such as preacher, prophet, pastor, priest, evangelist, counselor, administrator. and teacher find their proper places.

In the book of Acts and the Epistles, one can see Paul himself as an equipper of others. As soon as he planted a new church, he immediately recognized what God wanted to do through others and dedicated time and energy to help them achieve their own function or ministry in the body of Christ. Paul not only enjoyed bringing people into fellowship with Christ but he also helped them develop their potential gifts in ministry.

'Oden, 171-172. 
Paul is a good example of a minister or pastor who incarnates this role in his pastoral ministry. He was constantly developing the equipping ministry in others. It is remarkable to observe this in his relationship with Timothy. He wrote: "And what you have heard from me through many witnesses entrust to faithful people who will be able to teach others as well" (2 Tim 2:2). For Paul the priority in his ministry was teaching and equipping. He rejoiced to see his own ministry multiplying and expanding.

When Paul did ministry based on equipping people to service or ministry, he was only following Jesus' cxample. Christ dedicated most of His ministry to training and equipping His disciples to be involved with Him and to carry on after His own mission was completed.'

Pastoral work in multi-church districts urges pastors to recognize and assume their role as equippers. This above all other biblical roles needs to be taken seriously. When pastors follow this model they can roll from their shoulders a great burden and have a more joyful and productive ministry. It is more than the recognition of a role, it must be direct and even permeate the whole idea and focus of pastoral ministry in multichurch districts.

In Can the Pastor Do It Alone? Melvin Steinbron reports his own experience doing a stressful and fruitless ministry. He explains that for thirty years, he knew the biblical teaching of Eph 4:11-12 regarding lay people equipped for ministry, but did very little with it. Then, he says, God called him to accept and to practice the biblical teaching regarding the equipping of the saints for ministry. It led him into the best years of his

'May, 99. 
ministry. He describes how his ministry changed for the better: "In this new form of ministry, I have been able to 'serve the Lord with gladness' (Ps 100:2) in new ways, because I no longer have to bear the burden of ministry alone, nor wrestle with the problems myself. Now there many people committed and they are working in a significant ministry." Based on his own experience, he points out that "the pastor must become convinced that cquipping lay people is God's call and priority for his ministry."

Among SDA teachers of ministry, Russell Burrill has made a great contribution bringing this biblical teaching to the SDA pastors. He strongly emphasizes that the work of the pastor is to prepare God's people to do the work of ministry. If he is not doing that, biblically he is not doing his job." "When the pastor takes over the ministry function of the church and neglects the training function, the church becomes weak spiritually." He further declares that "training is an absolutely vital component that will require significant pastoral attention if people are to function effectively in ministry."

Ellen White's writings portray an even greater emphasis on this role or function of the pastor. She says that "sometimes ministers do too much; they seek to embrace the whole work in their arms, ... while the members of the church stand idle. This is not $21-22$.

'Melvin J. Steinbron, Can the Pastor Do It Alone? (Ventura, CA: Regal, 1987),

${ }^{2}$ Ibid., 23.

${ }^{3}$ Burrill, 48.

${ }^{4}$ Ibid., 49.

${ }^{5}$ Ibid., 107. 
God's order at all." Elsewhere she notes: "The greatest help that can be given to our people is to teach them to work for God, and to depend on Him, not on the ministers." "Let the minister devote more of his time to educating than to preaching.". She further declares that "the minister should at first seek not so much to convert unbelievers as to train the church members for acceptable co-operation. ${ }^{.4}$ The following quotation had a great influence on my own ministry: "Many would be willing to work if they were taught how to begin. They need to be instructed and encouraged. Every church should be a training school for Christian workers." Undeniably, pastors have total support from the Bible and Ellen White to develop a pastoral ministry around the concept of equipping the saints to ministry.

There are many benefits and advantages in assuming this pastoral model or role. Some of them are as follows.

Equipping members forces the pastor to recognize the biblical teaching of the priesthood of all believers. This has been emphasized in chapter 2. The pastor who accepts that he is not alone in the ministry of the church and that every believer is a minister and as such has a ministry to perform could have a more effective and productive ministry.

${ }^{1}$ White, Evangelism, 113.

${ }^{2}$ White, Testimonies for the Church, 7:19.

${ }^{3}$ Ibid., 20.

${ }^{4}$ White, Gospel Workers, 196.

${ }^{5}$ White, Christian Service, 59. 
The teaching role leads the pastor and church members to recognize the doctrine of spiritual gifts and the role of the Holy Spirit in bestowing gifts for God's people to build up the body of Christ, the church. The Holy Spirit is the divine agency who apportions to each member as He wills the gifts that provide all abilities and ministries needed by the church to lulfill its divinely ordained functions. The gifts are given for service. Through the inner working of the Holy Spirit in their lives, church members are empowered and equipped for ministry in the church. This concept can bring new ways to do pastoral work in Brazil. It frees the pastor so that he can perform the ministerial duties with more satisfaction and with the total conviction that this it is biblically sanctioned.

According to Barna, the pastor's role as an equipper involves the responsibility to help church members in the process of discovery, development, and implementation of their spiritual gifts. He suggests the need (1) to identify those gifts and talents, (2) to refine those gifts by training, (3) to provide opportunities for the individual to utilize those gifts in a significant ministry, and (4) to support the individual in that ministry is an ongoing process.'

Wagner also favors the equipper model for pastors. He states that "an equipper is a leader who actively sets goals for a congregation according to the will of God, obtains goals ownership from the people, and sees that each church member is properly motivated and equipped to do his/her part in accomplishing the goals."2 When pastors

\footnotetext{
'Barna, User Friendly Churches, 1.

${ }^{2}$ Wagner, Leading Your Church to Growth, 79.
} 
recognize the great potential and resources that God provides for His church in the form of natural abilities and spiritual gifts, and assume their role as equippers, their pastoral work can be more joyful and efficient.

Another benefit of equipping members would be proper time management and delegation. In this model the pastors recognize that they do not need to work alone, they can delegate. Delegation is an important aspect in the equipping process and proper time management. It means that pastors recognize that they cannot minister alone but do so in a dynamic partnership with God and the people of their church. The laity become ministers, and pastors become equippers of the ministers. The result is a decentralized pastoral ministry in which pastors do not do cverything for themselves, but empower people, trust them, and delegate responsibilities. In this model, the pastorate shifts or moves from "I do" to "we do together."

Regarding the importance of delegation Norton points out that lay participation can be a powerful activity to promote growth in a church, improve performance, and grant more respect and authority to ministers. It can also bring a variety of new gifts to the church that without delegation would remain dormant. Delegation not only distributes the load of the minister (Exod 18:22), but at the same time gives him more time for other important dutics.'

Carl George emphasizes that successful pastors realize the necessity for lay persons to act as team leaders. They must arrange their ministry around the concept that God does not want the clergy to do everything themselves; He counts on the laity to do

\footnotetext{
${ }^{1}$ Norton, Class notes for CHMN 638.
} 
it.' One of the causes of stress and overload of the pastor is that "they haven't mastered the art of raising up fellow leaders and releasing responsibility to them." Genuine ministers equip, mobilize, and entrust many people with significant responsibilities.

The pastor-equipper model makes it possible for the pastor to take over the important task of teaching and discipleship. Equipping is a process of teaching. Teaching is essential for the growth and maturation of the church members. When pastors adopt this model, discipleship will be the result. Pastors should help believers to grow, teach obedience, and prepare them to fulfill the great commission (Matt 28:18-20). This preparation is vital in the discipleship process and is an integrating element in all forms of Christian ministry. ${ }^{3}$

Teaching is the basic dynamic method in spiritual discipline; it also integrates church members into ministry. The real purpose of teaching is to focus on the growth of people in the process. It empowers people to do dynamic service for the church.

Showing an interest in teaching and equipping church members generates a trust relationship between pastor and members while the pastor's leadership is strengthened. Everyone is rewarded when members are guided into active and meaningful avenues of Christian service.

'Carl F. George, Prepare Your Church for the Future (Grand Rapids: Fleming H. Revell, 1996), 120.

${ }^{2}$ Cousins, Anderson, and DeKruyter, 115.

${ }^{3}$ Lucien E. Coleman, "The Ministry of Teaching," in Formation for Christian Ministry, ed. Anne Davis and Wade Rowatt, Jr. (Louisville, KY: Review and Expositor, 1981), 222-225. 
The last reason for being a pastor-equipper is that equipping is always necessary. The following reasons could be given: (1) new members need training; (2) training provides new knowledge and tools for all members; (3) equipping introduces new and better methods to use and implement; (4) new church officers need training; (5) new target groups or communities need to be reached, and (6) the work of equipping and perfecting the saints takes an entire lifetime. ${ }^{1}$

Writing this project has been a significant learning experience for me as it enlarges my understanding of my own role as a pastor and the role that every SDA believer plays as a member of Christ's body. The pastoral role has shifted from the super-pastor figure that was responsible for everything in the church to someone who inspires, equips, and calls church members to be involved in productive ministry. The pastor's task is equipping the saints for the carrying out of the great commission given by Christ to His followers, to carry the Good News of the gospel to the ends of the earth.

After this analysis of the subjects dealt with in this chapter, I will deal with the more practical aspects of sharing the knowledge acquired. A framework for mobilizing laity into ministry according to spiritual gifts is presented in chapters 4 and 5 .

${ }^{1}$ Norton, Class notes for CHMN 664. 


\section{CHAPTER 4}

\section{THE PROGRAM, PART I: PLANNING PROCESS}

\section{Mobilize Laity into Ministry}

Mobilizing the laity is an important element for enhancing pastoral work in multi-church districts. Of course, many other areas are also crucial in enhancing pastoral work in multi-church districts. However, this program deals with those that can be the basis of improvement in every aspect of church life, facilitating the fulfillment of the mission of the church and contributing to a more productive and satisfactory pastoral ministry in Brazil. Mobilizing church members into ministry according to their gifts, talents, and abilities is the key to reaching such a purpose.

Although the SDA Church in most parts of Brazil is growing fast, and the growth of the church is related to lay participation, still a great percentage of people are not involved in ministry. Churches with little member participation are compared with a soccer game by Ray Fulenwider: 22 people on the field tired out and hundreds of people in the stands as spectators who need exercise. In fact, Douglas Kilcher observes that "in many churches, 20 percent of the members are doing 80 percent of the work." ${ }^{2}$ This lack

'Ray Fulenwider, The Servant-Driven Church: Releasing Every Member for Ministry (Joplin, MO: College, 1997), 143.

${ }^{2}$ Douglas R. Kilcher, "The Minister as an Equipper," in The Adventist Minister, ed. C. R. Holmes and D. R. Kilcher (Berrien Springs, MI: Andrews University,1991), 99. 
of participation might be the result of having pastor-centered churches, the pastor's failure to equip the body, or lack of spiritual motivation.

In the biblical concept of the priesthood of all believers and in spiritual gifts a district pastor can find great motivation to implement this suggested program. The pastor needs to keep in mind that God wants His church to grow. In order for God's purpose to be reached, He has given each member of His body gifts and talents. These gifts and talents have been given so that the church can grow spiritually and numerically. The effective growth of the church is proportional to the number of members who are involved in the growth process in a meaningful way. As the ultimate purpose of pastoral work is the growth of the body--the church, the pastor should work towards the development of this program in multi-church districts.

It is important to emphasize that this is not another structure for SDA churches in Brazil. The emphasis of this program is to creatively improve the church departments that already exist in Brazil. The purpose is to prepare a great voluntecr team to work in a variety of ministries, where gifted people are equipped, trained, and motivated by their pastors to work for the Lord. The district pastors would then be able to do their job with joy and more productively.

\section{Effective Pastoral Work and Lay Involvement}

The mobilization of the laity into ministry depends in great measure on the pastors' ability to recognize that they cannot do all the work alone and that they need to empower others to help with the work. Wagner warns that no pastor alone, regardless of 
how gifted he is, can be effective in church growth.' Greg Ogden agrees with Wagner's concept and points out that "the biblical emphasis is not on the omni-competent pastor, but on a multi-gifted body."2 He further declares that "the pastor's role is not to guard ministry jealously for himself, but instead to turn the spotlight on this multi-gifted body. In the process, God's people are discovering that in fact they are gifted to act." ${ }^{13}$

Effective pastoral ministry demands total involvement of the laity in the ministry of the church. They need to be motivated and equipped to work in diversified ministrics, according to their gifts. Lay ministry enables members to accomplish the mission of the church and, at the same time, to find personal fulfillment through the ministry in which they are involved. If the pastor really wants to do ministry according to the biblical foundation, the laity needs to be "deployed for ministry." emphasizes that "the greatest need of the church is the release of members for ministry." Thom Rainer points out that "one of the most exciting principles of church growth is unleashing laity to do the work of ministry."

Mark Finley presents lay involvement as a great weapon for pastoral ministry. He says that when pastors work to get a well-mobilized and carefully organized laity while

'Wagner, Your Church Can Grow, 56-57.

${ }^{2}$ Greg Ogden, The New Reformation: Returning the Ministry to the People of God (Grand Rapids: Zondervan, 1990), 75.

${ }^{3}$ Ibid., 21.

${ }^{4}$ Wagner, Your Church Can Grow, 63-77.

${ }^{5}$ Warren, 365 .

${ }^{6}$ Rainer, 203. 
creating a diversified ministry, giving church members the opportunity to use their gifts, the church is built up and the members become a unified force, appealing to all segments of the community.' Monte Sahlin, also emphasizing the importance of lay ministry, says that the great advantage for pastoral work is that the pastor is building not only a pastorate based on his/her talent and good performance, but effective and permanent ministrics. $^{2}$

Robert Logan adds some important aspects pastors must recognize if they want to mobilize laity for ministry.

1. God gives equipping gifts for a diversity of types of ministry.

2. Every member can discover those gifts and use them in a ministry both for personal fulfillment and for building up the body of Christ.

3. The church body is designed to function as a mutually dependent team, discovering and fulfilling together the assignment that God has given them. ${ }^{3}$

District pastors should often ask themselves: What do I really need to do in this church that they are not able to do for themselves? Important questions the pastor should ask the members are (1) What can you accomplish? (2) What is your spiritual gift or talent? (3) What is your ministry in this church? Based on these questions, pastoral work can be developed in multi-church districts. To answer these questions, pastoral work should be developed around the principle of the priesthood of all believers and

'Mark A. Finley, "Vital Signs of a Healthy Church," Ministry, May 1982, 5.

${ }^{2}$ Sahlin, 155.

${ }^{3}$ Robert E. Logan, Beyond Church Growth (Tarrytown, NY: Fleming H. Revell, 1989), 162. 
spiritual gifts. How to develop a program to mobilize church members to work side by side with the district pastor to fulfill God's mission is described in the following pages.

This program presents some principles that will serve as a basis for action. Of course, principles cannot be interpreted as a method. Principles are universal, but methods can apply only in a specific context. This program provides concepts and ideas that the district pastor needs to adapt according to the reality of each congregation. It may be implemented when the pastor starts a new district or even if the pastor is already in the district. The beginning of the year is a good time to get started. There are some important steps in cach phase in the process of implementing this program. The size of the church and other factors determine how the pastor will follow these steps. Making lay participation an effective reality involves several action steps. The starting point should be the district pastor.

\section{Personal Philosophy of Ministry}

As the pastor assumes his role as spiritual leader and equipper of the saints, he needs to adopt it as a personal philosophy of ministry. The starting point is creating more involvement among the laity by teaching them to use their gifts and talents in the ministry of the church. Here pastors must answer such questions as, How do the Scriptures and the Spirit of Prophecy define my responsibilities? How does the SDA Church understand pastoral ministry? What is God's purpose in calling pastors? How has God gifted and equipped me in distinctive ways for the ministry? A personal philosophy of ministry helps pastors to make decisions about every important facet of ministry: 
management of time, development of relationships, leadership style, preaching, family responsibility, and so forth.

Mobilizing lay people in diversified ministries and developing leaders to do the work is not easy. The road to achieving a fully mobilized laity is long and difficult, but it can be traveled one step at a time.' The pastor needs a strong philosophy of ministry based on the biblical teaching of the pricsthood of all belicvers and on spiritual gifts, and he must be willing to pay the price this enterprise requires.

Usually, pastors in Brazil expect immediate results. If the pastor wants to implement this program, he should not expect results and fruits immediately. They may come only after some time. However; the results could be more effective. Undertaking the equipping program requires pastors to prioritize their ministry around the concept of "equipping the saints for ministry." Placing members in a meaningful ministry becomes the greatest goal of the pastorate.

The program suggested in this chapter and in chapter 5 has the purpose of helping pastors to develop a ministry that puts people first and empowers them to become radical disciples of Jesus Christ. To establish this program, pastors need to assume their roles as spiritual leaders and equippers of the church. They must lead their congregations to understand the biblical concept of the priesthood of all believers and help to discover, develop, and utilize gifts designed for various ministries.

'Logan, 163. 


\section{Planning Process to Mobilize Laity into Ministry}

After accepting their role as equippers of the saints for ministry and having a clear understanding of the biblical teaching of the priesthood of all believers and of spiritual gifts, pastors need to establish in each church of their district an adequate plan to mobilize church members to do the work according to their talents and gifts. The district pastor cannot underestimate the importance of planning. It is well worth the time invested. "If failing to plan is planning to fail," planning significantly raises the probability of church growth and non-planning reduces it. ${ }^{2}$ Prayer and sceking God's guidance should pervade every phase of the planning process. Proverbs gives wise counsel: "Commit your work to the Lord, and your plans will be established" (Prov 16:3).

\section{Create an Appropriate Climate}

Several steps should be followed. First, the pastor should start by creating an appropriate climate. When the pastor devotes energy to the spiritual development of church members, they become more open to God's call for ministry and are able to use their spiritual gifts to help the church fulfill its mission. They not only minister through programs of the church; they also seek new ways to minister to others.

Before members are willing to accept their ministering roles and to set challenging goals for themselves, they must have some sense that God is with them--that He will help them to be effective co-workers in His cause. Part of this new spirit

'John W. Ellas, Measuring Church Growth (Houston, TX: Center for Church Growth, 1997), 117.

${ }^{2}$ C. Kirk Hadaway, Church Growth Principles: Separating Fact from Fiction (Nashville: Broadman, 1991), 111. 
involves a rcorientation of congregational priorities. Prayer can play a major role in this reorientation by focusing on the true purpose of the church.'

One practical result of this spiritual environment is the creation of an atmosphere where ministry or service is valued and significant. The laity begin to see themselves as part of a vital enterprise, one that is moving toward definite goals, one that has an impact on people's lives. As described by Douglas Johnson, "lay-people in these churches, tend to have a positive attitude about themselves and their church, want to be leaders in the church for the sake of witness and service. They prepare for leadership, and they take their positions scriously."

This new atmosphere also impacts the attitudes of those likely to be skeptical and critical of any new program of the church. They may even come to realize that their negative opinions are no longer valued and that there may be something positive about the course the church is taking.

\section{Clarify the Purpose and Mission of the Church}

Church members need to be acquainted with the purpose of the church. Neil Wiseman declares that "unless church members and their leaders have a precise understanding of the purpose, they will become content with mere maintenance of the church as an institution. The purpose of the church becomes clear when the mission is

'Ibid., 164-165. 49.

${ }^{2}$ Douglas Johnson, Vitality Means Church Growth (Nashville: Abingdon, 1989), 
understood."' Nancy Vyhmeister stresses that pastors need to lead church members to understand and to carry out the mission of the church. She says, "A sense of mission focuses on an awareness of direction, purpose, and reason for the existence of the SDA Church."2 Writing about the missionary nature and purpose of the church, Ellen White points out that "the church is God's appointed agency for the salvation of men."

C. Peter Wagner, who continued the work started by Donald McGavran, says that the basis for understanding the purpose and the mission of the church is found in Matt 28:18-20. This is the biblical basis and thcological reason for the existence of the church. The main purpose and mission of the church is the salvation of human beings through Christ to the glory of God. ${ }^{4}$ Rick Warren's book, The Purpose-Driven Church, defines the major purposes of the church. He notes that in Jesus' statements of the great commandment (Matt 22:37-40) and the great commission (Matt 28:19-20), one finds the major purpose and mission of the church, consisting of five elements.

1. Love the Lord with all your heart. The church exists to glorify and worship God.

2. Love your neighbor as yourself. The church exists to minister to and to serve people.

'Wiseman, 17.

${ }^{2}$ Nancy J. Vyhmeister, Class notes for MSSN 560 Mission to the World, Andrews University, Berrien Springs, MI, July 1997.

${ }^{3}$ White, The Acts of the Apostles, 9. 50.

${ }^{4}$ C. Peter Wagner, Strategies for Church Growth (Ventura, CA: Regal, 1989), 49- 
3. "Go and make disciples." These were Jesus' last words to His disciples, words about evangelism (Matt 28:19-20; Acts 1:8). The goal of evangelism is to make disciples.

4. Baptize. By baptism people are accepted into the fellowship of belicvers and as part of Christ's body. As Christians we are called to belong, not just to believe.

5. Teach obedience. The Greek text of the great commission has three presentparticiple verbs: going, baptizing, and tcaching. Each is part of the command to make disciples. Discipleship involves the process of helping people to grow in Christ, a process that continues throughout all life. It exists not only to reach people but also to teach them all things that God wants them to obey, develops them toward Christlike maturity and equips them for their ministry in the church.'

Floyd Bresee, an Adventist leader, analyzed these elements of the Great Commission that summarize the mission of the church.

Neither going, baptizing, nor teaching are ends in themselves; they are all means to the end of discipling. Jesus said the church's business is making disciples. To make disciples, we need to go. We need to baptize. We need to teach. But these are not our business. If these become ends in themselves, if we ever concentrate on any of them rather than on making disciples, we will soon be out of business. ${ }^{2}$

Charles Van Engen brings some insights regarding the church's purpose and reason for being through four well-known NT words: koinōnia, kerygma, diakonia, and martyria. Through koinonia the church practices the true love for one another and the fellowship that flows is based on respect, care, and a healthy interpersonal relationship

\footnotetext{
${ }^{'}$ Warren, 103-107.

2Floyd Bresee, “Keep What You Reap," Ministry, April 1990, 23.
} 
among believers (John 13:34). Through kerygma the church proclaims and confesses Jesus as Savior and Lord (Col 1:15-20). Through diakonia the church is an extension of Christ's ministry and its mission is to serve one another (John 13:16). Through martyria the church is a dynamic group of witnessing disciples for Christ. God's missionary church witnesses to the fact that Jesus is alive and that He is the head of the body (Acts $1: 8){ }^{1}$

\section{Redefine the Concept of Ministry}

After creating understanding about the church's purpose, another important part of the planning process is to review the concept of ministry, both in the church and in daily life. For this one must resort to the Bible.

The NT fundamental to ministry is the concept of service. This concept is primarily formed by three Greek words: diakoneō, diakonos, and diakonia. Sixty-eight times these words are translated "ministering," "minister," "ministry," or "ministration."2 The pastor needs to create the understanding that for Christians there is only one calling, the universal calling to ministry.

The Greek term from which we get the word ministry is diakonia which usually means "to scrve." In the NT, ministry is derived from Christ. Stott argues that "all

'Charles Van Engen, God's Missionary People: Rethinking the Purpose of the Local Church (Grand Rapids: Baker, 1991), 89-99.

${ }^{2}$ Hermann W. Beyer, "Diakoneō, Diakonia, Diakonos," Theological Dictionary of the New Testament (TDNT) (Grand Rapids: Eerdmans, 1964-1974), 2:81. 
Christian ministry is derived from Christ."' Ray Anderson asserts that the ministry of the church is God's ministry. Therefore, it "is determined and set forth by God's own ministry of revelation and reconciliation in the world. ${ }^{22}$ For George Hunter, Jesus' ministry must be presented as a model for Christian ministry. He states: "Our Lord reported that He came not to be served, but to serve, and He calls His church to this type of ministry. ${ }^{13}$ It is the ultimate purpose of all church ministries to serve.

Ellen White comments that "long has God waited for the spirit of service to take possession of the whole church, so that every one shall be working for Him according to his ability." When the atmosphere of loving and sacrificial service permeates the church, and when church members grasp a clear concept of church ministry, a great step toward lay involvement will be achieved. All the finest plans and strategies to involve laity in ministry will have a limited effect or none at all if the spirit of service is not found in the churches. This spirit of service is created by a heartfelt love for the Lord demonstrated by service for others. Gary McIntosh points out that all strategies, when

'John Stott, The Contemporary Christian (Downers Grove, IL: InterVarsity, 1992), 280.

${ }^{2}$ Ray S. Anderson, "A Theology for Ministry," in Theological Foundations for Ministry, ed. R. S. Anderson (Grand Rapids: Eerdmans, 1979), 7.

${ }^{3}$ George G. Hunter III, To Spread the Power of Church Growth in the Wesleyan Spirit (Nashville: Abingdon, 1988), 26.

${ }^{4}$ White, The Acts of the Apostles, 111. 
merely at the technical and intellectual level, will fail if they do not appeal to the heart of members enough to move them into sacrificial service. ${ }^{1}$

The concept of ministry can be summarized under the following seven axioms.

1. All ministries in the church are Christ's ministry and must be centralized in Him.

2. All Christians are called to incarnate this ministry in all areas of their lives.

3. Christ's ministry is incarnated in diverse functions and reflects a wide variety of gifts. Among these there is no hicrarchy of valuc; no one ministry is worth more than any other. Thus, the church must provide multiple options for ministry and be adaptable to people creating new kinds of ministries which utilize their gifts. ${ }^{2}$

4. Christ's ministry is to persons. Organizational structures and processes can be instruments of ministry. They can support, affirm, and encourage those who are involved. Church members must be affirmed in their ministries, equipped to better carry them out, and supported in various ways by the congregation. ${ }^{3}$

5. Any kind of ministry, however, must be organized, so leadership is always needed. Leadership should be delegated according to individual gifts, skills, and abilities.

\footnotetext{
'Gary L. McIntosh, The Exodus Principle (Nashville: Broadman and Holman, 1995), 5.

${ }^{2}$ Burrill, 90.

${ }^{3}$ William E. Diehl, Ministry in Daily Life: A Practical Guide for Congregations (New York: Alban Institute, 1996) 9.
} 
6. Ministry focuses on the needs of the church and of the community. Every ministry must be an evangelistic channel through which the church fulfills its mission and purpose.

7. The real purpose of the church's ministrics is to focus on people in the maturing process. Barna points out that "ministry is not about programs; ministry is about people. The focus is to be on people, through meaningful relationships."1

\section{Ministry in the Church}

In Brazil, the word cargo, "charge," is used for a church appointment to office. This suggests a load to be carried, a position to be held; the word is used to designate a public function. Members must be aware that they are appointed to more than a cargo or function. The appointment is a ministry that the church entrusts to them according to their gifts.

Two common errors often occur in pastoral work. First, every year the pastor and nominating committee select and enlist persons for church leadership positions. Many pastors find this the most stressful time of the year because in too many churches there are fights for authority cargos. In other churches there are not enough volunteers to fill all the functions suggested by the Church Manual. Nominating committees in other churches choose just anybody to fill the positions, and the committees feel satisfied for having "full-filled" their part of the job. The worst problem is when the whole process becomes a mechanical exercise of pastoral function without any consideration as to

'Barna, User Friendly Churches, 42. 
whether the member is gifted for the appointed activity. As a result, many serve in a position for which they are not equipped and for which they have no passion.

In most cases, the majority of the people nominated do not know why they were chosen for the job. Most do not know they have been nominated until they hear their name read on Sabbath morning. Burrill, commenting on similar circumstanees, notes that "in this structure many times people are kept out of ministry rather than placed into ministry. As a result, many times people are given jobs for which they are not gifted. This results in poor performance, frustration, and sometimes resignation from all church jobs."1

The second mistake is that the pastor and church leadership have no plan to train and equip those who are chosen. This fosters insecurity on the part of those who have been appointed. Many end up being disappointed because they realize they are not gifted for a certain "job" and finally lose interest in becoming involved in the leadership of the church. On the other hand, some are placed in the same function for many years and do not grow in their experience as leaders. Another aspect in this system of choosing officers for the church is that in many cases the process is just reelection. This often inhibits the possible formation of new leadership with new enthusiasm and new initiatives.

McIntosh emphasizes that the spirit of service reaches people only if they have been empowered. Empowerment is an active term; it gives authority and responsibility from the one in charge to a subordinate. Empowerment in the church takes place when

${ }^{'}$ Burrill, 91. 
pastors and church leaders allow those who are followers to participate or act according to their gifts, talents, and abilities. The role of pastors and leaders is not to control those under them but to empower others by granting them permission to become engaged in ministry.'

\section{Ministry in Daily Life}

Church members also need to be taught that ministry occurs not only in the church, but--and more often--in the world. Many times church leaders have encouraged the view that lay people are engaging in ministry only when they serve the local congregation and the structures of the church. Burrill points out that ministry is not confined to the church building or to the sacred hours of the Sabbath. Lay ministry involves the entire life of the Christian. The most meaningful ministry for church members may happen in a secular environment during the week. In this view of ministry, lay people will come to see that their ministry is concerned primarily with the activities of everyday life. ${ }^{2}$

William Dichl lists four areas of daily ministry: "occupation, family, community, and church." ${ }^{33}$ Occupation means all activities that involve people professionally; family refers to all with whom one has an ongoing relationship; community is where one lives;

'Ibid., 6.

${ }^{2}$ Ibid., 91 .

${ }^{3}$ Diehl, 13 . 
and church involves the local congregation, the regional church structure, and the Christian church at large. ${ }^{1}$

Since many church members do not see themselves in ministry or sense that God has called them into ministry, they go through life totally missing the glorious truth that they are ministers, channels for God's action in the world. ${ }^{2}$ It is fundamental for pastors to lead their members to achieve a clear understanding of what it means to be a minister in the church and the world.

To summarize, the church is not to be served by God but to serve God and to be in God's service. Ministry, then, is the nature and mission of the church. When pastors and church members understand that any office or function of the church is a ministry, and that ministry is extensive to the daily life of believers, the church could fulfill its purpose as God's missionary enterprise.

Formulate a Philosophy of Ministry and Statement of Mission

The next step in the plan to mobilize church members for ministry is to establish in a statement of mission for each church in the district. Most Seventh-day Adventists can give a fairly clear statement of the gospel commission. However, preparing a statement of mission and the philosophy of ministry at the local church level is somewhat

${ }^{1}$ Ibid.

${ }^{2}$ Ibid., 17. 
more difficult.' Wagner observes that "the first thing a church that wants to grow needs to know is its philosophy of ministry."2

Developing a mission statement that summarizes the philosophy of ministry in each church improves goal setting and establishes an identity and purpose among the members. Fulenwider says that it "provides a road map for the local congregation." Each congregation is unique with a potential for ministry according to the diverse gifts and talents bestowed in a variety of ways. No congregation can be expected to reach each and every person. Nevertheless, in terms of active and deliberate ministry, a congregation will be more effective if it works in areas for which it is equipped. ${ }^{+}$

A philosophy of ministry improves self-identity. It is the focus for all the programs and activities of the church. It helps in the planning process, gives substance to everything the church does, and determines whether to embrace a particular ministry task. It also helps to avoid anything that is not related to the mission of the church.

The development of a philosophy of ministry is the work of the pastor and church leaders. However, it is important for them to involve the whole congregation and to get their total support. To create the mission statement the pastor should work with church leaders and a significant group that must represent the whole church. In the first meeting

'George E. Knowles, How to Help Your Church Grow (Silver Spring, MD: General Conference of SDA, 1997), 20.

${ }^{2}$ Wagner, Your Church Can Grow, 92-93.

${ }^{3}$ Fulenwider, 35 .

${ }^{4}$ Dean F. Brookes, "Growth in Australian Churches" (D.Min. dissertation, Fuller Theological Seminary, 1990), 90-93. 
leaders brainstorm, writing down their ideas to express the mission and purpose of that specific church. In small groups they discuss these ideas and each group summarizes the lists the five ideas it considers most important. In the second meeting, on the basis of the work of the groups, the leaders choose the mission statement that represents their understanding of what the church should be and do.

The philosophy of ministry, first of all, needs to be in harmony with the Bible and the Spirit of Prophecy and be accepted by the pastor and members. Second, it must be explicit and specific. It needs to be simple, clear, and narrowly defined. It should avoid ambiguous language. It must set a clear direction for the church and become the basis on which short-term and long-term goals are set. It must be written out so it can be printed and circulated in the church programs or perhaps appear permanently on banners hung in the church building. It can be summarized in a few words, in terms everyone in the congregation can relate to and communicate to others. Eventually, it will become a conviction. The members will believe it to be a clear statement of their life and ministry. Third, it needs to be measurable and open to regular review. It should help the congregation to evaluate whether or not it is fulfilling its mission and purpose. It should help to review, revise, and improve everything the church does. Finally, it must be attainable. It needs to be something that the church can accomplish with the grace and power of God.'

A good example of a philosophy of ministry and mission statement is one David Newman developed with his church, the Damascus Grace Fellowship. Their philosophy

'Adapted from Rick Warren, as quoted in Fulenwider, 35. 
of ministry deals with three important ingredients: values, mission, and vision. Values, according to Newman, tell what the church is; mission tells what it does and what it is about; and vision tells where the church is going. Newman explains that mission means preparing whole persons to preach the whole gospel to the whole world, wholly to please God. Values proclaim a church that values God's word, that values the body of Christ, that values service, a servant spirit, and excellence in all that it does. Vision shows the willingness of the church to be a ministry-training institution uniquely suited for the needs and challenges of the twenty-first century.' Their mission statement reads: "We will love people and organize ourselves to value and encourage others, especially youth and the unchurched, to become disciples of Jesus Christ."

Other SDA churches have create or adopted their own mission statement. The statement from Pioneer Memorial Church, Berrien Springs, Michigan, reads: "Forward on our knees--readying our lives and reaching our world for the imminent return of Jesus." The All Nations Seventh-day Adventist Church, also of Berrien Springs, Michigan, reads: "The All Nations Seventh-day Adventist Church is a fellowship of believers from diverse cultures and ethnic groups united in Christ, their Savior and Lord. This Church sees its mission as a continuation of Jesus' ministry of compassion through utilizing the various gifts of the Spirit as manifested among all its members."

\footnotetext{
'Newman, Class outline for CHMN 623 Innovative Evangelism, 35-39. ${ }^{2}$ Ibid.

${ }^{3}$ Pioneer Memorial Church, Bulletin, February 1999, Berrien Springs, MI.

${ }^{4}$ All Nations SDA Church, Bulletin, February 1999, Berrien Springs, MI.
} 
According to Rick Warren, four areas of church life should be considered in order to establish a good mission statement. The first is the image of the church in the community. How will the community view the mission statement? Will it help the church to be respected or will it build walls between the community and church? Second, it must meet the needs of members. Third, the mission statement must reflect the importance of training and preparing leadership and members for church ministry. Fourth, the mission statement needs to lead church members to commit their money, time, gifts, and talents to fullill the mission of the church.'

The suggestions presented in this chapter are fundamental for the implementation of the whole program. The size of the church and other factors will determine how long it will take to bring such preparation to the church. The most important factor is not time, but whether or not these suggestions are taken into account for the effectiveness of this program.

The ultimate purpose of this program is to help pastors to develop a more effective ministry in multi-church districts by mobilizing laity into ministry. Chapter 5 presents the steps that are fundamental to the implementation of this program.

'Warren, in Fulenwider, 35. 


\section{CHAPTER 5}

\section{THE PROGRAM, PART II: THE EQUIPPING AND IMPLEMENTATION PROCESS}

It is a pastor's great dream to have every member using his/her gifts and talents to the glory of God to build up the body of Christ. Unfortunately, this does not happen automatically. It takes a lot of prayer, work, willingness, and sacrifice for those who are involved in this dream. While the implementation of this dream involves every leader and church member, the pastor is the key for making this dream come true. The pastor needs to help people discover their gifts by teaching what spiritual gifts are and by giving church members the opportunity to explore various possibilities of ministry.

As the majority of districts in Brazil have many churches and companies of different sizes and potential for growth, the pastor may start with the church that is more open to the implementation of this program. This church could then be a model for other churches of the district. After doing the preparation described in chapter 4 , the following action steps are basic to the program. 


\title{
Presenting Spiritual Gifts
}

\begin{abstract}
Step 1
Create understanding of the biblical concepts of the priesthood of all believers and spiritual gifts. This lirst step is fundamental because it presents the biblical foundation for lay involvement in ministry. It also defines the role of the pastors and the role of the laity.
\end{abstract}

The pastor should start the program with the church board and then extend it to the whole congregation. It may take several meetings with the church board to be sure the members of the board understand and accept this biblical concept of ministry and the importance of mobilizing church members in mcaningful ministry. The next natural step is to present the plan to the whole congregation. Before that presentation, the church board should appoint what I like to call "Spiritual Gifts Coordinating Committee" (hereafter referred to as SGCC).

In some churches, the elders could be members of the SGCC. The size of the church determines the size of this committce. The role of this committee is extremely important; its members must work closely with the pastor to implement each step of this program. Although the church board could delegate some decision making to this committee, it is not the purpose of this committee to replace the authority of the church board. The work of this committee must be in harmony with the interest of the church as a whole and have the total support of the church board. The SGCC must work hard to help the pastor in each phase of this program. The emphasis on teamwork is fundamental at this stage. 
A week of prayer could be the starting point where some inspiring topics on the priesthood of all believers and spiritual gifts can be presented to the church at large. The material presented in chapter 2 of this study could be helpful during this week. After an awareness is created, the pastor could invite the members join in for the next step.

\section{Step 2}

I call this step the "discovery phase." The whole church should be motivated to attend a weekly meeting. The church facilities or a district Adventist school may be the best place for the meetings. The schedule should consider the most convenient time for the most church members. In some places, Saturday afternoon works best; in other places, one evening during the weck or Wednesday prayer meeting is best. Pastors need to set a time that is agreeable to their congregation. The participants are given two-hour, interactive classes in a dynamic teaching-and-learning style and also assignments. The pastor should avoid lecture-style sessions and let the participants work out the best style for them. The discovery step is divided into three phases.

\section{Discovery Phase 1}

Discovery phase 1 has three sections. The first gives an overview of the course of the seminar and provides biblical and Spirit of Prophecy background for lay ministry. The second presents a biblical review of spiritual gifts. The third defines the role of the pastor and the role of the laity in the light of the priesthood of all believers and spiritual gifts. 


\section{Discovery Phase 2}

Discovery phase 2 also has three sections: In the first, members are asked to record information about gifts, personality, experience, and spiritual maturity. Members are also asked to complete a questionnaire about family, employment, and their vision for the church and ministry involvement.

The second section of the discovery phase explores spiritual gifts. Assignments include reading definitions of spiritual gifts and Scripture references, taking a spiritualgifts inventory, and having someone else take the inventory for the member. In addition there is an exercise on identifying gifts in action. ${ }^{\prime}$

In the third section, the students look at the other resources that can be used for the Lord. These include an inventory of talents, abilities, skills, roles, and offices. In addition, temperament and those areas of ministry to which one finds oneself strongly attracted are explored. Assignments include surveys for ministry interest and a personal schedule with available time to work as volunteers in lay ministry.

\section{Discovery Phase 3}

Discovery phase 3 involves two sections. The first shows how to put into practice what has been discovered. It includes an overview of the church's ministry and lists specific places of service according to whatever spiritual gifts, talents, and abilities one

'See Zackrison, Practical Spiritual Gifts, 111-125. 
might have. This is followed by a personal interview with each participant of the program. $^{\prime}$

The SGCC assists the pastor by interviewing every member who filled out a survey called "My Gift Is to Serve." In this survey, members express their opinions about their gifts, abilities, and talents, and the ministry they wish to serve. This one-on-one meeting is important to clarify what has been learned, the areas of ministry each person shows an interest in, the time available for training, the kind of involvement cach prefers in that ministry, and the action plan.

The interview is a great opportunity to motivate potential leaders and to lead those already involved in ministry to match their spiritual gifts to work for the church with renewed interest. In this personal contact, it is important to remind church members of SDA doctrines and the importance of following them. This interview needs to be done with skill in order to motivate members to recognize their gifts and to recruit them to work in the multifaceted ministries of the church.

\section{Following Jesus' Model}

Jesus' model in preparing His disciples should be closely followed by the modern pastor. Jesus performed basic aspects of the ministry such as preaching, healing, and teaching, but most of His time was spent with His twelve disciples. Once the pastor makes the decision to unleash his church by equipping and freeing others to serve, he

'Examples of spiritual-gifts inventories that could be used are: Wagner, Your Spiritual Gifts Can Help Your Church Growth, 238-259 and Zackrison, Practical Spiritual Gifts, 126-139. 
must develop a strategy for doing just what Jesus did in the preparation of the Twelve. Equipping equals multiplication of results.

When Jesus called His disciples, He said, "Come, follow me, and I will make you fishers of men" (Matt 4:19). In this call, one learns three important principles of leadership. The first indicates that Christian leadership can lead people from the kingdom of darkness into the kingdom of light, from the bondage of sin into the real freedom of the kingdom of God. The second principle is that leaders are made, not born-leadership must be developed. Jesus called disciples because He wanted them to follow His leadership style. The third is the principle of reproduction. Jesus called a few men for special training. His plan was to equip a team of followers to share in His work (Matt 4:19). Jesus not only prayed (Matt 9:38) for more workers, He undertook a decided effort to train and prepare them to minister to others. During the period of training, Jesus developed His disciples' potential to become apostles. They were so trained that Jesus could send them forth as apostles and later to multiply other disciples (Matt 28:18-20).'

In three and a half years Jesus used a variety of methods to equip His disciples; these could be adopted as leadership-development patterns. Robert Coleman presents eight principles Jesus used in equipping the disciples.

1. Selection: Jesus selected a band of disciples from among His followers to be trained more effectively (Matt 4:19).

2. Association: Jesus lived with His disciples in a community and they followed Him wherever He went. He spent much of His time teaching them (Matt 9:35; 10:1).

\footnotetext{
${ }^{1}$ Wallace Arthur Alcorn, "The Biblical Concept of Discipleship as Education for Ministry" (Ph.D.dissertation, New York University School of Education, 1974), 123-124.
} 
3. Consecration: Jesus required them to obey. Obeying Him is the proof of trusting and loving Him (John 14:15).

4. Imparting: Jesus not only asked them to obey, but He demonstrated how He loved them (John 10:11).

5. Demonstration: During His life with the disciples Jesus showed them His supreme character, His attitude toward the people in ministry. The disciples learned from Jesus by secing how He acted (Matt 10:5).

6. Delegation: Jesus not only taught and demonstrated how to scrve, He also assigned the disciples to work, giving them an opportunity to practice what they had learned (Matt 10:16-23).

7. Supervision: Jesus also evaluated the disciples' ministry and corrected them, so they could be more effective (Mark 9:28-29).

8. Reproduction: The expectation of Jesus in training His disciples was that they could also produce other disciples (John 17:20).'

From the above one can draw the conclusion that the training pattern of Jesus can be summarized as follows: (1) In-life training--Jesus wanted His disciples to live and travel with Him as a community, learning from His daily life and character; (2) In-teaching training--the Gospels present Jesus more as a teacher than as a preacher; ${ }^{2}$ and (3) In-service training--Jesus was very creative in teaching the truth by using a variety of methods. Jesus was rich not only in teaching theory but He was also active in helping

\footnotetext{
'Robert E. Coleman, The Master Plan of Evangelism (Grand Rapids: Fleming H. Revell, 1996), 27-116.

${ }^{2}$ Lucien Coleman, 221-222.
} 
His disciples to learn through practical lessons and services. The theory was followed by practical application.

Michael Youssef concludes that Jesus, in developing leadership in the lives of His disciples, accomplished what pastors, as Christian leaders, should aim for in reproducing future leaders. He says that one characteristic of good leaders is that they prepare others to take over and reproduce themselves. "That's the purpose of training others--to make them leaders who will train others who may also become leaders. Jesus started this by multiplying His physical capacity by twclve."1

\section{Equipping Process}

Equipping is an ongoing process that involves preparation, motivation, and formation of solid leadership. The district pastor cannot neglect this important aspect of mobilizing laity to be ministers and to become strong spiritual leaders in the church.

When the pastor follows the steps that have been presented so far, he may create a healthy awareness about spiritual gifts and a climate of participation and involvement in the church ministry. Church members want to be engaged in the church ministry. It could happen at this point that the pastor would have more volunteers for varied functions of the church than there are offices available. At this moment, the pastor and leaders cannot disappoint those who are willing to work. They need to have the opportunity to use their gifts and talents, and the church has the responsibility to provide

\footnotetext{
'Michael Youssef, The Leadership Style of Jesus (Wheaton, IL: Victor Books, 1986), 163.
} 
those opportunities. The next step in this program is to create new ministries according to the gifts available.

\section{Creating New Ministries}

The full development of this program will result in a network of volunteers who are gifted and equipped to do the ministry of the church. When expanding lay participation, it is possible to enhance interest by creating new ministries and improving the performance and focus of present ministries. New ministries must be formed and developed with due attention to the organizational structure of the SDA Church and the proper administration of programs and people. It is important to use the roles and offices described in the Seventh-day Adventist Church Manual.' This last criterion should be used creatively in the light of the priesthood of all believers and spiritual gifts.

For instance, those who have the gift of teaching could be involved in the Sabbath School ministry, in its different levels, as prescribed in the Church Manual. Many ministries (offices) already exist in the church. The function of the SGCC and the pastor would be to place the gifted people in such ministries. If new ministries are created, they should follow certain criteria.

1. The new ministry must maintain legal, moral, and ethical integrity.

2. The new ministry must be biblically based and doctrinally in agreement with the SDA Church.

3. The new ministry should sense the needs in the church and community.

'See Seventh-day Adventist Church Manual (Hagerstown, MD: Review and Herald, 1995), 41-118. 
4. Gifted people should be available who want to work in such a ministry.

5. Leaders or apprentices can become leaders of these new ministries.

6. A training program should be available to equip these new ministries.

7. The church board shouid be involved in the process to create a more effective ministry.

According to Monte Sahlin, successful ministry in the church has four basic elements. First is targeting ministry. Which target group does the ministry want to reach? Second, goals and written objectives must be established with specific descriptions of expected results. This keeps the ministry moving in the right direction. Third, an operational cost-budget should be set. The church board needs to work out a budget to provide for realistic funding. Fourth, the ministries team is the most important requirement to make ministry work. The director or leader is the key person and he/she needs to develop a teamwork mentality.'

In many churches and companies, people commonly say: "We don't have gifted members for such and such function." This is true in most small congregations, but members should pray that God will send gifted people for the ministries of the church. Logan says that "God raises up gifted leaders in response to our prayer before He asks us to reach out in ministry requiring that leadership." ${ }^{2}$

Bill Easum notes that many times new ministries are not created in the local church because some of the leaders seem to control it. The church is too concentrated on

'Sahlin, 155-168.

${ }^{2} \operatorname{Logan}, 162$. 
policies and denominational structures which hinder the creation of new avenues of service. Easum encourages many local churches to change from a tightly controlled organization to one focused on "permission giving." One of the characteristics of permission-giving local churches is that they "encourage ministry to be developed at any time, any place, by any onc, no matter what."' Although every ministry needs to be in harmony with the purpose of the church, the members need to have the opportunity and freedom to minister.

In order to increase lay involvement, the members not only need to have freedom to minister but also freedom to fail. Leaders must give people the room to fail and to provide encouragement to help them learn from failures. The leader should help them to clarify the specific steps needed to change things for the better. ${ }^{2}$.

\section{Recruiting}

After completing the process of discovering and enlarging the possibilities of new ministries or selecting new approaches for the already-existing ministries, the next step is to recruit volunteers. The pastor and the SGCC should make a list of potential workers. Any satisfactory lay recruitment process must be sensitive not only to the skills of the individual but also to the interests of the ministry volunteer. Recruiting people shows them that they are vital to an important task. The key is to help church members find

'Bill Easum, Sacred Cows Make Gourmet Burgers: Ministry Anytime, Anywhere, by Anyone (Nashville: Abingdon, 1995), 5-6. 1991), 145.

${ }^{2}$ Dann Spader and Gary Mayes, Growing a Healthy Church (Chicago: Moody, 
their place in meaningful avenues of service they feel gifted to perform. When gifts are matched with tasks, people perform better.'

Some guidelines can help the pastor and SGCC to recruit the right people for the right place of service. They should: (1) pray that God will send workers and the Holy Spirit to move people to get involved in ministry; (2) enlist volunteers by personal invitation, not by appeals from the pulpit; (3) explain in detail the need so the appeal will stimulate a proper motive for responding; (4) commit to providing training and assisting in equipping; (5) recruit for the short-term and renew for the long-term; and (6) compliment and encourage as the worker deserves.

Job descriptions are important tools in recruitment. Some members are concerned about their ability to measure up to the task; others may be concerned about making a commitment to something they do not understand. Even experienced leaders moving into a new position need a period of adjustment. Job descriptions should be written for every position in the church. Defined job responsibilities can be used to recruit people when ministrics are available.

James Harvey notes that a "job description is an important management tool, yet many churches neglect them.".3 A job description is a guide as well as an agreement between the worker and church leaders about job expectations. It helps those who want

'Norton, Class notes for CHMN 664.

${ }^{2}$ McIntosh, 49.

${ }^{3}$ Harvey, 85-87. 
to get involved in a ministry to understand what the ministry is and does. Descriptions should be reviewed periodically.

\section{Training}

Training is a fundamental part of the equipping process. The basis of pastoral ministry should be training church members to excel in their specific ministries. A basic and regular training program with the purpose of supporting and equipping them is vital. Time spent in leadership training enables church members to grow and eventually lighten the pastor's workload. The laity must be trained to be ministers, and opportunities for ministry must be created by them and for them. ${ }^{2}$ Burrill points out that "training is the best nurture that can be given to God's people." ${ }^{3}$ Kirk Hadaway defines training in the church as "an interactive process whereby members gain knowledge and skills, and then create their own unique ways of applying what they learned in ministry."

In the equipping process, training is not only something mechanical and technical; it includes motivating, setting goals, nurturing, instructing, exhorting, building up convictions, inspiration, knowledge, skills, and so on. It also includes much practice and continued improvement in light of the feedback received. There is no quick and easy way to become equipped; equipping involves a lifetime, an unalterable purpose to use one's gifts, talents, and abilities for ministry. Training in this context is more than a

\section{'Ibid.}

${ }^{2}$ Shawchuck and Rath, 60 .

${ }^{3}$ Burrill, 52.

${ }^{4}$ Hadaway, 106. 
weekend seminar once a year. It is interactive and an ongoing process that involves strong relationships.'

\section{The Need for Training}

Church members need training for several reasons.

1. To help church officers and committee members understand the purpose of their being elected, why they exist as an organization. If they do not have a complete understanding of their purpose, they probably will never be effective in their functions or ministry. Here, a brief description of the job and its purpose is essential.

2. To understand what to do and how to do it, regardless of ministry opportunities. Once people are matched for these tasks, they need to be trained to be effective. Retraining the members is often necessary, especially in the implementation of a new ministry. Training creates renewed enthusiasm and gives new motivation to work as volunteers. ${ }^{2}$

3. To develop leadership, interpersonal relationships, communication, and technical skills. With the development of these skills, lay leaders will become more and more efficient in performing their duties. The quality of their work will improve, and the church will experience qualitative and quantitative growth.

4. To develop a sense of responsibility and commitment.

'Norton, Class notes for CHMN 664.

${ }^{2}$ Dennis E. Williams and Kenneth O. Gangel, Volunteers for Today's Church: How to Recruit and Retain Workers (Grand Rapids: Baker, 1993), 103. 
5. To provide resources and motivation to get people involved in ministry. People more readily volunteer for church work when they know they will be given the resources to succeed. The fear of failure keeps good people from taking on tough jobs. Good training relieves their uncertaintics regarding their ability to do the job well.'

\section{Training in Multi-Church Districts}

The district pastor in multi-church districts should give two types of training: general skills training and specific training for a given ministry. General training is important for all workers, and should include skills in different areas of ministry, such as spiritual discipline, and personal growth. Specific training is targeted to the particular assignment a person is expected to fill. ${ }^{2}$ Some ministries require professional attention on a continuing basis. In such areas the pastor should ask for professional help to do this training.

When the pastor has many churches and companies in several cities he could divide his district into two or three geographical areas, with a training center in each area for seminar training. The pastor who has several churches and companies in one city could make a system of rotation where the general session occurs in one of the churches or in a different area of the city each quarter. The officers of each congregation are invited to attend general training sections.

'Shawchuck and Rath, 60.

${ }^{2}$ Johnson, Empowering Lay Volunteers, 80-85. 
General training seminars could be a special time for inspiration, orientation, and motivation for the ministries of the church. The seminars should have a time slot for personal testimonies by church members so the people in different churches and companies of the district can hear how others are doing their ministry.

In addition to the general training session, a network of training must provide specific training focused on specific needs of each church and region. This is true especially when new ministries are implemented. Duc to the complexities and peculiarities of every ministry, the needs and skills of each ministry are singular. The leader of music will need skills different from the leader of the deacons. The pastor needs to be prepared to support every church voluntecr in all areas of ministry.

A local training session should take from ninety minutes to two hours, including group discussion, lab learning exercises, and time for review and questions. The pastor's role must be that of a facilitator, not a lecturer. The schedule of meetings should take in consideration time convenience for both the pastor and church member.

Carl George and Robert Logan suggest four steps in the process of teaching: first, "I do, you watch" (modeling and observation); second, "I do, you help" (modeling and participation); third, "you do, I help" (assisting and evaluation); fourth, "you do, I watch" (encouragement).

In this equipping process, the pastor could plan an annual retreat when church officers will receive acknowledgment and recognition for their work, a time when they are encouraged to continue to do their best for the Lord. Plans could be made for the

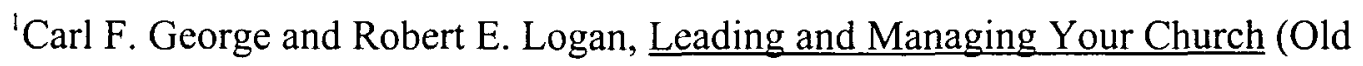
Tappan, NJ: Fleming H. Revell, 1987), 110. 
upcoming year. Mainly, it should be an occasion for church leaders to spend quality time in Christian fellowship.

The pastor needs to consider two important points. First, although the pastors are the key factor to provide training for church officers, they do not need to do everything alone. The pastor needs to delegate tasks. He should find knowledgeable persons to train the laity. Usually, there are people with experience and skills they can share in a specific training program. If no such persons are in one district, laity from other districts and even conference pastors should be invited to train people. What really matters is not who is doing the training, but getting it done. Second, training involves practice; theoretical knowledge and skills must be followed by practice. Church members must have the opportunity to put into action what they have learned in training sessions.

\section{Developing Ministry Leaders}

After all the steps have been followed, the implementation of a gift-based ministry results. Every step is important, but the creation of ministries and placement of church members in ministries according to their gifts and talents depend to a great extent on the availability of potential leaders in the church. Every ministry needs a gifted leader to be the director of the ministry. The implementation of lay ministry based on spiritual gifts requires of the pastor and SGCC to concentrate on preparing leaders to cover each area of the church. The formation of leaders should be the goal of the district pastor. 
Identifying Potential Leaders

John Maxwell illustrates the personality types of leaders in the making: "never be, could be, should be, must be."' Although every person has natural talents and spiritual gifts, not all are gifted for the particular task at hand. A never-be who is directed into an area where he/she is not gifted becomes frustrated, often blames others for his/her lack of success, and eventually burns out. Could-be is a person with the right gifts and abilities but lacking self-discipline. Such a person may be a natural leader, but lacks Christian character.

A should-be is someone with raw talent but without skills for harnessing that ability. Once given help in developing those skills, that person will become what he/she was meant to be. The only thing a must-be lacks is opportunity. He/she has the right gifts, the right skills, and the right attitude. He/she has the drive to be the person he/she was created to be. Once given opportunity and training, he/she will be a blessing to the church. $^{2}$

One of the primary responsibilitics of a district pastor is to identify potential leaders. Though not easy, it is crucial to the implementation of this program. To identify key leaders, the pastor has to do a lot of listening and watching, especially when church members are together. Whose opinions are valued? Whom do other church members quote? Who summarizes group discussions?

'Maxwell, Developing the Leaders Around You, 52-53.

${ }^{2}$ Ibid., 53. 
Maxwell suggests what he calls the five A's to help the district pastor in the task of identifying potential leadership.

1. Assessment of needs: What kind of leader is necessary to place in a specific ministry in the church? Each ministry requires different styles of leadership.

2. Assets on hand: Who are the people already in the church who are available? Availability should be demonstrated on a practical level. Someone who is willing to adjust his/her schedule to the church ministry shows agreement on areas of training and development and ultimately on their own growth.

3. Ability of candidates: Who is able? This involves Christian character, spiritual gifts, natural abilitics, skills, and experience.

4. Attitude of candidates: Who is willing to serve as Jesus did? (Matt 20:26). Who is willing to learn like Paul? (Phil 3:12). The willing person can be corrected and recognizes that he/she needs to learn and improve. Willing people have an appetite for God's word and for becoming effective leaders. Enthusiasm and a positive vision of the church's mission characterize this attitude.

5. Accomplishments of candidates: Who gets things done? This is the kind of person who pays the price to get things done in a Christian spirit and to build up God's people. Such people are motivated and committed to do their best to see the work well done.

'Ibid., 52-53. 


\section{Equipping Current and Potential Leaders}

Once the pastor has identified potential leaders, he needs to begin the work of building them into the leaders they can become. He should look more specifically at how to prepare them for leadership within the congregation. This process is called equipping.

Equipping is similar to training. But I prefer the term equipping because it more accurately describes the process potential leaders must go through. Training is generally focused on specific tasks; for instance, one is training a person to use a copy machine or to operate a computer. Training is only a part of the equipping process. John Maxwell makes it clear.

When I think of equipping a potential leader, I think of preparing an unskilled person to scale a tall mountain peak. His preparation is a process. Certainly he needs to be outfitted with equipment, such as cold-weather clothing, ropes, picks, and spikes. He also needs to be trained how to use that equipment

A mountain climber's preparation, though, involves much more than simply having correct equipment and knowing how to use it. The person must be conditioned physically to prepare him for the difficult climb. He must be trained to be a part of a team. Most important, he must be taught to think like a mountain climber. He needs to be able to look at a peak and see how it is to be conquered. Without going through the complete equipping process, he not only won't make it to the top of the mountain, but he also might find himself stranded on the side of the mountain, freezing to death.'

Equipping is an ongoing process. It is not done in a weekend seminar or in a few hours. It cannot be done using a formula or videotape. Equipping must be tailored to each potential leader. The ideal equipper must impart the vision of the work, evaluate the potential leader, and give him/her the tools he/she needs along the way at the beginning of the journey. ${ }^{2}$

'Ibid., 84.

${ }^{2}$ Ibid. 
In the process of equipping leaders, Melvin Steinbron describes the importance for pastors to consider that "being precedes doing." He says that pastors "need to be equipping at two levels: being and doing. Being focuses on what we are. Doing focuses on what we do."

Maxwell presents three facets of an equipper that can be applied to the district pastor: The equipper is a model, a leader who does the job, does it well, does it right, and does it with consistency. The equipper is a mentor, an advisor who has the vision of the organization and can communicate it to others. The equipper is an empowerer, one who can instill in the potential leader the desire and ability to do the work. He or she is able to lead, tcach, and assess the progress of the person bcing equipped. ${ }^{2}$

\section{Conducting Periodic Equipping Meetings}

The pastor takes certain steps through the whole process. He begins by building a relationship with potential leaders. From that foundation, one can build a program for their development, supervise their progress, empower them to do the job, and finally get them to pass on the legacy. ${ }^{3}$

For three months the meetings should be weekly. Afterwards, the pastor should meet with the leaders of each ministry once a month. To conduct a productive and attractive equipping meeting, the pastor needs to show the leaders how the equipping

'Steinbron, 97.

${ }^{2}$ Maxwell, Developing the Leaders Around You, 84.

${ }^{3}$ Ibid., 92 . 
session empowers them to better perform their jobs. They will leave the meeting feeling positive and ready to work. ${ }^{\prime}$

Effective equipping begins with asking a question about the real needs of the potential leaders. What kind of training program could be implemented to meet those needs? What areas within the church have the greatest growth potential? Do those potential growth areas have the needed leaders to accomplish the task? In the first meetings, the pastor could begin by analyzing the church and its mission and organization. What is the statement of mission and the church's purpose? Other relevant subjects could be spiritual leadership, leadership styles, traits of human nature, and how to achicve teamwork.

To establish purposes for the equipping meeting, the pastor could:

1. Develop a personal relationship with the people whom he is equipping. All good equipping processes begin with personal relationship. ${ }^{2}$ An important element to increase this relationship is to listen.

2. Help people clarify areas where God wants them to grow. This help should not be limited to merely their job performance, but should encompass their character as well. ${ }^{3}$

3. Ask for commitment. Ben Blanchard says, "There is a difference between interest and commitment. When you are interested in doing something, you do it only

'Ibid., 109.

${ }^{2}$ Ibid., 93

${ }^{3}$ Robert E. Logan and Larry Short, Mobilizing for Compassion (Grand Rapids: Fleming H. Revell, 1994), 160. 
when it is convenient. When you are committed to do something you accept no excuses." ${ }^{\text {I }}$ The pastor should equip people who are not merely interested, but equip ones who are committed.

4. Set goals for growth. Equipping involves growth. Leaders need clear objectives set before them if they are to achieve anything of value. A set of goals becomes a map a potential leader can follow in order to grow. Leaders need personal goals that will contribute to the larger goal of the church. The pastor needs to teach and motivate leaders to establish appropriate, attainable, clear, and measurable goals. It is important to put goals in writing. It helps people to review their goals and progress frequently. ${ }^{2}$

Maxwell also suggests elements that should be included in meeting for equipping:

1. Good news. The pastor should start each meeting with one positive note about good things that are happening in the church.

2. Vision. People often lose sight of the vision and purpose that drive the church. An equipping meeting is always the opportunity to rccast that vision.

3. Content. Content will depend on needs. One should try to focus training on priority areas, and orient the training to the people, not the lesson.

4. Administration. This involves covering any congregational and organizational items that give the people a sense of security and encourage their leadership.

'Ben Blanchard, quoted in Maxwell, Developing the Leaders around You, 94.

${ }^{2}$ Maxwell, Developing the Leaders around You, 94. 
5. Empowerment. Although in this meeting many people could be present, equipping is a personal matter. The pastor needs to take time to listen to and connect with the people whom he or she equips.'

An equipping meeting helps potential church leaders to stay on track, to keep growing, and to cncourage them to begin taking responsibility for equipping not only themselves but others who could take part in their ministry team. In this model, the pastor equips potential leaders and these equip others.

\section{Implementing a Gifts-Based Ministry}

After the suggested basics are followed and three months of meetings with potential leaders are completed, the next step is the implementation of the program. First comes organizing.

\section{Organizing}

The pastor and SGCC, with the support of the church board, need to examine the various gifts, talents, and natural abilities that the church has available. Based on this, the essential roles or positions for the ideal functioning of the church to accomplish the ministry goal in the philosophy of ministry need to be evaluated. The pastor should review the basic job description of cach position, what the goals are, what duties the person is expected to fulfill, and the material resources for that ministry. Logan says that "in a healthy church in which a sufficient number of people are using their gifts in

\footnotetext{
'Ibid., 95.
} 
ministry, there must be 60 well-defined roles or tasks for every 100 adults attending worship."

Table 2 shows the kinds of ministry that might be developed from a given gift. It can be helpful to organize gifts into ministries.

\section{Designing a Placement Process}

The placement process involves guiding people with specific gift mixes into ministry. The pastor and the SGCC have some indicators to put the right people in the right place for the right reason. The basic indicators would consider the following five questions:

1. Is the ministry in harmony with a person's spiritual gifts?

2. In addition to spiritual gifts, can the person minister with the variety of natural talents God gave him or her for the purpose of advancing His kingdom?

3. Does the person have passion? Passion is one of the most critical indicators for the person to be more fulfilled in ministry. It has to do with what the person cares about most. Logan points out that "you can do a job because it's a duty, and you might even do it well, but you cannot do it outstandingly if it is not your passion. Passion alone provides motivation for vision and turns dreams into reality." ${ }^{2}$

4. Is the person's personality appropriate to the job? People come in a tremendous variety of personalities. There are introverts or extroverts, organized or spontaneous, thinkers or feelers, up-front or behind-the-scenes, relationship-oriented or task-oriented.

\footnotetext{
'Logan, 164.

${ }^{2}$ Logan and Short, 44.
} 
TABLE 2

GIFTS AND MINISTRY

\begin{tabular}{|l|l|}
\hline \multicolumn{1}{|c|}{ Gift } & \multicolumn{1}{c|}{ Possible Activity } \\
\hline Teaching & $\begin{array}{l}\text { Teacher in Sabbath School, small groups, Bible studies, } \\
\text { seminars }\end{array}$ \\
\hline Service & Deacon, deaconess, visitation, etc. \\
\hline $\begin{array}{l}\text { Knowledgc } \\
\text { wisdom }\end{array}$ & Resource person for ministry groups, teaching activities, ctc. \\
\hline Exhortation & Pecr counscling, rctreats, youth ministry, support groups, ctc. \\
\hline Discernment & Bible-study groups, Sabbath School class leader, counseling \\
\hline Faith & $\begin{array}{l}\text { Ministry groups that need cncouragement and long-range } \\
\text { planning }\end{array}$ \\
\hline Giving & For regular and special needs \\
\hline Apostleship & Church planting, planning new ministries, etc. \\
\hline Pastoring & Visitation, area spiritual coordinator, small-group chaplain, etc. \\
\hline Evangelism & $\begin{array}{l}\text { Door-to-door ministries, apprenticeship programs, public } \\
\text { meetings }\end{array}$ \\
\hline Mercy & Hospital visitation, community service, prison ministries, etc. \\
\hline Hospitality & $\begin{array}{l}\text { Receptionist/greeting ministry, small-group, community } \\
\text { activities }\end{array}$ \\
\hline Administration & Organizing activities, chairing and managing groups, etc. \\
\hline Missionary & Any activity across ethnic on cultural boundaries, etc. \\
\hline Intercessory prayer & Intercessory-prayer ministries, small-group prayer leader, etc. \\
\hline Assistance & $\begin{array}{l}\text { Church maintenance, deacons, church-office personnel, ministry } \\
\text { in groups }\end{array}$ \\
\hline Leadership & Elder, deacon, committee chairperson, ministry leader, etc. \\
\hline
\end{tabular}


There are also the four basic temperaments: choleric, sanguine, phlegmatic, and melancholy--with combinations of each. The ministry should match members of like personality and temperament to increase a sense of fulfillment. ${ }^{1}$

5. Does the person's experience show where he/she would minister best? Rick Warren says that in his church they consider five areas of the member's experience: "Education, career, spiritual journey, previous ministries, and painful events."2

The "fit" of a potential leader in a specific leadership function takes into account a person's gifts, natural abilities, temperament, skills and passion, and then considers how well he/she will fit into the team. No matter how great the potential of the leader, if he/she cannot play with the team, he/she will not help the church. ${ }^{3}$

Each ministry needs a leader. In some congregations the pastor could divide these spiritual-gifts ministries into four areas with a leader with more experience acting as supervisor for each area-a coordinator of ministries. The coordinator of ministries works closely with the leaders who comprise their ministry area. In this model, the pastor becomes a general coordinator of ministries.

\section{Ongoing Training and Placement}

Training in the use of spiritual gifts and talents does not end after placement. Pastors and coordinators must provide specific local training to give the leaders the tools they need. Maxwell says that "giving responsibility without resources is ridiculous; it is

\footnotetext{
'Johnson, Spiritual Body Building, 59-61.

${ }^{2}$ Warren, 375 .

${ }^{3}$ Maxwell, Developing the Leaders around You, 95.
} 
incredibly limiting."' If the pastors want to prepare strong leaders to be creative and resourceful, they need to provide resources.

There are different kinds of resources. The most basic tools are pieces of equipment that simplify someone's work. Tools, however, include more than equipment. Maxwell calls some tools "developmental tools."2 This means spending time mentoring people in specific areas of need. There are also material resources such as books, videos, and syllabi. Seminars and retreats are also tools that help people to grow and equip them to do the job well.

In this ongoing process of placement, newcomers need to be trained to discover, develop, and use their gifts in ministry. The church needs to provide ministry for them and to motivate them to become involved in ministry. They, too, should be involved in the process of discipleship. Even inactive church members can be taught by the Holy Spirit to use their gifts. As soon as they show interest they need to have an opportunity to work.

\section{Ongoing Development}

Equipping church members to become leaders is the greatest goal of the district pastor. In this process, people are motivated, affirmed, and empowered to use their gifts to build up the body of Christ--the church.

'Ibid., 104.

${ }^{2}$ Ibid., 105.

${ }^{3}$ Ibid., 104. 
Erich Baumgartner says that this process could result in "leadership multiplication." ${ }^{\prime \prime}$ By leadership multiplication the pastor equips and empowers a group of leaders that prepares others to be leaders. In this process of leader multiplication, ordinary people can do extraordinary things: increase the growth potential of church ministry, multiply church outreach without sacrificing quality, allow the district pastor to function as a spiritual leader and equipper, free church members to work in ministry where they are gifted and equipped, and free leaders to lead and reproduce other leaders. ${ }^{2}$ The ultimate results could be improved health of the church and an increased harvest of souls for God's Kingdom.

\section{Motivating}

Everybody needs to be motivated. Charles Schwab says, "I have never seen a man who could do real work except under the stimulus of encouragement and enthusiasm, and the approval of the people for whom he is working." ${ }^{3}$ The question in pastoral circles today is, How are people motivated for volunteer ministry? Malphurs observes: "You can only motivate people when your motivation comes from God."4

'Erich W. Baumgartner, Class outline for MSSN 735 Strategies for Church Growth, Andrews University, Berrien Springs, MI, Winter 1998, "Empowering leadership," section, 7 .

${ }^{2}$ Logan and Short, 156.

${ }^{3}$ Charles Schwab, quoted in Bolb Bilhl, Thirty Days to Confident Leadership (Nashville: Broadman and Holman, 1998), 155.

${ }^{4}$ Aubrey Malphurs, Developing Vision for Ministry in the $21^{\text {st }}$ Century (Nashville: Abingdon, 1990), 26. 
Some activities and attitudes that could be helpful to motivate people for volunteer work are the following:

1. Preaching and personal care: Church members well fed by the preaching sermon and personal care are more susceptible to be motivated.

2. Sense of belonging: People are motivated and commit themselves to a church where they feel wanted. This motivating component is rooted in the innate human need for social relationship. For some people, a sense of belonging is all they need to be motivated. They feel highly motivated in a climate where they sense they are a vital part of the team's mission.

3. Compassion and love: The ultimate motivational force in the universe is love. The love of Jesus in the heart and the sense of God's call are the great strengths that move men and women to service.

4. Recognition: Everyone likes to be recognized. Unfortunately, the task of saying "thank you" to volunteers is neglected by many pastors and churches. Somchow the church needs to plan how to express formally and informally its recognition of those who are working for the Lord.' Giving personal and public appreciation of effort and positive performance is recognition. ${ }^{2}$

5. Rewarding: This element is rooted in the innate human desire for power and material things. Rewards can be "intangible," such as increasing authority, promotion,

'Johnson, Empowering Lay Volunteers, 109.

${ }^{2}$ Norton, Class Notes for CHMN 638. 
time off; honorific or "tangible" such as prizes, ribbons, plaques, certificates, and material things.' All rewards must appeal to unselfish and pure motives for service.

Douglas Johnson gives some strategic steps that the local church can follow regarding commitment, rewards, and motivational events. All could be a source of motivation.

1. An annual commitment scrvice. At the beginning of the year a commitment scrvice can be planned for volunteers who are beginning their jobs and those who want to renew their commitment. The pastor can call them to the front and pray for them. A card could be prepared for this occasion called "My commitment to the service of the Lord."

2. Celebration of service. The end of the year is a good time to plan a special day to affirm and celebrate lay ministry. This special day must be one with a festive atmosphere and give recognition for the work that the volunteers have done. Sabbath would be the best day for this event. The church program should include a special section called "Our People in Ministry." A list of the volunteers and their respective ministries should be included in the bulletin. The church should give each volunteer a concrete token of appreciation. This token can be a certificate, a pin, a new book, or a Bible. ${ }^{2}$

3. Fishing-pool events or a festival of faith. Once every three months, church members could gather for a festival of faith. Church members involved in ministry

${ }^{\mathrm{I} I b i d .}$

${ }^{2}$ Johnson, Empowering Lay Volunteers, 109-110. 
praise the Lord and share experiences and testimonies. Fishing-pool events have two main purposes: (a) to provide an outstanding opportunity to renew the purpose of using gifts to God's scrvice and (b) to recruit inactive people to ministry.

Douglas Johnson sees thesc occasions as a great opportunity to increase each church member's understanding of Christ's call to service and to acquaint the congregation with areas of possible ministry. He also suggests distributing a list of "ministry opportunities," indicating the number of pcople involved and the members needed in various ministry tasks. It is important to make contact with those who complete the interest surveys to discuss possible areas of involvement and a course of training.

\section{Evaluating}

Evaluation, an important element in the equipping process, has sometimes been used in misguided ways--as an instrument to prove rather than improve, or as a weapon against a pastor. This causes frustration for lay leaders instead of new energy for ministry. ${ }^{1}$ Pastors often fear evaluations will reveal painful critiques or weak congregations. Too often these fears are founded in fact. Nevertheless, evaluations are accepted as a necessary instrument. The task of evaluation in itself is worthy of review, conversation, and improvement.

Jill Hudson gives a clear definition and purpose of evaluation in pastoral work.

Evaluation can be considered an ongoing process that strengthens our ministry, giving us the opportunity to reflect periodically on how well we are fulfilling our

'Jill M. Hudson, Evaluating Ministry: Principles and Processes for Clergy and Congregations (Washington, DC: Alban Institute, 1992), 2. 
commitments to Christ, the church, and one another. It helps both clergy and laity redefine their current sense of calling and identifies where they are feeling good about their ministry, what may need more attention, and what can appropriately be put to rest as no longer needed.'

Hudson also presents some advantages of periodic evaluations which should motivate pastors to incorporate them into their pastoral work.

1. Evaluations enlarge the possibility to try new ways, new methods, and to create new avenues of service. Evaluation is an opportunity to discover needs and to satisfy them.

2. Evaluations enlarge the possibility of improving the church's ministry and help the pastor and congregation to measure the feasibility of the goals and the management of the material resources.

3. New goals and directions can be established through evaluation. The process of examining current ministries can lead pastors and laity to the development of new priorities.

4. Evaluations help pastors and church leaders to concentrate their efforts on what is relevant and to emphasize the difference between quantitative and qualitative growth of the church.

5. Evaluations tighten the relationship between pastor and members. They should lead pastors and laity to recognize their strengths and weaknesses and bring them together in a shared ministry of the church. They support one another in seeking new insights to minister each day in better way. ${ }^{2}$

\section{${ }^{1}$ Ibid.}

${ }^{2}$ Ibid., 3-4. 
Every ministry or every branch of service should be evaluated at least once a year. A good time is the last quarter of the year during the general session training. Besides this general annual evaluation, each church ministry needs to produce a monthly report of how the ministry is progressing. This helpful tool aids pastors and the SGCC to evaluate the needs and progress of each ministry. Based on this report, the pastor can establish the order of priorities and training agenda. This kind of evaluation must be seen as an opportunity for the pastor to better serve church leaders, not letting time go by for ministries in trouble.

In some cases, it is productive for the pastor to request a comprehensive review of his/her own ministry for personal assessment and growth. This is not an instrument of despair or self-punishment. The pastor needs to carcfully evaluate the results and, by God's power, improve his/her cffectiveness.

As pastor and congregation are willing to explore prayerfully the effectiveness of ministry together, both can expect growth. Mutually reviewing ministries results in revitalizing the purpose of the church and re-energizing pastors and members. Everyone wants to believe that what they are doing is worthwhile. Regular reviews give the necessary feedback to continue moving forward in confidence that what everyone is doing is important and necessary to build up the body of Christ--the church.

\section{Keeping This Program Alive}

In order to keep the lay members spiritually alive, I suggest seven elements to be considered. 
I. Listening and affirming. The pastor needs to spend time listening and affirming members and church leaders. Affirm their ministry and assure them that their work matters to God.

2. Patience. This program may be a radical change for many church members. Church members may be slow to recognize their ministries. Maxwell states: "Don't be surprised or discouraged if they don't respond with eagerness."' Be patient!

3. Leadership development. New leaders need to be equipped and trained at all levels, and current leaders need to mature. The pastor needs to give them the vision and the resources.

4. The church, an equipping school. Pastoral work within the program needs to transform each congregation into a school. Equipping or teaching may take place in worship services, Bible classes, weekend seminars, training events, and within Christian homes. Ellen White endorses the importance of transforming our churches into equipping schools: "Many would be willing to work if they were taught how to begin. They need to be instructed and encouraged. Every church should be a training school for Christian workers."2 "It is not enough to show how much needs to be done. They must be taught how to labor for the Master." ${ }^{13}$ She further declares that "there should be a well-organized plan for the employment of workers to go into all our churches, large and small, to instruct the members how to labor for the upbuilding of the church and also for

'Maxwell, Developing the Leaders Around You, 70.

${ }^{2}$ Ellen G. White, The Ministry of Healing (Mountain View, CA: Pacific Press, 1942), 149.

${ }^{3}$ White, Gospel Workers, 210. 
unbelievers. It is training, education, that is needed."' She also appeals that "there should be no delay in this well-planned effort to educate the church members." ${ }^{2}$

5. Worship. The pastor needs to make sure that the word is preached and that the worship service each Sabbath nourishes members for the work of ministry. Kim Johnson says that in church worship, especially on Sabbath, teaching and preaching need to be geared more directly to helping church members to be effective in their calling to ministry. The worship service needs to inspire, uplift, and meet the varied needs within the congregation. ${ }^{3}$

6. Small groups. Small groups could be the greatest strategy to keep this program alive. It is a fantastic way to produce Icadership, build a broad base of leadership, and provide support to keep church ministries growing and meeting needs.

These small groups could become the catalysts of spirituality and evangelistic enthusiasm within the church, and cach church member can play a part. ${ }^{4}$

7. Outreach-Evangelism. In order to keep this program alive, evangelism must be the reason of being of every ministry and function of the SDA church. Every ministry is a channel by which the church fulfills its mission and persons are won to Christ. Ministry must focus on winning souls to Jesus. Outreach becomes not only an event but

'White, Testimonies for the Church, 9:117.

${ }^{2}$ Ibid., 9:119.

${ }^{3}$ Adapted from Johnson, Spiritual Body Building, 25.

${ }^{4}$ Mark Finley, "The Way to Adventist Church Growth Syllabus," Lake Union Soul Winning Institute, Chicago, 1980, 18-20. 
also a way of life. The church is a dynamic evangelistic center that prepares men and women to reach people and to make disciples for God's kingdom.

\section{The Great Decision}

The program suggested in this dissertation should lead pastors in Brazil to decide what they really want for their pastorate and for their districts. Johnson points out that the Adventist pastor today can work to build the SDA church in two very different perspectives--an "information model and the glory of God model." The model the pastor adopts will probably be the most important choice he will ever make. The model he chooses will largely determine how he "does church."' Notice the two models of church, as suggested by Johnson.?

TABLE 3

TWO MODELS OF CHURCH

\begin{tabular}{ll}
\hline Information Model (traditional) & Glory-of-God Model (biblical) \\
\hline Pastor reactive & Pastor leader/equipper \\
Spectators & Disciples \\
Professionals & Priesthood of all belicvers \\
Few spiritual gifts & All spiritual gifts \\
Reaping & All needs \\
Programs/media & Relationships \\
Information/task & People \\
\hline
\end{tabular}

The glory-of-God model could be understood as the general emphasis and purpose of this whole program. If the district pastor decides to do pastoral ministry

'Johnson, Spiritual Body Building, 149.

${ }^{2}$ Ibid., 150. 
within the glory-of-God model, the results could be positive. In this scheme building people becomes the key to being a church. The emphasis is not only on what we know but also, more importantly, on who we are. It is broad, biblical, and balanced. The ultimate focus of such a church is to promote among church members a Christian relationship.

The needs of church members and community drive the plans, efforts, and budget. In order to meet the great varicty of people needs, all spiritual gifts available are activated and church members serve in the ministry that they feel gifted for.

The members of the church understand their call to be priests and to minister for the advancement of God's kingdom. Because the emphasis is on everyone being a priest, the goal becomes not just baptisms but producing mature disciples for Christ. Now that the gifts and ministries of the laity are activated, the pastor can become "the specialist God designed as a leader/equipper."' Pastoral ministry can be a more productive and joyful experience. The church experiences integral growth. Pastors and church members will be working hand in hand to build up the body of Christ by doing their ministry for the glory of God.

'Johnson, Spiritual Body Building, 151. 


\section{CHAPTER 6}

\section{SUMMARY, CONCLUSIONS, AND RECOMMENDATIONS}

\section{Summary}

Pastoral work in multi-church districts in Brazil has been a major challenge. Times and circumstances urge us to define roles and change the way many district pastors are doing their job. There is a need for a clear understanding of their roles as spiritual leaders and equippers. Pastors are not going to fulfill the mission of the church by themselves, but the church is a gifted body where each member has privileges and responsibilities to use their gifts to ministry.

Although this program to enhance pastoral work presents concepts and guidelines that can be applied in any district in Brazil, the method utilized to implement this program needs to be adapted to the unique circumstances of each district. The suggestions presented in this study have taken into account common needs of the district pastor in Brazil. District pastors should concentrate pastoral efforts to mobilize laity into a more meaningful ministry aimed at church growth in their own districts.

Mobilizing church laity is important from the perspective of enhancing pastoral work in multi-church districts. It is a great dream of the district pastor to have every member involved in some area of the church ministry. The realization of this dream involves willingness from the pastor to pay the price, by assuming his role as spiritual 
leader and equipper. The principal task of those set apart by ordination for pastoral ministry is to lead and "to equip the saints for the work of ministry, for building up the body of Christ" (Eph 4:12).

The biblical doctrines of the priesthood of all believers and spiritual gifts may be the key factor to mobilize church members to get involved in church ministry. Every Christian is a priest with privileges and responsibilities. All Christians together constitute a priestly body whose business is the expression of Christ's priesthood with the task to carry out the mission of the church.

The church needs the Holy Spirit to accomplish its task. The Holy Spirit's ministry includes spiritual gifts. These gifts make the body grow. Spiritual gifts are action tools which the Holy Spirit gives the church. The correct and wise use of spiritual gifts will bring unity to all believers in the church. The doctrine of spiritual gifts is important to keep the church mission alive. It lightens the burden of the pastor and affirms the priesthood of all believers. The subject of spiritual gifts has greater significance when considered in the context of the ministry of all believers.

Paul uses the human body as an analogy of how spiritual gifts combine in different persons to accomplish the advancement of the kingdom. Spiritual gifts tie together internal spiritual growth and outward numerical expansion. Spiritual gifts assigned a person by the Holy Spirit may or may not match that person's natural talents, depending on the Holy Spirit's assignment. It seems clear that the Holy Spirit uses such gifts to bring personal growth and to build up the body of Christ--the church.

As part of this program to enhance pastoral work in multi-church district, the development of a plan is vital in this process to mobilize laity into ministry and empower 
them to become active participants in the church's ministry and to become radical disciples of Jesus Christ. To cstablish this program, pastors need to assume their role as spiritual leaders and equippers of the church. In the planning process pastors prepare the church by creating an appropriate climate, developing a mission statement, and redefining the concept of ministry.

The mobilization of laity into ministry depends in great measure on the pastor's ability to recognize that they cannot do all the work alone and that they need to cmpower others to help with the work. This is achicved during the equipping phase of the program during which pastors teach the biblical concept of the pricsthood of all believers and help members discover, develop, and utilize gifts designed for various ministries. The key ingredients for developing this program are to follow Jesus's model in preparing His disciples and exerting pastoral effort towards developing ministry leaders for a variety of ministries in the church.

\section{Conclusions}

Some of the conclusions rising out of this dissertation have been:

1. The doctrines of spiritual gifts and the priesthood of all believers need to be understood. A careful study will bring renewal in the church.

2. The mobilization of laity to work for the church should be based on helping them understand their call to be priests and to use their spiritual gifts. Utilizing one's spiritual gifts is part of a Christian's preparation for eternity. Failure to utilize one's gifts also results in eternal consequences. 
3. The role of the pastor is to release the potential gifts and talents by helping the church members to discover, develop, and use their spiritual gifts in meaningful ministry. This will result in qualitative and quantitative growth. Pastors and church members will benefit; they will discover new avenues of service and above of all God will be honored.

4. When spiritual gifts match the person's ministry in the church, and members are equipped to do their job, a more joyful and effective experience will result. The quality of church ministry will improve. Members will experience personal growth in Christ and God will add His blessing to their congregations with an influx of converts. Because the church has quality, He can trust it with quantity. It is a safe environment for new members and the church can become strong collective witnesses for Jesus.

5. A program of mobilizing, equipping, training, and preparing laity for ministry and pastoral work according to members' gifts, which concentrate on the formation of church leaders, is valuable and of great advantage for the district pastor and church members. It provides effectiveness in the fulfillment of their role and functions. Such a program can be a catalyst for the church to experience both spiritual and numerical growth.

\section{Recommendations}

Several recommendations are the outgrowth of this research to help develop a program to enhance pastoral work in multi-church districts in Brazil.

1. The unions and conferences should offer effective, continual education programs and support them with the necessary materials to aid district pastors to improve 
their leadership skills, and creative resources to help them train church leaders and foster integral church growth.

2. Once a year the union or conference should send a book or syllabus that can contributc to improve some aspect of pastoral life or ministry.

3. The two seminaries in Brazil should add to the curriculum some subjects presented in this project, such as pastoral leadership, pastoral roles, the doctrine of spiritual gifts, and the training of lay leaders for church growth.

4. The departments of the unions and conferences should work to meet the needs of district pastors. Instead of promoting only thcir own departments, pastors who occupy such departments should be well prepared and gifted to prepare materials that can be tools for the district pastors in their major task of "equipping the saints for ministry."

5. With the support of their respective unions, each local conference should establish a permanent training center so both pastors and church leaders can participate in effective teaching and training according to their regional needs.

6. Conferences and the local churches should create an annual budget for the specific purpose of helping district pastors to buy materials or equipment that could facilitate the task of equipping and teaching.

7. The program suggested here should be improved, adapted, and widely used wherever needed for the benefit of both district pastor and the local church. 


\section{BIBLIOGRAPHY}

Alcorn, Wallace A. "The Biblical Concept of Discipleship as Education for Ministry." Ph.D. dissertation, New York University School of Education, 1974.

Anderson, Ray S. "A Theology for Ministry." In Theological Foundations for Ministry, ed. R.S. Anderson, 7-12. Grand Rapids: Eerdmans, 1979.

. The Soul of Ministry. Louisville, KY: Westminster John Knox, 1977.

Arn, Win. The Pastor's Church Growth Handbook. Pasadena, CA: Church Growth, 1979.

Arnold, Jeffrey. Seven Traits of a Successful Leader. Colorado Springs, CO: NavPress, 1997.

Arnold, Jeffrey, and Stephanic Black. The Big Book on Small Groups. Downers Grove, IL: InterVarsity, 1992.

Autry, James A. Love and Profit: The Art of Caring Leadership. New York: Morrow, 1991.

Barna, George. The Frog in the Kettle. Ventura, CA: Regal, 1990.

- The Power of Vision. Ventura, CA: Regal, 1992.

- User Friendly Churches. Ventura, CA: Regal, 1991.

Baumgartner, Erich W. Course outline for MSSN 735 Strategies for Church Growth. Andrews University, Berrien Springs, MI, 1998.

- "Towards a Model of Pastoral Leadership for Church Growth in GermanSpeaking Europe." Ph. D. dissertation, Fuller Theological Seminary, 1990.

Bennis, Warren, and Burt Nanus. Leaders: Strategies for Taking Charge. New York: Harper and Row, 1985. 
Beyer, Hermann W. "Diakoneō, Diakonia, Diakonos." Theological Dictionary of the New Testament. 10 vols. Grand Rapids: Eerdmans, 1964-1974.

Bilhl, Bolb. Thirty Days to Confident Leadership. Nashville: Broadman and Holman, 1998.

Bobgan, Martin, and Deidre Bobgan. Competent to Minister: The Biblical Care of Souls. Santa Barbara, CA: EastGate, 1996.

Bookes, Dean F. "Growth in Australian Churches." D.Min. dissertation, Fuller Theological Seminary, 1990.

Bresee, Floyd. "Keep What You Reap." Ministry, April, 1990, 23. . "Should You Try Expository Preaching?" Ministry, September, 1991, 25.

Burrill, Russell. Revolution in the Church. Fallbrook, CA: Hart Research Center, 1993.

Christian, Gerald. "A Strategy for Revitalization of Congregational Life through Mission Clarification and the Training of Lay Members in Discipleship." D.Min. disscrtation, Andrews University, Berrien Springs, MI, 1987.

Cho, Paul Yonggi. Successful Home Cell Groups. Plainfield, NJ: Logos International, 1981.

Clinton, J. Robert. The Making of a Leader. Colorado Springs, CO: NavPress, 1988.

Coleman, Lucien E. "The Ministry of Teaching." In Formation for Christian Ministry, ed. Anne Davis and Wade Rowatt, Jr., 222-225. Louisville, KY: Review and Expositor, 1988.

Coleman, Robert E. The Master Plan of Evangelism. Grand Rapids: Fleming H. Revell, 1996.

Conn, Charles W. A Balanced Church. Cleveland, TN: Pathway, 1975.

Cousins, Don, Leith Anderson, and Arthur DeKruyter. Mastering Church Management. Portland, OR: Multnomah, 1990.

Covey, Stephen R. The 7 Habits of Highly Effective People. New York: Fireside, 1990.

Crane, Barry N. "Teamwork: The Lay Leader's Guide to Church Growth." D.Min. dissertation, Fuller Theological Seminary, 1992.

Cress, James A. "How to Destroy Your Leadership.” Ministry, January 1996, 30. 
Dale, Robert. Leadership for a Changing Church. Nashville: Abingdon, 1998.

Davis, Anne, and Wade Rowatt, Jr. Formation for Christian Ministry. Louisville, KY: Review and Expositor, 1983.

de Oliveira, Enoch. "The Universal Priesthood." Ministry, 8 August 1972, 31-32.

Dederen, Raoul. "The Priesthood of All Believers." In Women in Ministry: Biblical and Historical Perspectives, ed. Nancy Vyhmeister, 9-26. Berrien Springs, MI: Andrews University Press, 1998.

Diehl, William E. Ministry in Daily Life: A Practical Guide for Congregations. New York: Alban Institute, 1996.

Douglas, Walter. Class notes for CHIS 688 Contemporary Trends. Andrews University, Berrien Springs, MI, Spring 1998.

Drucker, Peter F. Leadership Handbook of Management and Administration. Edited by James D. Berkley. Grand Rapids: Baker, 1994.

Dudley, Roger L., and Des Cummings, Jr. Adventures in Church Growth. Washington, DC: Review and Herald, 1983.

Duran, Francy. "Spiritual Nurture in the Local Seventh-day Adventist Congregation Through the Spiritual Gifts of Prophecy and Shepherding." Ph.D. dissertation, Andrews University, Berrien Springs, MI, 1996.

Eastwood, Charles C. The Royal Priesthood of the Faithful: An Investigation of the Doctrine from Biblical Times to the Reformation. Minneapolis: Augsburg, 1963.

Easum, Bill. Sacred Cows Make Gourmet Burgers: Ministry Anytime, Anywhere, by Anyone. Nashville: Abingdon, 1995.

Edwards, Rex D. Every Believer a Minister. Silver Spring, MD: General Conference of SDA, 1995.

Ellas, John W. Measuring Church Growth. Houston, TX: Center for Church Growth, 1997.

Elliston, Edgar J. Home Grown Leaders. Pasadena, CA: William Carey Library, 1992.

Engelkemier, Joe. Class notes for CHMN 616 Spirituality in Ministry. Andrews University, Berrien Springs, MI, Fall 1997. 
Engen, Charles Van. God's Missionary People: Rethinking the Purpose of the Local Church. Grand Rapids: Baker, 1991.

Engstrom, Ted W. The Making of a Christian Leader. Grand Rapids: Zondervan, 1976.

Erdahl, Lowell O. Ten Habits for Effective Ministry. Minneapolis: Augsburg Fortress, 1996.

Erdman, Charles R. The Work of the Pastor. Philadelphia: Westminster, 1924.

Fackre, Gabricl. "Christ's Ministry and Ours." In The Laity in Ministry: The Whole People of God for the Whole World, ed. George Reck and John S. Hoffman, 113-119. Valley Forge, PA: Judson, 1984.

Faust, David. Growing Churches, Growing Leaders. Joplin, MO: College, 1994.

Finlcy, Mark A. "Vital Signs of a Healthy Church." Ministry, May 1982, 5-7.

"The Way to Adventist Church Growth," Chicago: Lake Union Soul Winning Institute, 1980.

Fisher, David. The $21^{\text {st }}$ Century Pastor: A Vision Based on the Ministry of Paul. Grand Rapids: Zondervan, 1996.

Fortune, Don, and Katie Fortune. Discover Your God-Given Gifts. Grand Rapids: Chosen, 1996.

Fowler, James W. Faith Development and Pastoral Care. Theology and Pastoral Care Series. Philadelphia: Fortress, 1987.

Fowler, John W. Adventist Pastoral Ministry. Boise, ID: Pacific Press, 1990.

Fulenwider, Ray. The Servant-Driven Church: Releasing Every Member for Ministry. Joplin, MO: College, 1997.

Galloway, Dale E. 20/20 Vision: How to Create a Successful Church. Portland, OR: Scott, 1986.

General Conference of Seventh-day Adventists. Seventh-day Adventist Minister's Manual. Silver Spring, MD: General Conference of Seventh-day Adventists, Ministerial Assn., 1992.

George, Carl F. Prepare Your Church for the Future. Grand Rapids: Fleming H. Revell, 1996. 
George, Carl F., and Robert E. Logan. Leading and Managing Your Church. Old Tappan, NJ: Fleming H. Revell, 1987.

Gibbs, Eddie. I Believe in Church Growth. Grand Rapids: Eerdmans, 1981.

Greenwalt, Glen. "A Priesthood of All Believers: Neither Republic nor Hierarchy." Spectrum 18 (October 1987): 43-49.

Hall, Eddy, and Gary Morsch. The Lay Ministry Revolution. Grand Rapids: Baker, 1995.

Hadaway, C. Kirk. Church Growth Principles: Separating Fact from Fiction. Nashville: Broadman, 1991.

Harris, John C. Stress, Power, and Ministry. Washington, DC: Alban Institute, 1977.

Harvey, James E. Who's in Charge? Leadership Skills for Clergy and Others in Ministry. Chicago: Loyola, 1996.

Hoffman, Reynolds. "Planning a Sermonic Year." Ministry, December 1978, 8-9.

Hudson, Jill M. Evaluating Ministry: Principles and Process for Clergy and Congregations. Washington, DC: Alban Institute, 1992.

Hull, Bill. Seven Steps to Transform Your Church. Grand Rapids: Fleming H. Revell, 1993.

Hull, William B. “The Pastor: Ministry or Administrator?" Ministry, May 1978, 8-9.

Hull, William E. "Commentary on John 10." The Broadman Bible Commentary. 12 vols. Edited by Clifton J. Allen. Nashville: Broadman, 1970.

Hunt, Earl G., Jr. Evangelism for a New Century. Nashville: Discipleship Resources, 1994.

Hunter, Kent R. Your Church Has Personality. Nashville: Abindgon, 1985.

Hunter, George G., III. To Spread the Power of Church Growth in the Wesleyan Spirit. Nashville: Abingdon, 1988.

Hybels, Bill. Too Busy Not to Pray. Downers Grove, IL: InterVarsity, 1988.

Jackson, Walter C. "The Minister as Leader." In Formation for Christian Ministry, ed. Anne Davis and Wade Rowatt, Jr., 170-173. Louisville, KY: Review and Expositor, 1981. 
. "Church Ministry Leadership." In Preparing for Christian Ministry: An Evangelical Approach, ed. David P. Gushee and Walter C. Jackson, 170-179. Wheaton, IL: Victor, 1996.

Johnson, Douglas W. Empowering Lay Volunteers. Edited by Lyle E. Schaller, Nashville: Abingdon, 1991. . Vitality Means Church Growth. Nashville: Abingdon, 1989.

Johnson, Kim A. Spiritual Body Building. Silver Spring, MD: Gencral Conference of SDA, 1997.

Jones, Bruce W. Ministerial Leadership in a Managerial World. Wheaton, IL: Tyndale, 1988.

Jones, Clifford. Class notes for CHMN 527 Church Leadership and Administration. Andrews University, Berrien Springs MI, July 1998.

Kilcher, Douglas R. "The Minister as an Equipper." In The Adventist Minister, ed. C. R. Holmes and D. R. Kilcher, 99-102. Berrien Springs, MI: Andrews University Press, 1991.

Knowles, George E. How to Hclp Your Church Grow. Silver Spring, MD: General Conference of SDA, 1997.

Kilmann, Ralph H., and Teresa Joyce Covin. Corporate Transformation: Revitalizing Organizations for a Competitive World. San Francisco: Jossey-Bass, 1988.

Lewis, Phillip V. Transformational Leadership: A New Model for Total Church Involvement. Nashville: Broadman and Holman, 1996.

Lindgren, Alvin J., and Norman Shawchuck. Let My People Go: Empowering Laity for Ministry. Nashville: Abindgon, 1980.

Logan, Robert E. Beyond Church Growth. Tarrytown, NY: Fleming H. Revell, 1989.

Logan, Robert E., and Larry Short. Mobilizing for Compassion. Grand Rapids: Fleming H. Revell, 1994.

Luther, Martin. The Misuse of the Mass. Luther's Works. Vol. 13 Saint Louis, MO: Concordia, 1955-1986.

MacArthur, John, Jr. The Church the Body of Christ. Grand Rapids: Zondervan, 1974. 
MacCarty, Skip. Class outline for EDRE 676 Family Ethics: Family Life Conference. "Using Your Time to Accomplish What's Most Important." Andrews University, August 1996.

Macrae, William. The Dynamic of Spiritual Gifts. Grand Rapids: Zondervan, 1976.

Matos, Jonas E. A. "A Lay-leadership Training Program for the Seventy-day Adventist Church in Brazil." D.Min. dissertation, Andrews University, 1997.

Malphurs, Aubrey. Developing Vision for Ministry in the $21^{\text {st }}$ Century. Nashville: Abindgon, 1990.

. Planting Growing Churches for the $21^{\text {st }}$ Century. Grand Rapids: Baker, 1992. . Values-Driven Leadership. Grand Rapids: Baker, 1996.

Mattingly, Keity. "Laying on of Hands in Ordination." In Women in Ministry: Biblical and Historical Perspective, ed. Nancy Vyhmeister, 59-74. Berrien Springs, MI: Andrews University Press, 1998.

May, F. J. "The Book of Acts and Church Growth." D.Min. dissertation, Fuller Theological Seminary, 1988.

Mawhinney, Bruce. Preaching with Freshness. Grand Rapids: Kregel, 1997.

Maxwell, John C. Be a People Person. Wheaton, IL: Victor, 1989.

. Developing the Leader Within You. Nashville: Thomas Nelson Publisher, 1993.

. Developing the Leaders Around You. Nashville: Thomas Nelson Publishers, 1995.

McIntosh, Gary L. The Exodus Principle. Nashville: Broadman and Holman, 1995.

McMillan, Len. "Feed My Different Sheep." Ministry, January 1997, 20-22.

Means, James E. Effective Pastors for the New Century. Grand Rapids: Baker, 1993.

. Leadership in Christian Ministry. Grand Rapids: Baker, 1990.

Miller, Calvin. The Empowered Leader: 10 Keys to Servant Leadership. Nashville: Broadman and Holman, 1995. 
Miller, J. Keith. A Hunger for Healing: The Twelve Steps as a Classical Model for Christian Growth. San Francisco: Harper, 1992.

Mullins, Jim. "Prayer: The Continuing Response." In Maps and Models for Ministry, ed. David Whitelaw, 60-76. San Diego, CA: Point Loma Press, 1996.

Nanus, Burt. Visionary Leadership: Creating a Compelling Sense of Direction for Your Organization. San Francisco: Josscy-Bass, 1982.

Nichol, Francis D., ed. Seventh day Adventist Bible Commentary. 7 vols. Washington, DC: Review and Herald, 1980.

Newman, David. Class notes for CHMN 623 Innovative Evangelism. Andrews University, Berrien Springs, MI, August 1998.

Norton, Ricardo. Class notes for CHMN 638 Seminar in Leadership. Andrews University, Berrien Springs, MI, Fall 1997.

Class notes for CHMN 664 Equipping Lay Leaders for Church Growth. Andrews University, Berrien Springs, MI, Spring 1998.

Oden, Thomas C. Pastoral Theology: Essentials of Ministry. San Francisco: Harper and Row, 1983.

Ogden, Greg. The New Reformation: Returning the Ministry to the People of God. Grand Rapids: Zondervan, 1990.

Olsen, V. Norskov. Myth and Truth: Church, Priesthood and Ordination. Riverside, CA: Loma Linda University Press, 1990.

Oosterwal, Gottfried. "Every Member a Minister?” Ministry, February 1980, 5-7.

Peters, Tom, and Nancy Austin. A Passion for Excellence. New York: Random, 1985.

Proctor, Samuel D., and Gardner C. Taylor. We Have This Ministry: The Heart of the Pastor's Vocation. Valley Forge, PA: Judson, 1996.

Qualben, Lars. A History of the Christian Church. New York: Thomas Nelson and Sons, 1942.

Rainer, Thom S. The Book of Church Growth: History. Theology and Principles. Nashville: Broadman and Holman, 1993.

Richards, H.M.S. Radio Sermons. Washington, DC: Review and Herald, 1952. 
Richards, Lawrence O. Expository Dictionary of Bible Words. Grand Rapids: Zondervan, 1991. S.v. "Servant," "Gifts/Gifts."

Richards, Lawrence O., and Gilbert R. Martin. Lay Ministry: Empowering the People of God. Grand Rapids: Zondervan, 1981.

Rice, Howard. The Pastor as Spiritual Guide. Nashville: Upper Room, 1988.

Rock, Calvin B. Church Leadership: A Call to Virtuc. Boise, ID: Pacific Press, 1990.

Sahlin, Monte. Sharing Our Faith with Friends without Losing Either. Washington, DC: Review and Herald, 1990.

Sanders, J. Oswald Spiritual Lcadership. Updated ed. Chicago: Moody, 1994.

Schaller, Lyle E. Getting Things Done. Nashville: Abingdon, 1986.

- The Multiple Staff and the Larger Church. Nashville: Abingdon, 1980.

. The Senior Minister. Nashville: Abingdon, 1989.

Schawchuck, Norman, and Gustave Rath. Benchmarks of Quality in the Church: 21 Ways to Continuously Improve the Content of Your Ministry. Nashville: Abingdon, 1994.

Schuller, Robert. Your Church Has Real Possibilities. Glendale, CA: Regal, 1974.

Schwarz, Christian A. Natural Church Development: A Guide to Eight Essential Qualities of Health Churches. Carol Stream, IL: Church Smart Resources, 1996.

Seventh-day Adventist Encyclopedia. 1996 ed. S.v. "Priesthood of All Believers."

Seventh-day Adventist Church Manual. $15^{\text {th }}$ ed. Hagerstown, MD: Review and Herald, 1995.

Shelley, Marshall. Well-Intentioned Dragons: Ministering to Problem People in the Church. Leadership Library, 1. Carol Stream, IL: Christianity Today, 1985.

Smith, Paul R. "The Methods of Selected British Pastors Evaluated in the Light of the New Testament and Ellen G. White for Their Usefulness to the Seventh-day Adventist Church." D.Min. dissertation, Andrews University, 1992.

Spader, Dann, and Gary Mayes. Growing a Healthy Church. Chicago: Moody, 1991. 
St. Clair, Barry. Leadership: Equipping Young Workers to Lead Students to Maturity in Christ. Wheaton, IL: Victor, 1985.

Staples, Russell, L. "A Theological Understanding of Ordination." In Women in Ministry: Biblical and Historical Perspectives, ed. Nancy Vyhmeister, 135-154. Berrien Springs, MI: Andrews University Press, 1998.

Steinbron, Melvin J. Can The Pastor Do It Alone? Ventura, CA: Regal, 1987.

Stott, John. The Contemporary Christian. Downers Grove, IL: InterVarsity, 1992.

Timm, Alberto Ronald. "Priesthood of Christ and of All Believers According to Martin Luther." Term paper, Adventist Heritage Center, Andrews University, Berrien Springs, MI, May 1990.

Taylor, Richard S. Principles of Pastoral Success. Grand Rapids: Francis Asbrury, 1989.

Vine, W. E. An Expository Dictionary of New Testament Words. 5 vols. Westwood, NJ: Fleming H. Revell, 1952.

Vyhmeister, Nancy J. Class notes for MSSN 560 Mission to the World. Andrews University, Berrien Springs, MI, Summer 1997.

Wagner, C. Peter. Leading Your Church to Growth. Ventura, CA: Regal, 1986. . The Prayer Shield: How to Intercede for Pastors, Christian Leaders, and Others on the Spiritual Front Lines. Ventura, CA: Regal, 1992. . Strategies for Church Growth. Ventura, CA: Regal, 1989. - Your Church Can Grow. Glendale, CA: Regal, 1976.

- Your Spiritual Gifts Can Help Your Church Grow. Ventura, CA: Regal, 1994.

Warren, Rick. The Purpose-Driven Church. Grand Rapids: Zondervan, 1995.

Weiser, A. "Diakoneō," Exegetical Dictionary of the New Testament. ed. Horst Balz and Gerhard Schneider, Grand Rapids: Eerdmans, 1990. 1:302.

White, Ellen G. The Acts of the Apostles. Boise, ID: Pacific Press, 1989. . Christian Service. Hagerstown, MD: Review and Herald, 1983. . Christ's Object Lessons. Washington, DC: Review and Herald, 1941. 
. The Desire of Ages. Mountain View, CA: Pacific Press, 1940.

. Evangelism. Washington, DC: Review and Herald, 1974.

Gospel Workers. Washington, DC: Review and Herald, 1915.

20 .

"The Lord's Working Force." The Review and Herald, September 11, 1913,

The Ministry of Healing. Mountain View, CA: Pacific Press, 1942.

- Testimonies to Ministers and Gospel Workers. Mountain View, CA: Pacific Press, 1962.

. Testimonies for the Church. 9 vols. Mountain View, CA: Pacific Press, 1948.

Wiersbe, Warren, and David Wiersbe. Ten Power Principles for Christian Service.

Grand Rapids: Baker, 1997.

Williams, Dennis E., and Kenneth O. Gangel. Volunteers for Today's Church: How to Recruit and Retain Workers. Grand Rapids: Baker, 1993.

Wiseman, Neil B. Leadership: A Leadership Development Strategy for Church Growth. Kansas City, MO: Beacon Hill, 1979.

Wittenburg, Irmtraut. "Europe's Dream: The Priesthood of All Believers." Spectrum 20 (December 1989): 27-28.

Youssef, Michacl. The Leadership Style of Jesus. Wheaton, IL: Victor, 1986.

Zackrison, James W. Practical Spiritual Gifts. Boise, ID: Pacific Press, 1996.

. "Spiritual Gifts." Adult Sabbath School Lesson, January-March 1997.

Zvandasara, Nkosivabo Z. Leading the Leader. Berrien Springs. MI, Lesley Books, 1997. 
NAME: Paulo Cesar Nogueira

DATE OF BIRTH: 25 Janeiro 1960

PLACE OF BIRTH: Conchal, São Paulo, Brazil

WIFE: Nadia Pereira Nogueira

CHILDREN: Ellen Nogucira

Lincoln Nogueira

CREDENTIAL: Ordained a Seventh-day Adventist Minister, Central

Conference São Paulo, 15 February 1988

EDUCATION:

1983 Bachelor of Arts in Theology, Institute Adventista de Ensino,

Sao Paulo, Brazil

1988 Bachelor of Pedagogy, Faculdade de Filosofia Ciências c Letras, Jales, São Paulo, Brazil

1997 Master of Divinity (equivalency), Andrews University, MI, USA

1999 Doctor of Ministry, Andrews University, MI, USA

DENOMINATIONAL SERVICE:

1984-1987 District Pastor in Fernandopolis, São Paulo, Brazil 1988-1990 District Pastor in Pirassununga in São Paulo, Brazil 1991-1993 District Pastor in Limeira, São Paulo, Brazil

1994-1995 Evangelist in Central Conference São Paulo, Brazil 